\title{
WANDERING WIVES OR FOREIGN FILLIES? \\ The Women of ARchaic Greek Colonisation
}

\section{By Harriet Kerr}

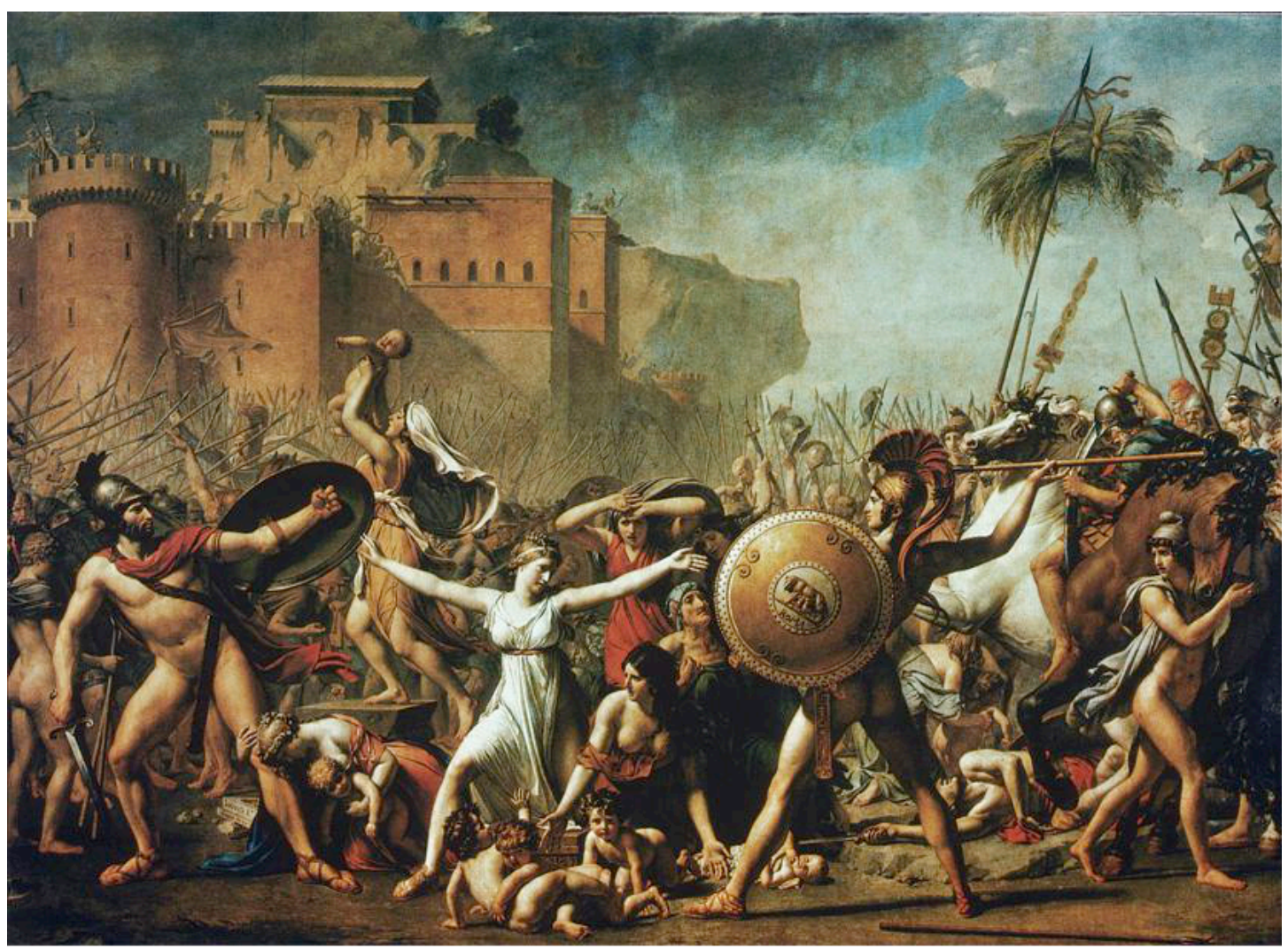

Jacques-Louis David, 'The Intervention of the Sabine Women', 1799, oil on canvas, 385 x $522 \mathrm{~cm}$, Musée du Louvre.

A thesis submitted to Victoria University of Wellington in fulfilment of the requirements for the degree of Master of Arts in Classics

Victoria University of Wellington 
Cover image sourced: ARTstor Slide Gallery: ARTSTOR_103_41822001085339, http://library.artstor.org/library/secure/ViewImages?id=8CJGczI9NzldLS1 WEDhzTnkrX3gqdVB6 eSw\%3D\&userId=gDhPcjIh\&zoomparams, accessed 11/02/2013 


\begin{abstract}
Greek colonisation in the archaic period encompassed an enormous geographical area. But for all its prevalence, the textual evidence is limited in both quantity and quality and the archaeological evidence goes only some way towards helping decipher social change and ethnicity. These issues become even more apparent when considering the position of women in the new city foundations. Did Greek colonists take their own wives with them to their new homes? Were Greek women sent out at a later date once the colony had become established? Did Greek colonists intermarry with indigenous women on arrival? Or did something else happen, including a mix of these options? The weight of scholarly opinion currently falls in favour of intermarriage, though frequently little evidence is proffered to support this view. This thesis focuses on this hypothesis and examines the evidence (or lack thereof) to support this conclusion.

Chapter One examines the problems associated with archaic Greek colonisation generally, particularly those issues connected with the 'language of colonisation'. The study of Greek colonisation has been complicated by imprecise and ambiguous terminology, which frequently draws comparison with more modern (although altogether different) instances of the phenomenon. A major repercussion of this is the tendency to overlook both women and any indigenous peoples. The opening chapter also examines the various reasons behind the foundation of colonies, as well as the different types of settlements, so that an assessment can be made as to whether Greek women might have been more likely to accompany colonising expeditions in some instances over others. Chapter Two looks at the concept of intermarriage more closely and assesses Greek attitudes towards foreign women. It also evaluates the evidence typically called upon by scholars to argue for and against intermarriage in Greek colonisation. Chapter Three assesses the evidence for the presence of women in ten different colonies. Presented roughly in chronological order, these colonies were selected for their geographical scope, covering different regions from the Western Mediterranean, Magna Graecia, North Africa, and the Black Sea. This discussion explores both the literary and archaeological evidence (where possible) for each of these colonies and assesses the potential for intermarriage. This thesis demonstrates that broad conclusions about intermarriage as a widespread practice are unsustainable and concludes that colonisation in the archaic period cannot be considered a uniform phenomenon.
\end{abstract}




\section{TABle OF CONTENTS}

Acknowledgements ...................................................................................................................... 4

Abbreviations ......................................................................................................................5 5

Introduction ..........................................................................................................................6 6

Chapter One - The Prolegomena: Women and Greek Colonisation ..................... 10

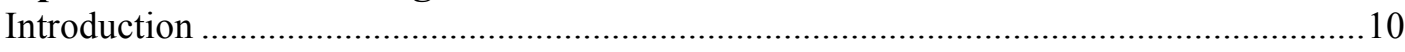

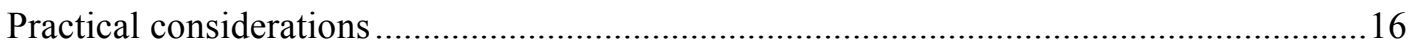

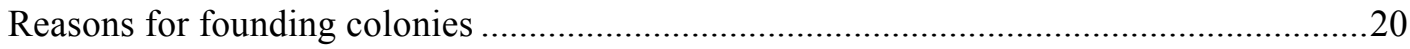

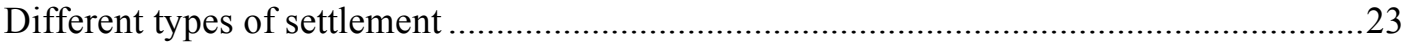

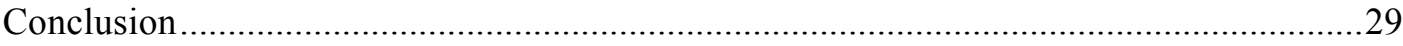

Chapter Two - Intermarriage: A Normal Practice?................................................. 31

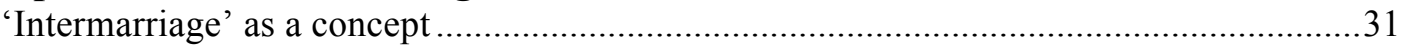

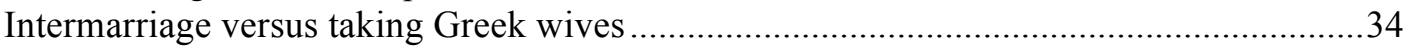

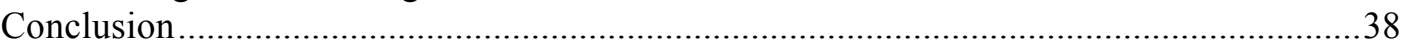

Chapter Three - A Survey of Selected Greek Colonies: Greek Wives or

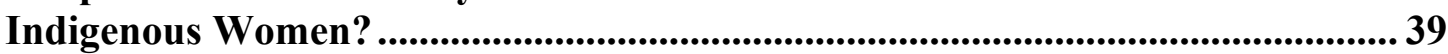

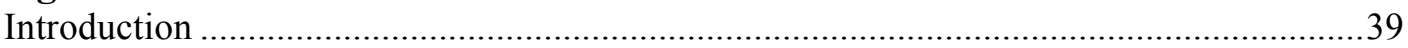

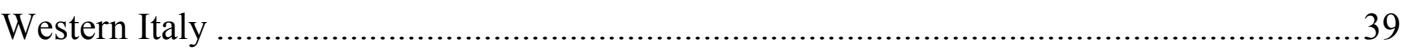

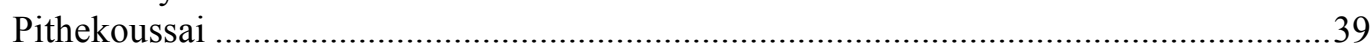

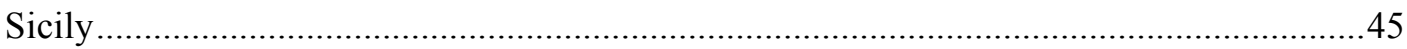

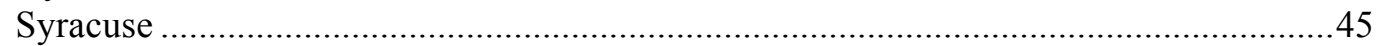

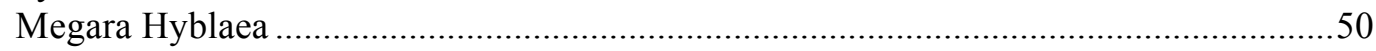

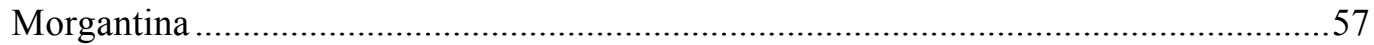

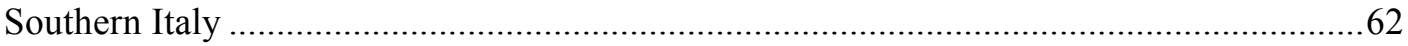

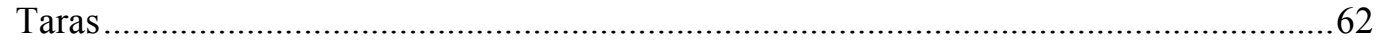

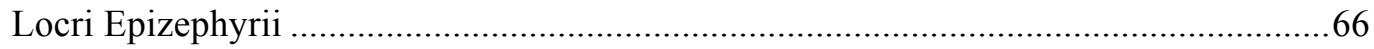

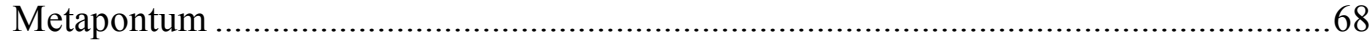

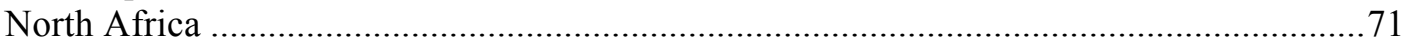

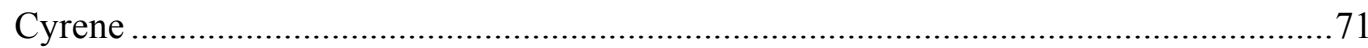

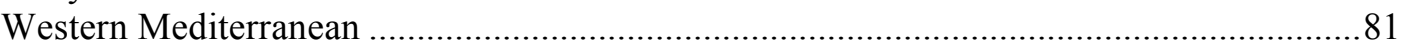

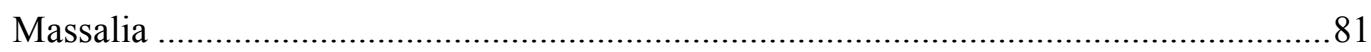

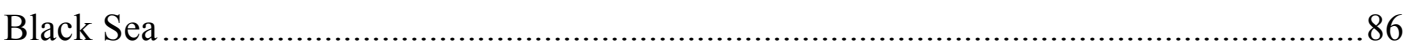

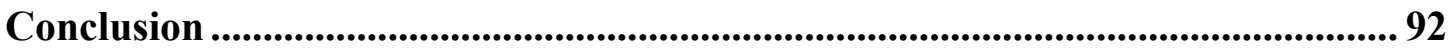

Appendix 1 - Figures............................................................................................ 99

Bibliography ....................................................................................................... 107 


\section{ACKNOWLEDGEMENTS}

It's a well-recognised fact that writing a thesis is a challenging task. A few people deserve special mention here for their help and support at various stages along the way.

I'm grateful for the guidance and expertise of my supervisor, Professor Matthew Trundle.

Thanks to the Classics Department at Victoria University of Wellington, for their support, feedback, and encouragement: in particular, Dr Diana Burton, for going above and beyond, and dedicating hours of her time to help with Greek; Dr Judy Deuling, for her help with fibulae; Chris de L'isle, for always having or finding answers to my (almost) endless conundrums; and Alex Wilson, for help on all things technological. I'm also grateful for the advice, assistance, and moral support of Emily Simons, Geoff Ardell, Jess Casbolt, Dan Knox, and Dan Diggins.

Thanks to Victoria University of Wellington for providing financial support in the form of a Master's Scholarship, and a research grant to attend ASCS 34 in Sydney.

Finally, thanks to my parents, Jenny and Max, not only for their years of proofreading, but also for their unwavering support and encouragement. 


\section{AbBreviations}

CPS: Rosenbaum, E. (1960) A Catalogue of Cyrenaican Portrait Sculpture, London: Oxford University Press.

$I G$ : Lewis, D., Jeffery, L., Erxleben, E. \& Hallof, K. (eds) (1981, 1994, 1998) Inscriptiones Graecae I: Inscriptiones Atticae Euclidis anno anteriores, Berlin: Berlin-Brandenburgische Akademie der Wissenschaften, $3^{\text {rd }}$ ed.

LSJ: Liddell, H. G. \& Scott, R. (1968) A Greek-English Lexicon, Oxford: Claredon Press, $9^{\text {th }}$ ed, revised by Henry Stuart Jones.

ML: Meiggs, R. \& Lewis, D. (eds) (1969) Selection of Greek Historical Inscriptions to the end of the Fifth Century BC, Oxford: Claredon.

OCD: Hornblower, S. \& Spawforth, A. (2012) The Oxford Classical Dictionary, Oxford: Oxford University Press, $4^{\text {th }}$ ed. (unless otherwise specified as being a different edition).

OGIS: Dittenberger, W. (1903-05) Orientis Graeci Inscriptiones Selectae, Leipzig: Herzel.

OLD: Glare, P. G. W. (1968) Oxford Latin Dictionary, Oxford: Oxford University Press.

SEG: Supplementum Epigraphicum Graecum. 


\section{INTRODUCTION}

"The historian who tries to recover the facts about Greek colonization in the archaic period is confronted by many problems." father of Greek colonisation studies, ${ }^{2}$ in 1981-82. These problems include a limited number of written sources and unreliable, sometimes contradictory, archaeological evidence. The difficulties increase, however, when the position of women in these colonies is considered. Did Greek colonists take their own wives with them to their new homes? Were Greek women sent out at a later date once the colony had become established? Did Greek colonists intermarry with indigenous women on arrival? ${ }^{3}$ Or did something else happen, including a mix of these options? In the second half of the twentieth century and continuing into the twenty-first, the weight of the scholarly opinion supports the view that only men founded colonies and therefore intermarried after arrival. This thesis focuses on this hypothesis and examines the evidence (or lack thereof) to support this conclusion.

The chronological and geographical scope of archaic Greek colonisation is often unspecific and accordingly there is little consensus among scholars about it. This thesis encompasses the period of the eighth to sixth centuries BC. Geographically, Greek colonisation reached almost to the end of the known world. Previous studies of Greek colonisation often limit their examinations to a single region, most commonly the 'Western Greeks' of Magna Graecia. ${ }^{4}$ For a more rounded discussion, this thesis endeavours to examine colonies ranging from the Western Mediterranean to the Black Sea (see Figure 1). The importance of these archaic

\footnotetext{
${ }^{1}$ Graham (1981-82) 293.

${ }^{2}$ In this thesis, I spell all forms of the verb 'to colonise' with New Zealand English spelling, according to the Oxford New Zealand Dictionary. The only exceptions to this are in quotations where I keep any original spelling.

${ }^{3}$ Throughout this thesis, I will use the term 'indigenous' as the lesser of evils, but I do not wish to imply in doing so that any people described as indigenous necessarily had permanent habitation. It is extremely difficult to describe any population already living on, around, or inhabiting the land that the Greek colonists chose to settle on. All the terminology is problematic. Whitehouse and Wilkins (1989) 115 discuss the issues involved. 'Local' is too imprecise (and I would add that it does not include nomadic peoples); 'indigenous' implies that the peoples have had permanent habitation since the beginning of time; 'native' has modern day colonial overtones (an issue that will be discussed in depth in Chapter One).

${ }^{4}$ The term was coined by Dunbabin (1948), and is a term continuously used to describe the Greeks living in Italy and Sicily (see for example, David Ridgway's (1992) publication The First Western Greeks).
} 
colonies is emphasised by the fact that by the fourth century BC, they may have accounted for some $40 \%$ of all Greeks. ${ }^{5}$

This thesis employs a mixture of literary and archaeological evidence. Much of the textual evidence has a clear grounding in myth, making its historicity questionable. ${ }^{6}$ Some accounts are clearly aetiological ones, created to explain an earlier event or practice. Further, this literary evidence comes from a period (or rather, different periods) considerably after the period of initial colonisation. This factor has implications for our interpretation of the evidence. A second or thirdhand account will never be as accurate as a first-hand one. Later accounts are frequently influenced by popular thought of their time, or shaped to fit contemporary political intentions.

Women do not feature prominently in the textual evidence, but the absence of women from the Greek sources is deceptive. It would be easy to assume that their absence from sources was due to their physical absence during the process of colonisation. Such an argumentum e silentio is unacceptable in this instance: most Greek historical sources in other contexts make very little mention of women. Herodotus provides a great deal of evidence for this thesis because he mentions women more frequently than other writers. He refers to a wide variety of women including wives, daughters, mothers, queens, priestesses, and prostitutes (among others), with a total of 375 mentions throughout the Histories. ${ }^{7}$ By contrast Thucydides, for example, mentions women eight times less frequently than Herodotus. $^{8}$ Like women, indigenous populations are largely ignored in the literary record. Non-Greek sources are virtually non-existent, so we must be mindful of this in our interpretation of the available evidence.

The archaeological evidence also presents challenges. Many excavations were conducted in the nineteenth or early twentieth centuries when the interpretation of the problems of Greek colonisation was very different. As a result, any analysis of the presence of women, indigenous peoples, or skeletal evidence is extremely

\footnotetext{
${ }^{5}$ De Angelis (2011) 18; Scheidel (2003) 134-135.

${ }^{6}$ The distinction between 'myth' and 'reality' was not necessarily recognised by the Greeks. See Dougherty (1993a) 15.

${ }^{7}$ Dewald (1980) 12. Obviously, not all of these mentions concern women in archaic Greek colonies.

${ }^{8}$ Wiedemann (1983) 165.
} 
limited. Ethnicity and identity are big factors in such a project. Typically, we could expect to distinguish between Greeks and various indigenous populations through archaeology - in particular through burial customs and grave goods. However, it is becoming increasingly obvious that this is not straightforward. Many sites reveal a mixture of customs, and also the adoption and adaptation by some groups of the practices of others. ${ }^{9}$ In general, much of the archaeological evidence is open to more than one interpretation and leaves ample room for conjecture and speculation. By the same token, distinguishing male from female in the necropoleis is becoming increasingly more difficult as the common methods of sex association cannot be relied upon (that is, we cannot definitively conclude that graves containing objects typically associated with women also belonged to females). Therefore archaeology provides only limited indications of ethnicity and identity, and must be used with caution. Where possible, the archaeological evidence should be combined with the literary, so that a more rounded picture may be achieved.

What follows is in three parts. Chapter One examines the problems associated with archaic Greek colonisation generally, particularly those issues connected with the 'language of colonisation'. The study of Greek colonisation has been complicated by imprecise and ambiguous terminology, which frequently draws comparison with more modern (although altogether different) instances of the phenomenon. A major repercussion of this is the tendency to overlook both women and any indigenous peoples in the scholarship. Chapter One also examines the various reasons behind the foundation of colonies, possible methods of transport, as well as the different types of settlements, so that an assessment can be made about whether Greek women might have been more likely to accompany colonising expeditions in some instances over others. Chapter Two looks at the concept of intermarriage more closely and assesses the Greek attitude towards foreign women. It also evaluates the evidence typically called upon by scholars to argue for and against intermarriage in Greek colonisation. Chapter Three assesses the evidence of women in ten different colonies. Presented roughly in chronological order, these colonies were selected for their geographical scope,

\footnotetext{
${ }^{9}$ This is partly because, as Owen (2005) 8 points out, ethnicity is a socially-constructed notion, "which may be actively played up or down according to local needs". See also Hall (1997).
} 
covering different regions from the Western Mediterranean, Magna Graecia, North Africa, and the Black Sea. I examine both the literary and archaeological evidence from each colony (where possible), and assess the potential for intermarriage at each place.

Overall, I argue that contrary to the practices of much of the scholarship, archaic Greek colonisation cannot and should not be considered as a uniform phenomenon. Each colony needs to be considered individually, as each colony had a different mother city, a different foundation date, different foundation stories, and accordingly each appears to have had different practices in sourcing its women. Therefore, I argue that based on the available evidence, broad conclusions about intermarriage in the colonies are as risky as broad conclusions about Greek women accompanying men on the colonial voyage. 


\section{Chapter One}

\section{The Prolegomena: Women And Greek Colonisation}

\section{Introduction}

Colonisation is a difficult concept. It is subject to a variety of interpretations, laden with a wide variety of connotations, and applied to a variety of peoples from the ancient Greeks to the Romans and Vikings, from the Spanish, French, and British to the Russians expanding the Soviet Union. In addition, colonisation covers more than people and land: it is also applied to plants, bacteria, and a wide variety of animals. In English today we talk about the colonisation of space, ant colonies, bee colonies, mushroom colonies, and even nudist colonies. Consequently, it is necessary to examine the way in which the terminology associated with colonisation has been used to describe the Greek settlements established in the archaic period, and to identify how this use has impacted on the scholarship.

The language that nineteenth and twentieth century scholars have used to discuss Greek colonisation is often imprecise and sometimes ambiguous. Throughout the twentieth century, there has been a tendency to use terms arbitrarily, with little regard to resulting repercussions. This has led to many of the complications surrounding the study of Greek colonisation.

One of the primary issues in the discussion of colonisation is the association and conflation with contemporary interpretations of the concept. This is particularly evident in western scholarship, where our own experiences of British colonial systems have greatly influenced the way in which we may interpret the colonial experience of others. Many scholars have drawn direct comparisons between Greek colonisation and British colonisation. For example, Australian-born T. J. Dunbabin stated in his preface to the foundational text, The Western Greeks:

I have drawn much on the parallel to the relations between colonies and mother country provided in Australia and New Zealand. Here political independence is combined with almost complete cultural dependence, on which the colonials pride themselves. Difference in 
manner of life is due to difference of material circumstances, and is not enough to destroy the essential unity. This unity is the pride of most colonials; so probably in antiquity. ${ }^{10}$

By comparing ancient with modern colonisation, notions of cultural and political control are insinuated in the colonisation process; in particular, the idea that there are elements of power and domination over any indigenous inhabitants. ${ }^{11}$ For example, in his foreword to Dunbabin's The Greeks and their Eastern Neighbours (1957), John Beazley wrote: "In the West the peoples with whom the Greeks came into contact were at a more primitive stage of development than they themselves". ${ }^{12}$ In 1940, A. H. M. Jones described the Greek colonies in Black Sea as "mere islets of civilization in a sea of barbarism". ${ }^{13}$ These quotations clearly demonstrate the prevailing attitudes of the early twentieth century, deeming the indigenous peoples to be lesser than the Greeks: less advanced, less developed, and perhaps less intelligent as well.

The prejudices against the Aborigines of Australia and the Māori of New Zealand following colonial contact (and arguably continuing to this day) are primarily the result of a colonial view that the colonising group is superior to the colonised, due to perceptions that the latter has a primitive way of life. However, many scholars are beginning to recognise that the Greek outlook on other peoples was, perhaps, very different. The term $\beta \alpha \alpha \rho \beta \alpha \rho o \varsigma$ simply referred to a person who did not speak Greek. ${ }^{14}$ It was not a term tied to any particular people or race, and did not have the same wild and savage connotations that the term carries today. ${ }^{15}$ It appears that the distinction between the Greeks and the barbaroi emerged only following the Persian invasion of Greece in 480/479 BC; many scholars argue that there were no

\footnotetext{
${ }^{10}$ Dunbabin (1948) vii. Dunbabin goes on to analogise the economic life of ancient colonies with modern examples of raw material production.

${ }^{11}$ Osborne (1998) 252.

12 Beazley in Dunbabin (1957) 5. See Ridgway (1990) 62: "'primitive' is not an adjective that I would willingly apply today to the Italian Iron Age".

${ }^{13}$ Jones (1940) 27.

${ }^{14}$ Boardman (1980) 7; Tsetskhladze (2006c) lii.

${ }^{15}$ Isaac (2004) argues against this, though he uses little evidence to back up his assertions, and the purpose of his work, in fact, appears to be to absolve modern society of the creation of racism.
} 
(or few) feelings of contempt or racially motivated hostility prior to this. ${ }^{16}$ It follows that a comparison between Greek colonisation and modern colonisation is not a fair or accurate comparison, particularly because of the very different ways the two approached indigenous populations. The overtones of political and social control associated with modern colonisation were not necessarily present in the settlement process of the ancient Greeks.

More recent scholarship increasingly acknowledges this distinction. Tsetskhladze argues: "colonisation is essentially a modern Anglophone concept, based on examination and interpretation of the imperial activity of the European powers of our era, transported back and forced onto ancient Greece". ${ }^{17}$ Yet, some recent publications continue to link ancient and modern colonisation - not just conflating their interpretation, but also presenting comparative approaches as though they were different versions of the same phenomenon. ${ }^{18}$ This reflects how difficult it is to suppress the instinctual need to relate past events and practices to modern experience, as a way of better understanding those events and practices. But we need to be wary of this, and bear in mind that, other than the term itself, there is little in common between ancient and modern colonisation. In an influential paper, Osborne called for expunging the term 'colonisation' from books on early Greece. ${ }^{19}$ The justification for such a bold appeal was that otherwise "we will go on calling the settlements 'colonies' and will go on mistaking both the causes and the nature of settlement in the West by invoking a colonization model". ${ }^{20}$ While on the one hand, I agree that the conflation of ancient with modern colonisation must cease, I also agree with Whitley's observation, that "we have to call this process something, and colonisation is as good a term as any". ${ }^{21}$ As long as scholars are both aware of the pitfalls of interpretation in previous scholarship, and

\footnotetext{
${ }^{16}$ Tuplin (1999) 54; Antonaccio (2007) 204; Roebuck (1959) 33. Certainly, following the Persian war, previous enemies such as the Trojans gained a retrospective status as "contemptible barbarians" (Tuplin (1999) 55). Hall (1989) argues for the importance of tragedy as a vehicle for inventing and defining 'the barbarian'.

${ }^{17}$ Tsetskhladze (2006c) xxvii. Also recently Snodgrass (2005) 45; Owen (2005); Shepherd (1999) 271. See also Eikeland (2006) 23; Hodos (2006) 10; and in particular, De Angelis (1998) for the critical analysis of Dunbabin's approach.

${ }^{18}$ See Gosden (2004), and Lyons \& Papadopoulos (2002) for examples.

${ }^{19}$ Osborne (1998) 269.

${ }^{20}$ Osborne (1998) 268. De Angelis (2011) 21 argues that we need to coin new terms to use, such as 'apoikiazation' instead of colonisation.

${ }^{21}$ Whitley (2001) 125.
} 
recognise the differences between the ancient and modern processes, then scholarship will continue to move forward.

The ever-changing nature of our understanding of colonisation has almost certainly affected the scholarship on the Greek settlement process in the archaic period. This change is particularly evident in the discussion of the definitions of 'colonisation' in the Oxford Classical Dictionary.

The Second Edition of the Oxford Classical Dictionary, published in 1970, defines Greek colonisation as:

Colonization was always a natural activity for Greeks, living in a poor country. Mycenaean colonies of the Late Bronze Age have been revealed by archaeologists (e.g. at Miletus), the coast of Asia Minor and the islands off it were settled at the beginning of the Iron Age, and there was much colonization in Asia under Alexander and in the Hellenistic period. Nevertheless, the greatest colonizing achievement, by which Greek cities were spread round the coasts of the Mediterranean and Pontus, is that of the archaic period, c. $750-c .550{ }^{22}$

The most recent edition of the same work, published in 2012, saw a drastic change in the definition of Greek colonisation:

'Colonization', in the language of a former imperial power, is a somewhat misleading definition of the process of major Greek expansion that took place between c. 734 and 580 B.C. In fact, the process itself was not so much 'Greek' as directed in different ways and for different reasons by a number of independent city-states. This at least emerges with relative clarity from both the historical and the archaeological evidence. For the rest, the mass of general and particular information that has accumulated under these two headings is only rarely susceptible to a single uncontroversial interpretation. Although the position has greatly improved since the 1930s, it is still only too true that archaeologists and ancient historians do not always appreciate each other's aims and methods - a problem that is

${ }^{22}$ Graham, A. J. 'Colonization, Greek' excerpt from $O C D^{2}$ (1970), 264. 
exacerbated by the fact that on the subject of colonization ancient no less than modern authors are more than usually influenced by their own political agenda and accordingly more than usually liable to project the priorities, practices, and terminology of their own times onto the much earlier events they purport to describe. ${ }^{23}$

This simple comparison shows the radical change in scholarly thinking within just forty years. There is a much greater emphasis placed on terminology; and the problems associated with the subject are more clearly outlined. Importantly, the 2012 edition acknowledges that the settlement process was initiated by different city states, each for different reasons, and most importantly that not all colonies were the same. This is a fundamental point, crucial to avoiding the 'Colonisation Model' which Osborne sought to eradicate. ${ }^{24}$

Modern scholarship often falls into the trap of talking about an 'age of colonisation'. ${ }^{25}$ It is undeniable that migration was a prevalent feature of the ancient world as it remains today. A recurring theme in the Homeric poems concerns men who wander abroad. In Greece, migration took place in the late eleventh to tenth centuries BC, with the Ionians, Dorians, and Aeolians shifting around the Aegean and into Asia Minor, as well as the Mycenaeans' movement prior to this. ${ }^{26}$ Hesiod's father, for example, migrated and chose to settle in Boiotia (Works and Days 630-640). The Hellenistic period was also a period of great migration, into Syria, Egypt, and the East. The movement that took place in the archaic period, however, is frequently singled out as the so-called 'age of colonisation'. Certainly, the colonies of this period stand apart from other periods of migration and settlement partly in their scale and the extent of their geographical reach. Indeed, such was the extent of this colonisation that it remained unsurpassed until the late fourth century BC with Alexander the Great's conquests (which were of a different nature). ${ }^{27}$ However, talking about an 'age of colonisation' is dangerous, as it implies that all the colonies from that age should

\footnotetext{
${ }^{23}$ Ridgeway, D. 'Colonization, Greek' excerpt from $O C D^{4}$ (2012), 348.

${ }^{24}$ Osborne (1998) as discussed above.

${ }^{25}$ For example, Murray (1993) 102, cf. Graham (1982) 83.

${ }^{26}$ Tsetskhladze (2006c) xxiii.

${ }^{27}$ Murray (1993) 102.
} 
be treated as a single movement or phenomenon. ${ }^{28}$ This in turn deceptively suggests that all of the colonies from within that movement were founded for the same reasons, with matching intentions. A careful distinction must also be made between colonisation and migration. Migration occurs when the entire population of a settlement uproots itself (for whatever reason) and relocates to another area to establish a new settlement. By contrast, with colonisation, only a portion of a population relocates while the original settlement (mother city) continues. ${ }^{29}$

The elements required for Greek colonisation are usually discussed within the parameters of some so-called 'long established certainties'. ${ }^{30}$ Some of these certainties are now open to fresh questioning. It is usually assumed, for example, that all colonies were founded by a state (polis) and that consequently, each colony was designed to be a mirror image of its mother city. In fact, colonies could have multiple mother cities as sometimes colonists were collected from all over the Greek world. ${ }^{31}$ In addition, the impetus for the foundation of a colony was not necessarily found in the polis, but could come from a private individual. ${ }^{32}$ Colonising parties are typically described as being led by a single individual, the oikistes. $^{33}$ He was apparently responsible for setting up the social, religious, and political aspects of the new community, and he was usually worshipped as a hero after his death, with his burial in a prominent place in the agora. However, there are instances where there was more than one oikist (such as Metapontum), or

${ }^{28}$ Wilson (2006) 27.

${ }^{29}$ Graham (1981-82) 294 argues that the Greeks did not distinguish between the colonisation that took place in the migratory period and the colonisation of the archaic period. While this may be true, a major theme in this chapter is that nearly all terminology is modern.

${ }^{30}$ See Wilson (2006) 25 for the following list of points of 'long established certainties'.

${ }^{31}$ For example, Cumae appears to have had more than one mother city. See Graham (1964) 16.

32 Consequently, a distinction can be drawn between public and private ventures. For example, Graham (1964) 7-8 (re-emphasised Graham (1982) 143-146) draws a distinction between the foundation of Cyrene as a state act, versus the abortive, and private, expedition of Dorieus (Herodotus 5.42-48). The reasons for these ventures will be discussed later in this chapter. Osborne (1998) shifted the debate significantly, arguing that private ventures alone should account for archaic Greek colonisation in the west. Most recently Morakis (2011) assessed the language used by Thucydides (6.3-5) to argue that the first generation colonists of Sicily were of a private character, while the later expeditions had a more 'state-guided character'. For example, Morakis

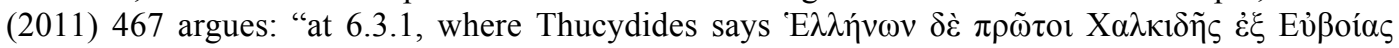

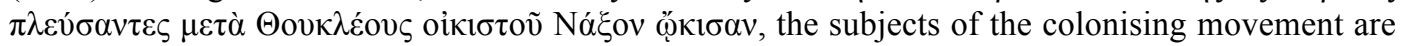
Thoucles the oikist and $\mathrm{X} \alpha \lambda \kappa 1 \delta \tilde{\eta} \varsigma$ but not the state/polis of Chalcis. The ethnic of the colonists (Chalcidians) is used in an indefinite context alongside Thoucles' name and only to denote the geographical origin of the colonists (that is the reason for the $\dot{\varepsilon} \xi$ )." These arguments are heavily tied up with the reasons why colonies were founded, to be discussed shortly, and whether or not the polis was yet in existence. It is also difficult that these debates have a hugely western focus with rare regard to how the situation in the Black Sea may have tallied or differed.

${ }^{33}$ The oikı 
where there is no record of the oikist at all (such as the settlement at Pithekoussai). It is usually assumed that the Delphic oracle was consulted prior to setting out on the colonial expedition to gain approval, advice, or geographical aid. In some instances, such as the foundation of Cyrene from Thera, Delphi was consulted a number of times (Herodotus 4.150-151;155). In other instances, however, Delphi may not have been consulted at all (such as Dorieus' activities in North Africa). ${ }^{34}$ Finally, it is usually assumed that the process of settlement in a new land involved the violent expulsion of the indigenous population. This point is most fundamental to the focus of this thesis and, as we will see, it was not always the case. Some colonies were settled on previously uninhabited land, and conversely, there is strong evidence for others that relations between the Greek colonists and indigenous population were relatively peaceful (such as Megara Hyblaea). Thus, it now appears that little is certain on the list of 'long established certainties'. One of the primary problems with such a list is that, as we will see, it fails to acknowledge that every single Greek colony differed from the next, even those which had the same mother city. Such 'long established certainties' fit within the 'age of colonisation' argument, and consequently they do not seem to often coincide with the reality of Greek colonisation. Furthermore, Malkin points out that many of the expectations or conditions associated with the foundation of Greek colonies are in fact ones that date to the classical period, and therefore are not applicable to those of the archaic period. ${ }^{35}$

\section{Practical considerations}

As an alternative to this 'one size fits all' approach, it is useful to consider in practical terms what was required to make a colonial expedition work. In the first few years of existence, the new settlements would have needed to have been relatively self-sufficient. Food, water, and shelter were all essential to survival. With a view towards more long-term survival, certainly an ability to reproduce was crucial and this obviously required women.

Homer's Odyssey (9.116-24) gives us some indication of what colonists looked for in an area to be potentially settled:

\footnotetext{
${ }^{34}$ Interestingly, at least in this instance, the foundation's inability to succeed has been directly linked to their neglect to consult Delphi - see Herodotus (5.42).

${ }^{35}$ Malkin (1987) 155.
} 


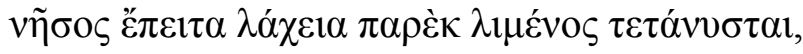

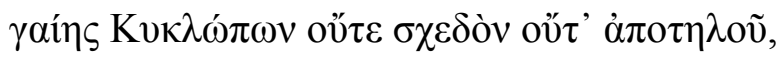

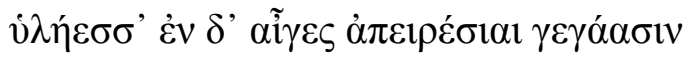

ä $\gamma p 1 \alpha 1 . .$.

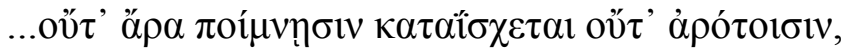

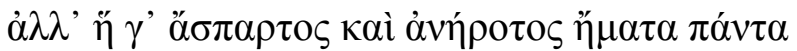

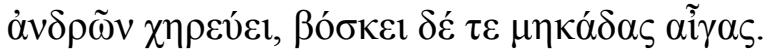

There is a fertile, wooded island stretching before the harbour, neither near the land of the Cyclopes, nor far away, in which countless goats live wild...used neither for flocks, nor corn-fields [ploughing], but in fact is unsown and unploughed for all the days, it lacks men feeding only bleating goats. ${ }^{36}$

The island is currently uninhabited and is fertile. Though technically Odysseus is not looking to found a colony, he is aware of its potential for settlement and consequently this passage is commonly seen to reflect the ideals of colonisation. ${ }^{37}$

The number of colonists required for each expedition is not known, but presumably this could vary considerably. Herodotus (4.153) records that two pentekonters voyaged from Thera to Cyrene; many scholars have presumed, incorrectly, that this meant 200 people went to the new colony. ${ }^{38}$ Morrison and Williams' study, Greek Oared Ships demonstrates that a pentekonter typically carried 50 oarsmen and two officers. ${ }^{39}$ By contrast, Herodotus, elsewhere, allows for 80 men in each pentekonter (7.184.3). ${ }^{40}$

The debate surrounding which kinds of vessels were used on colonial voyages becomes particularly salient for the Black Sea colonies; specifically the date that the Greeks were able to sail into the Black Sea, and therefore the earliest possible date of settlement. There are references to the region in mythological traditions (for example, the Argonauts' voyage to Colchis in search of the golden fleece), though scholars have struggled to place these instances chronologically. ${ }^{41}$ In 1948

\footnotetext{
${ }^{36}$ All translations and bolded emphasis are my own.

${ }^{37}$ Wilson (2006) 39.

${ }^{38}$ See for example, Dunbabin (1948) 454; Murray (1993) 113; Graham (1964) 43. Furthermore, I thank Arthur Pomeroy for pointing out that these two pentekonters could have been for military support, and not the vessels containing the colonists.

${ }^{39}$ Morrison \& Williams (1968) 47. See also Van Wees (2004) 203.

${ }^{40}$ See Cawkwell (1992) 290 for other possibilities, such as the addition of a sigma after öv $\delta \rho \alpha \varsigma$ to show that it was 200 men.

${ }^{41}$ Tsetskhladze (1994) 114; Petropoulos (2005) 17.
} 
Carpenter became the leading proponent in this debate, publishing an article which concluded that the Black Sea was closed to the Greeks before c. 680 BC, due to the strong Bosporus current. ${ }^{42}$ Carpenter argued that access to the Black Sea was tied to the invention of the pentekonter, thus explaining why there is little archaeological evidence before this time. ${ }^{43}$ It was necessary for crews to row pentekonters through the entrance to the Black Sea, as sailing through was not possible. In 1957 Labaree conducted a more technical analysis of the capabilities of the pentekonter, ${ }^{44}$ and a similar study was undertaken by Graham in 1958 to assess the effects of the wind and currents on access to the Black Sea, whether by sailing or rowing. ${ }^{45}$ Both concluded that the Greeks were in fact able to sail into the Black Sea, and thus the date of the Greek penetration of the Black Sea did not rely on technical improvements in rowing vessels. ${ }^{46}$ Graham reasserted his opinion in 1971, and added that the absence of Greek colonies (particularly with reference to the northern shores of the Black Sea) was due to the 'warlike strength' of the indigenous population. ${ }^{47}$ Graham re-emphasised his position in 1990, attempting to use some pottery as evidence. ${ }^{48}$ The limitations of this approach were criticised by Boardman in 1991:

whether there is any archaeological evidence for earlier exploration or settlement is another matter, but Graham has pressed claims which, as I hope to show, cannot be upheld since the dating of the pottery or its

\footnotetext{
${ }^{42}$ Carpenter (1948).

${ }^{43}$ Carpenter (1948). Carpenter chooses his access date, citing Thucydides (1.13), who states that there were improved ship building techniques at Corinth during the same period. Carpenter misinterprets Thucydides, who also states that the Corinthians were the first of the Greeks to have triremes (not pentekonters), and that Ameinocles made four of these ships for the Samians (and so is typically seen as being the first Greek to build triremes - see Graham (1958) 26-27). Furthermore, little extensive archaeological exploration had been conducted at Carpenter's time of writing.

${ }^{44}$ Labaree (1957) 31.

45 Graham (1958) 29-30.

${ }^{46}$ It would be highly unlikely that a group of colonists would depart their mother city to settle in new lands without sufficient provisions to last them past the initial settlement period (however long that may have been). As such, the pentekonter, with its limited storage space, seems less likely to have been used. Hence, the ships that were used by the colonists would, in all probability, have been able to access the Black Sea by sailing into it.

${ }^{47}$ Graham (1971) 39. This is of course extremely contentious. It is not yet clear whether the territory surrounding the Black Sea was heavily populated or not; an issue complicated by the nomadic character of the indigenous peoples. See Tsetskhladze (1998b) 44. (This is an issue that will be discussed in the Black Sea section of Chapter Three). Drews (1976) supported this argument a few years later.

${ }^{48}$ Graham (1990) 53-54.
} 
pedigree are either wrong or too dubious to be taken seriously, however tempting they may seem. ${ }^{49}$

There have been few significant developments in this debate since. Tsetskhladze readdressed the arguments in 1994, but did not produce any new conclusions. However, arguably more importantly, he did outline the reasons behind the longrunning controversy: most fundamentally, acknowledging the dearth of any substantial archaeological evidence on which to base an opinion, coupled with a lack of any strict chronology to support an assessment. ${ }^{50}$

From this examination of vessels, it seems that pentekonters were an unlikely means for transporting Greek women to colonies. They were designed specifically as vessels that were not necessarily dependent on winds but could be manipulated by the sheer force of rowers. ${ }^{51}$ As such, their design departed drastically from the old, sailing merchant ships. Instead of having a broad, deep hull to allow for maximum storage space, the pentekonter was long and narrow, with a shallow draught to allow for high-speed propulsion. ${ }^{52}$ Consequently, there was little room for storage as the available space was taken up by the multiple rowers required to propel the ship. This, however, does not seem to correspond to many textual references to pentekonters. For example, Herodotus (1.163.1-2) states that the Phocaeans were the first Greeks to make long sea voyages and he specifically

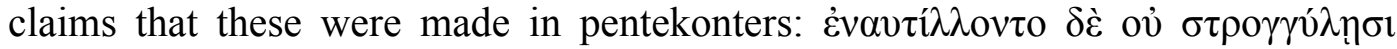

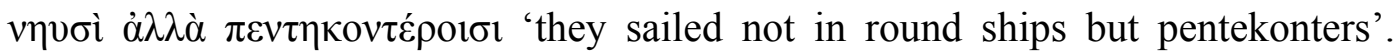
This is difficult to reconcile with the fact that the Phocaeans were sailing to locations famous as trading ports, such as Tartessus, and they would presumably therefore require space in their vessels to transport both goods to sell and goods purchased. $^{53}$ In another instance, Herodotus (1.164) describes how during the

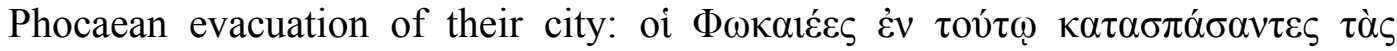

\footnotetext{
${ }^{49}$ Boardman (1991) 387.

${ }^{50}$ Tsetskhladze (1994) 111-112.

${ }^{51}$ See Labaree (1957) 31 for a cogent description of the pentekonter. There is frequent conflation of the pentekonter and the trireme in the aforementioned arguments - see Van Wees (2004) 202206 for clarification. At this time, such ships were typically owned by private individuals; there was no state-owned war fleet such as that possessed by Athens in the fifth century BC. This point could potentially impact on the debate surrounding whether colonial voyages were public or private ventures.

${ }^{52}$ Koromila (1991) 24

${ }^{53}$ Graham (1990) 45.
} 


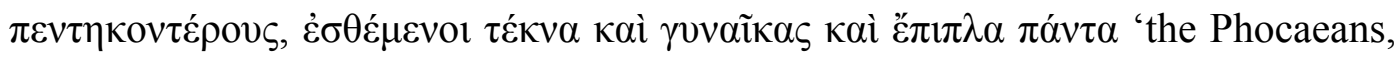
in the meantime, pulled down the pentekonters, and put in the children, and women, and all moveable property'. For colonial voyages, it must be assumed that, at the minimum, some crops were transported for planting in the new settlement. ${ }^{54}$ In the Black Sea, for example, Pashkevich's study demonstrates that the Greek colonists did not plant crops that were indigenous to the Black Sea, but instead brought crops with them from the Greek mainland. In the case of Cyrene, too, Herodotus (4.151-152) reports that the Theraean colonists left Corobius, their guide, on an island (Platea) with enough supplies for a number of months, which would seem to be far more than a pentekonter could have carried. ${ }^{55}$

This is clearly not a straightforward issue, nor one that offers an easy answer. It seems that the textual references refer to a different type of 'pentekonter' from our understanding of it as a long, shallow vessel with 50 rowers. Visual representations are also of little help given the stylised images characteristic of the Geometric style. ${ }^{56}$ For colonial voyages with even a modicum of planning prior to departure, some storage space to transport goods would have been imperative. If women were to be sent out to the colony at a later date, possibly with another wave of second-generation colonists, some holding space in their transport vessel would have been necessary. It is inconceivable that women could have rowed the ships themselves. Consequently, we must conclude that the ships used for colonial voyages, typically called pentekonters in the literary evidence, had some provision for storage space, and were therefore not pentekonters of the type known from later sources.

\section{Reasons for founding colonies}

The reasons behind overseas Greek settlement in the archaic period have been a much loved topic for debate. The approach to this debate, however, usually assumes that there could be only one reason why all of the colonies were founded. In reality though, it appears that each colony differed from the next. Some

\footnotetext{
${ }^{54}$ Pashkevich (2001).

${ }^{55}$ See Petropoulos (2005) 124.

${ }^{56}$ Morrison \& Williams (1968) 39 point out that, due to issues of perspective, it is difficult to distinguish between a ship with two levels of rowers, and a ship where both sides of the ship are depicted. See also Kirk (1949); Popham (1987); Pomey (1996).
} 
possible reasons for the overseas expansion will be outlined below, and these will be further synthesised in the case studies in Chapter Three.

For a long time, historians championed overpopulation as the primary reason for the foundation of Greek colonies. ${ }^{57}$ This may have stemmed from the influence of later Greeks, such as Plato, who wrote that founding colonies was a cure for overpopulation (Laws 740e), and compared it to the way a swarm of bees settles a new hive (Laws 708b). Certainly, logically, overpopulation would provide good reason to create new settlements. However, although difficult to document, there is little evidence that overpopulation was ever an issue. ${ }^{58}$ Camp concluded that the closing of many of the wells in the Athenian agora in the late eighth century BC, coupled with the increase in graves at the time, were signs of the conditions that could lead to colonisation - drought and overpopulation. ${ }^{59}$ Such regional arguments are highly problematic however. Camp's hypothesis is based on a small area of Attica, ${ }^{60}$ and moreover, Attica (and the Argolid) is well-recognised as being one of the only areas not to send out any colonies. ${ }^{61}$ Furthermore, several regions of mainland Greece remained uninhabited well into the archaic period, and therefore overseas expansion was not necessarily required to solve overpopulation. These factors are incongruent with Camp's conclusions. By the same token, those areas which were prolific colonisers, such as Euboea, Corinthia, or the Megarid, yield no hard evidence that their population was rising. ${ }^{62}$ Therefore it seems unlikely that strict overpopulation by itself was a primary cause for colonisation. ${ }^{63}$

As a variant of this concept, Van Compernolle suggests that overpopulation was caused by uneven land distribution and that the colonising party was made up of people who had no access to resources for survival in their homelands. ${ }^{64}$ Such

\footnotetext{
57 See for example Gwynn (1918); Littman (1974); Snodgrass (1980); Van Compernolle (1983); Waters (1974); Owen (2005).

${ }^{58}$ Scheidel (2003) 121; 131 argues that it is unlikely that historical populations ever reached full saturation level.

${ }^{59}$ Camp (1979).

${ }^{60}$ Holloway (1981) 144. Holloway also points out that other factors could have caused this phenomenon such as a local instability of ground water in the agora.

${ }^{61}$ Whitley (2001) 125-126.

62 Tsetskhladze (2006c) xxviii.

${ }^{63}$ Overpopulation has also been proffered as a reason for the foundation of secondary colonies, such as Selinus, a secondary colony of Megara Hyblaea. De Angelis (1994) presents a very compelling study showing that Megara Hyblaea was using only a fraction of its available land so it is unlikely that Selinus was founded due to overpopulation.

${ }^{64}$ Van Compernolle (1983) 1037-1038.
} 
regional problems may have been exacerbated by some sort of natural or climatic disaster and this has also been linked to the overpopulation argument. ${ }^{65}$ Certainly, Herodotus (4.151) reports that the Theraeans were suffering from an extensive drought, which eventually compelled them to seek advice from Delphi, who in turn advised them to found a colony in Libya (and indeed, this is presumably the genesis of the overpopulation argument).

The reasons outlined above each affected the entire mother city population. Accordingly, if a colony was the product of overpopulation or some sort of natural disaster, it would seem likely that a wider cross section of the community would leave to settle in new lands. Consequently, there was potential for women to accompany men on these voyages.

Other factors driving overseas settlement made the participation of women less likely. One of these, the simple desire to acquire more land, could have been a strong motivating factor for landless men to found new colonies. Thucydides

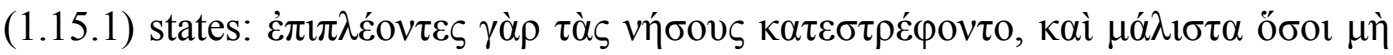

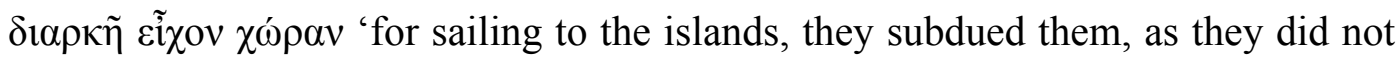
have sufficient land of their own'. Crielaard adds that part of the attraction of colonisation could have been simply that 'conquering' territory appealed to the aristocratic warrior ethos. ${ }^{66}$ The desire for new land was also intimately tied up with trade and wealth. Indeed, Blakeway famously questioned whether 'the flag followed trade'. ${ }^{67}$ Certainly this could explain why many Greek colonies (for example, Pithekoussai, Massalia, Heraclea Pontica, to name a few) tended to be settled on the fringes of the Greek world, rather than close to contemporary settlement; trade vessels were potentially more likely to stop at the terminus of a trade route than halfway en route ${ }^{68}$ Knowledge of fertile land or the existence of

\footnotetext{
${ }^{65}$ Cawkwell (1992) 301.

${ }^{66}$ Crielaard (1992-93) 242. See also Dougherty (2001) 137; Dougherty (1993b) for the violence associated with colonisation.

${ }^{67}$ Blakeway (1932-1933) 202. Osborne (1998) 268-269 sees this as an inappropriate discussion as talk of a 'flag' is anachronistic. While this is certainly true, the argument in its essence still holds true: did trade come before settlement?

${ }^{68}$ Cawkwell (1992) 296. For example, the hugely successful trading port Tartessus was located on the south coast of the Iberian peninsula through the 'Pillars of Herakles' (see Herodotus 4.152).
} 
raw resources may have also been a motivating factor for setting out colonies. ${ }^{69}$ Simple desire to gain more agricultural land appears as a trait of the later colonies, and so 'land hunger', as it were, may well have been fuelled by the knowledge and experience gained by the early Greek colonies overseas. ${ }^{70}$

Civil strife at home presents another potential reason why Greeks founded colonies. Factional disputes could lead to certain individuals or groups being ordered (or choosing) to leave the mother city. Crielaard connects this factor, in particular, with the aristocracy - the socio-political and religious functions were largely carried out by the elite, and the impact on these of the changes associated with the development of the polis could have motivated many aristocrats to seek alternative settlements, in the form of new colonies overseas. ${ }^{71}$ Such ventures could well have fallen into the 'private' ventures category, rather than the 'public'. The colony Locri Epizephyrii appears to have been an example of this.

Although previously, scholars promoted overpopulation as the sole reason behind the foundation of archaic Greek colonies, there is little evidence to support such a theory. Instead, colonies seem to have been founded for a variety of different reasons. Accordingly, each colony had the potential to differ from the next.

\section{Different types of settlements}

During the archaic period, Greek settlements are typically described as falling into two categories: the apoikia and the emporion. This distinction has previously been of central focus in the scholarship. ${ }^{72}$ I will examine each in turn to determine whether the settlement type had any bearing on the presence of women.

The first type of Greek settlement is the apoikia. The Greek lends itself to a definition; literally meaning 'a home away from home' ${ }^{73}$ an apoikia is a settlement

\footnotetext{
69 For example, evidence of Mycenaean contacts with Magna Graecia can be seen in the archaeological record, and Antonaccio (2005) 97 argues that contacts between Italy and Greece probably remained uninterrupted. Consequently, knowledge of the attractiveness of Magna Graecia (at least) was likely to have been reasonably widespread.

${ }^{70}$ Whitley (2001) 126.

${ }^{71}$ Crielaard (1992-93) 240-241.

72 See, for example, Whitley (2001); Hansen \& Nielsen (2004); Wilson (2006); Wilson (1997); Hansen (1997); Demetriou (2011).

${ }^{73} L S J$ sv. åmoikía.
} 
that is theoretically designed as a mirror image of its mother city. ${ }^{74}$ The settlement was set up in such a way that it could fulfil a popular ideal of the time, autarkeia, or self-sufficiency. ${ }^{75}$ Presumably then, agriculture was an essential part of these communities in order to produce food to ensure survival in a self-sufficient way. However, as discussed above with the 'long established certainties', the ideals attached to these new settlements did not always line up in reality.

Scholars have claimed that an apoikia was itself a polis, which reflected the polis from which it originated. ${ }^{76}$ This, however, is problematic. In the eighth and early seventh centuries $\mathrm{BC}$, when many overseas colonies were established, the ideology of the polis was not yet fully developed, and consequently, as Wilson puts it, was "certainly incapable of spawning a child of its own". ${ }^{77}$ Some arguments, such as that canvassed above, that an apoikia was a settlement striving to achieve autarkeia, do not hold up: autarkeia as a concept came into play much later, during the fourth century $\mathrm{BC}$, as a response to the increasing dependence of the polis on foreign trade. ${ }^{78}$ Following this line of reasoning, some scholars have argued that the so-called 'age of colonisation' was an essential part of the development of the polis, as colonies became more independent from their mother cities. $^{79}$ Thus, it is hard to support the idea that the polis was necessary in order for colonisation to succeed. Malkin aptly states:

the act of sending away entire groups to colonize abroad was not necessarily evidence of a well-organized, coherently formed political community (polis) at home. Sometimes, it was the very act of

\footnotetext{
${ }^{74}$ Hodos (2006) 19. This is course is an ideal, and as we will see in Chapter Three, the reality was often quite different.

${ }^{75}$ Wilson (1997) 205.

${ }^{76}$ Wilson (1997) 199; Hodos (2006) 19.

${ }^{77}$ Wilson (1997) 199. See also Van Compernolle (1983) 1037; Malkin (1994b) 1; Ridgway (1992) 108. The debate surrounding the formation of the polis is vast and ongoing. With regard to Greek colonies, poleis are typically thought to have had fortification walls; however, at the early period of development of the polis concurrent with the foundation of colonies, there were no city walls. Karlsson (1989) traces the first defensive walls in Sicily to the period of tyranny. See also FischerHansen (1996) 319. By contrast, de Polignac (2005) 47 argues that some primitive enclosures separated the interior urbanised area from the 'outside' in the archaic period, primarily following so-called 'accidents of topography' (that is, naturally occurring phenomena such as ridges, watercourses, or the edge of a plateau).

${ }^{78}$ Wilson (1997) 205.

79 Murray (1993) 102-3; Hodos (2006) 19-20; Wilson (1997) 205; Ridgway (1992) 107 also suggests that Pithekoussai, in particular, encouraged the polis to the shape for which it was later known. Holloway (1981) 147: "urbanism and the emergence of the polis also seem to accompany rather than to precede the stimulus of colonization".
} 
separation and colonization which formed, homogenized, and consolidated the "mother city" as polis. ${ }^{80}$

Another important distinction to note contrasts the Greek apoikia with the Latin colonia. Various scholars have demonstrated that the two terms have become virtually synonymous in modern scholarship. ${ }^{81}$ However, they are in fact very different. The Latin term incorporates a reference to agriculture. ${ }^{82}$ Roman colonisation also had a distinctly imperial character. Consequently, when the two terms are paired, Greek colonisation, too, is given an imperial character which, in reality, it never had. ${ }^{83}$ While colonia was in fact a technical term used by the Romans, the Greek 'equivalent', apoikia, cannot be seen as an official term employed by the Greeks. Rather, it was a generic description used for a variety of settlements. ${ }^{84}$ The conflation of the two terms has been traced back to the fifteenth century $\mathrm{AD}$, when Lorenzo Valla translated Thucydides' Greek apoikia as the Latin colonia. ${ }^{85}$ Obviously, the English term, 'colony' directly stems from colonia, and consequently, those same notions of imperialism were transferred. Thus, it is easy to see the confusion when English terms are used to describe the Greek process. Hansen and Nielsen argue that 'emigrant community' would be a better translation for apoikia than colony. ${ }^{86}$

A second type of settlement is the emporion. Traditionally, emporia are thought to have had a distinctly economic function, primarily relying on the import and export of goods for a reason for existence and continued survival. ${ }^{87}$ The characteristics of an emporion can be found in Herodotus' (2.178-180) description of the Egyptian settlement, Naucratis. These features included a harbour, a quay,

\footnotetext{
${ }^{80}$ Malkin (1994b) 2.

${ }^{81}$ Osborne (1998) 252; De Angelis (1998) 539; Finley (1976) 173.

${ }^{82}$ Colonia, -ae derives from colonus $-i$, the tiller farmer, and is also linked to the verb, colo, colere, meaning to till, cultivate, or inhabit (OLD sv. colonia). Gosden (2004) 1-2 has drawn attention to how in modern times, the 'terra nullius' law denied the indigenous population rights to their own land because they did not till it. The concept of this law is bound up with the Latin term, colonia.

${ }^{83}$ Hodos (2006) 19.

${ }^{84}$ Wilson (2006) 28.

${ }^{85}$ De Angelis (1998) 529; Hodos (2006) 19.

${ }^{86}$ Hansen \& Nielsen (2004) 150.

${ }^{87}$ Hodos (2006) 19. This is largely because the Greek emporion has been assimilated with Karl Polanyi's (1963) famous 'port of trade' concept, which was intended to be a universal institution. However, as Figueira's (1984) publication argued, the port of trade was a heuristic concept that did not translate through to the Greek word, emporion. See Polanyi (1963); Demetriou (2011) 256.
} 
warehouses, administrative buildings, and a food market. ${ }^{88}$ Because an emporion did not necessarily have a permanent population, but instead had traders coming and going, it is perhaps less likely that Greek wives would have lived within the settlement, or that much intermarriage occurred. Alternatively, hetairai are noted as being present. ${ }^{89}$ For example, at Naucratis, a settlement which was famed for its hetairai according to Herodotus (2.135.5), Rhodopis is mentioned in a number of sources as the most well known hetaira. ${ }^{90}$ In a settlement that was seemingly designed around trade, where better for hetairai to pursue their own business.

Like the apoikia, the emporion has also become assimilated with the concept of the polis. Settlements which have been argued to be emporia are, more often than not, also described as poleis (sometimes in addition to an emporion) by ancient sources. Herodotus makes nine references to emporia. ${ }^{91}$ One of these is the Milesian colony, Olbia, in the Black Sea. ${ }^{92}$ The physical location of this settlement on the mouth of the River Bug would have placed it ideally for trade with the neighbouring Scythians, and this was arguably its initial purpose. However, by the sixth and early fifth centuries BC, the town was minting its own (unusual, dolphinshaped) coinage, and had an elaborate town grid plan laid out, neither of which is a trait of a community solely constructed for commerce. ${ }^{93}$ Looking at the written evidence, Herodotus (4.17.1) states that Olbia is the emporion of Borysthenes. ${ }^{94}$ However, slightly later, Herodotus (4.18.1) recognises that the inhabitants of Olbia called themselves 'O $\lambda \beta 10 \pi \circ \lambda i \tau \alpha \varsigma$, which therefore implies that the people of Olbia believed their city to be a polis in its own right. Clearly Herodotus' use of the terms emporion and polis demonstrates that the two are not mutually exclusive. Instead, Wilson suggests that when Herodotus describes a polis as being an emporion, he is merely stressing the significance of trade to that city. ${ }^{95}$

\footnotetext{
${ }^{88}$ Hodos (2006) 19.

${ }^{89}$ Moller (2001) 152.

${ }^{90}$ Rhodopis is mentioned by Herodotus (2.134-5); Strabo (17.1.33); Athenaeus (13.596c); Sappho (fr. 202).

${ }^{91}$ Wilson (1997) 204.

${ }^{92}$ This settlement will be further examined in Chapter Three.

${ }^{93}$ Wilson (1997) 204.

${ }^{94}$ Hind (1997) 109.

${ }^{95}$ Wilson (1997) 204.
} 
This would certainly appear to be the case for settlements such as Naucratis, a settlement which is largely agreed to be an emporion, ${ }^{96}$ which lacked both a mother city and a permanent Greek settlement, and which instead focused its efforts on trade. Accordingly, it would be easy to assume that Naucratis was definitely not an apoikia, and was solely an emporion. For example, Herodotus (2.179) calls Naucratis an emporion. However, Naucratis is called a polis in the first line of a fourth century $\mathrm{BC}$ honorary decree $(O G I S$ 120): $\dot{\eta} \pi$ ó $\lambda 1 \varsigma \dot{\eta}$

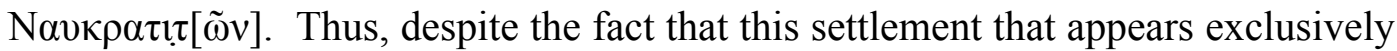
to fit the definition of an emporion, ancient sources (though admittedly much later than the period directly being dealt with here) do not follow suit so closely. Again, we are left to conclude that the emporion and the polis are not mutually exclusive terms and that their meanings overlap.

It is crucial to note that the word emporion itself does not in fact occur in any extant archaic text. ${ }^{97}$ Herodotus, though one of the earliest sources available to modern historians, was writing in the fifth century BC. The oldest extant inscriptions in which the word 'emporion' occurs also date from the mid-fifth century BC. For example, two boundary stones found in the Piraeus at Athens are

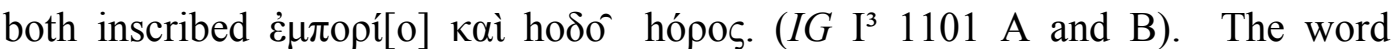
emporion is also found in a fragmentary decree presumably regulating the foundation of a colony: $\tau 01 \varsigma \varepsilon \mu \pi \mathrm{o} \rho[\mathrm{or} \varsigma]\left(I G \mathrm{I}^{3} 47 \mathrm{~A} .7\right){ }^{98}$ Apart from this evidence from the fifth century $\mathrm{BC}$, we have no extant material to indicate that the Greeks had developed the concept of an emporion prior to this.

The one exception to this is the name of the archaic colony called 'Emporion' (Spanish: Ampurias) in Spain. ${ }^{99}$ Founded in c. 550 BC, the name of the settlement, Emporion, seems to be the earliest reference to the term (here used as a proper noun), roughly a century before it appears in Herodotus. Thus, we are left with a 'chicken and egg' conundrum; did the term come from the colony, or was the

\footnotetext{
${ }^{96}$ As opposed to settlements such as Pithekoussai where there is continued debate as to its emporion status. See especially Ridgway (1973) 107-120; also Wilson (2006) 34; Graham (1982) 103; D’Agostino (1996) 535-536; Mertens \& Greco (1996) 243.

97 Hansen (1997) 84. This article was reprinted in Tsetskhladze (2006a), with the primary difference being that in the latter publication, Hansen explicated his belief that emporia did exist in the archaic period, making his argument much clearer.

${ }_{98}^{98}$ These epigraphical examples were suggested by Hansen (1997) 84.

${ }^{99}$ Hansen (1997) 94.
} 
colony named after the term? Demetriou's analysis of the cadastral studies of Emporion helps answer some of these questions. ${ }^{100}$ Originally, as has been discussed above, scholars assumed that emporia would have had much smaller areas of territory than apoikia, relying on trade rather than agriculture for survival. Certainly at Emporion, it appeared that the settlement itself was small (roughly four hectares) and had a quite limited territory. ${ }^{101}$ However, the cadastral studies present a different story. Roads ran outwards from the settlement to the country. Furthermore, much of the surrounding country was divided up into kleroi (parcels of land), which according to Demetriou were marked out following the same measurements used in the mid-sixth century BC in mainland Greece. ${ }^{102}$ Given the corresponding measurements, the kleroi at Emporion may have existed since the founding of the settlement. ${ }^{103}$ It is not so clear however, whether the indigenous population were included in the distribution, nor how long the kleroi were maintained. ${ }^{104}$

Hodos claims that the Greeks were not consistent in their use of the terms apoikia and emporion. ${ }^{105}$ This appears to have been because the Greeks did not make significant distinctions between the various population movements. ${ }^{106}$ This in turn suggests that the Greeks did not give the same importance to exact definitions and applications of the two terms. If that is so, the confusion in the ancient language is in fact more recent, and is heavily tied in to the confusion in the modern definitions as well. Tsetskhladze sensibly remarks: "terminology can never reflect the full reality - it can illuminate or distort in equal measure". ${ }^{107}$ For this reason, the distinction between an apoikia and an emporion does little to illuminate the position of women.

\footnotetext{
${ }^{100}$ Demetriou (2011) 263-264.

${ }^{101}$ Demetriou (2011) 264.

102 Demetriou (2011) 264.

${ }^{103}$ We could perhaps assume from this that each of the colonists started on an even par at the beginning of the settlement. Because we know so little about how Greek colonists were selected for colonial voyages, we know little about the status of colonists. Further exploration in this area, using such cadastral studies, could be a good place to make headway in this debate.

${ }^{104}$ For example, contrast to the Spartan land tenure system, where we are equally uncertain about how long the kleros system remained unchanged following the land reforms of Lycurgus. We know that they must have changed at some stage, as some Spartans were in possession of more than one kleros, even if they maintained their original proportions. As with the Spartan system, such a land tenure system does not necessarily provide that everyone will receive land of similar quality, even if the quantities were roughly equal.

${ }^{105}$ Hodos (2006) 19.

${ }^{106}$ Wilson (2006) 29.

${ }^{107}$ Tsetskhladze (2006c) xxviii.
} 


\section{Conclusion}

The foregoing demonstrates that colonisation remains a difficult concept to define. This is partly because it is not entirely clear what the Greek colonisation process involved, but also largely because the term has become entwined with other meanings over a long period of use. It has become a multifaceted term which can be attached to a number of different processes. Greek colonisation has become conflated with our modern concepts of colonisation, especially that undertaken by the British. This has given Greek colonisation an imperialist flavour, and coloured views about the way women and any indigenous population are considered. As a result, the study of Greek colonisation has undergone many changes in emphasis and interpretation throughout the twentieth century.

Though we are not entirely clear what the Greek colonisation process involved, we can be certain that food, water, and shelter would have been necessary to ensure survival. Similarly, an ability to reproduce would have been crucial to the continuation of any colony. There is significant uncertainty about the type of transport used to reach the new settlements. The textual evidence, in addition to the various studies completed on the Black Sea, and arguments from logic, strongly suggest that pentekonters were used to transport colonists. However, this does not correspond with our understanding of the pentekonter as a long, shallow vessel with no storage space. Until this issue is resolved, we can only speculate about whether (or perhaps, how) ships may have transported women and basic possessions to the colonies.

There also appear to be many diverse reasons for founding colonies. No one reason can be adduced from the evidence as dominant, and in all likelihood, each colony had a different founding impetus from the next one. Thus, some explanations are consistent with the presence of women in colonial voyages, whereas others indicate that women would more likely be found from within indigenous populations. Similarly, the different types of settlement - apoikia versus the emporion - could determine whether women were involved and how their involvement played out. In reality, however, it appears that the distinction commonly drawn between these different settlement types is one that did not necessarily exist in the ancient world. Accordingly, the different settlement types 
may not have been a strong determinant of the presence of women, and in that case, an assessment of settlement types does little to further the issue of whether Greek colonists brought Greek women or intermarried with the indigenous population. 


\section{Chapter Two}

\section{Intermarriage: A Normal Practice?}

This chapter introduces the concept of intermarriage and assesses whether the Greeks considered intermarriage a normal practice, both in the context of colonisation and outside. The evidence typically put forward to argue both for and against intermarriage in the archaic Greek colonies will then be considered.

\section{'Intermarriage' as a concept}

For the purposes of this thesis, I am choosing to view foundation scenarios in relatively black and white terms to simplify an already very complex issue. Specifically, I will consider whether male Greek colonists brought their own wives with them (or by extension other Greek females), or whether male Greek colonists intermarried with indigenous females. ${ }^{108}$ Crucially, I am assuming that the majority of Greek colonists would have always been male, and therefore, that intermarriage only took place between Greek males and indigenous females, rather than the other way around. My focus is largely on first generation colonists. 'Intermarriage' encompasses both consensual and non-consensual relationships, or rather, marriages produced and recognised in peaceful circumstances as well as those that were a product of force. It is also important to acknowledge that the nature of such marriages could be considerably more casual than our modern definition of marriage.

A study of the relationships between the Greek colonists and the various indigenous peoples is essential to this discussion. This is not always straightforward. Graham aptly states:

of the many deficiencies in our evidence for Greek colonization in the archaic period, one of the worst is the lack of good information about the native peoples among whom the Greeks established their new settlements. ${ }^{109}$

\footnotetext{
${ }^{108}$ Of course, a mixture of these options could have occurred - some Greek wives accompanied their husbands, while other men intermarried. They are not mutually exclusive, though they do tend to be presented in the scholarship as such.

${ }^{109}$ Graham (1988) 304.
} 
Nevertheless, it is useful to consider whether relations between the Greeks and the indigenous populations were hostile or friendly, particularly on the arrival of the colonists, to indicate whether intermarriage could have been an option. Of course, as Shepherd points out: "good and bad relations with the indigenous population do not necessarily facilitate or preclude intermarriage". ${ }^{110}$

It is also important to consider whether the Greeks themselves perceived intermarriage as being a normal practice. As was briefly discussed in Chapter One, many scholars argue that the Greeks did not attach any great stigma to the barbaroi, or see them through a racist lens. ${ }^{111}$ Consequently, it is unlikely that Greek men would have felt any reluctance towards taking a non-Greek wife. ${ }^{112}$ Further, Greek traditions long recognised that wars were often started over women, and that women were frequently part of the plunder. ${ }^{113}$ As Rihll argues: "the Greeks considered taking, by force if necessary, to be a normal and legitmate method of acquisition". ${ }^{114}$ Taking women by force was simply an extension of this behaviour. This attitude is made clear in Homer's Odyssey (9.39-42).

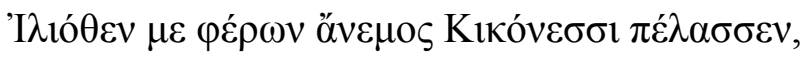

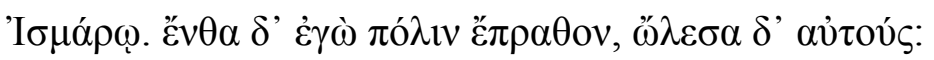

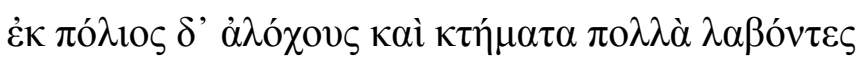

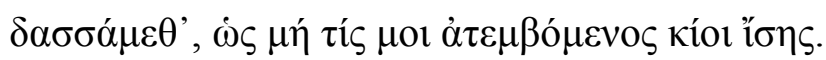
From Troy the wind carried me and brought me to Ismarus of the Cicones. There I sacked the city and I destroyed the men. Having taken the wives and many possessions from the city, we divided them so that no one was cheated of an equal share.

Other ancient peoples shared this attitude. For example Dionysius of Halicarnassus (Antiquitates Romanae 2.30.5) states that when Romulus and his companions seized and married the Sabine virgins (usually referred to as the 'Rape

\footnotetext{
${ }^{110}$ Shepherd (1999) 292.

${ }^{111}$ See above footnote 16 .

112 Rouge (1970) 307. See Just's (1989) 40-75 chapter on 'Marriage and the State' for the distinctions between different types of women. We must be mindful however, that many of the terminological distinctions only became prevalent in the classical period.

${ }^{113}$ Herodotus provides evidence for this view, explaining much of his Histories as avenging or retaliating against insults towards women $(1.1-5,1.7-12,1.61,3.3,3.50$, and 5.92 to name but a few examples). The most widely known of all Greek wars, the Trojan War, was initially caused by the capture of Helen by Paris. This action, according to Herodotus (1.1-3), was inspired by a series of previous abductions of Io, Europa, and Medea.

${ }^{114}$ Rihll (1993) 79.
} 
of the Sabine Women'), these actions were justified on the basis that this was a traditional method used by the Greeks for acquiring wives. ${ }^{115}$

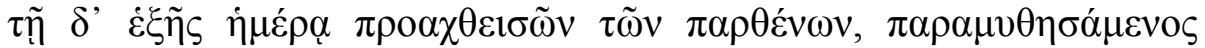

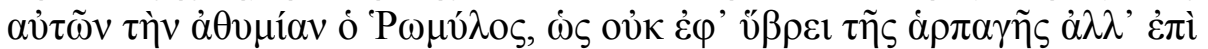

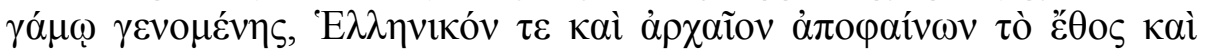

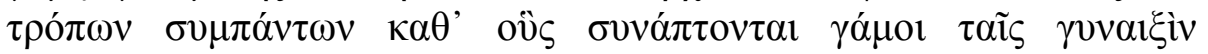
$\dot{\varepsilon} \pi 1 \varphi \alpha v \varepsilon ́ \sigma \tau \alpha \tau o v$.

The next day, having brought forward the maidens, Romulus comforted them in their despair, as they had not been seized out of wanton violence but of becoming wedded. He pointed out that this was an ancient Greek custom and that of all methods of contracting marriage for women, it was the most distinguished.

Greaves has suggested that: "it may be not a marriage ceremony that was the Greek tradition which Romulus adopted but rather the violent abduction of wives as part of an act of colonization". ${ }^{116}$ Livy's (Ab Urbe 1.9.14-15) account records how Romulus approached his neighbours to ask for rights of intermarriage so that he could ensure Rome's future beyond the current generation. ${ }^{117}$ When they refused, he arranged to trick the Sabine women to come into the city to watch the Consualia games where they were seized by the men. ${ }^{118}$

sed ipse Romulus circumibat docebatque patrum id superbia factum, qui conubium finitimis negassent; illas tamen in matrimonio, in societate fortunarum omnium civitatisque, et quo nihil carius humano generi sit, liberum fore.

But Romulus himself went around them [the women] and explained that the pride of their parents had caused this deed, when they had refused their neighbours intermarriage, but that, they would be in a state of marriage, in a partnership of all fortunes and citizenship, and, what is dearer than anything to the human race, this would be a free union. ${ }^{119}$

Violence associated with the act of marriage was not uncommon. For example, Plutarch (Lycurgus 15.3), reports how the Spartan marriage ceremony involved the

\footnotetext{
${ }^{115}$ Greaves (1998) 572. See cover image for a graphic representation of this event by JacquesLouis David, painted in 1799. I am not suggesting that this event was necessarily historical, however, the perceived attitude conveyed through the myth about the Greeks' behaviour is interesting to note.

${ }^{116}$ Greaves (1998) 573.

${ }^{117}$ Van Compernolle (1983) 1042 suggests that Livy draws upon a Greek colonial tradition.

118 rapio, rapere meaning 'to seize' rather than 'to rape' which is the terminology normally given to the story (OLD sv. rapio).

${ }^{119}$ This suggests that it was not a mixed marriage, per se, but a legally valid partnership resulting in citizen children.
} 
formal capture of the wife by the bridegroom. ${ }^{120}$ The myth about the abduction of Persephone by Hades is commonly referred today as 'the Rape of Persephone', and can be seen to establish the archetype of marriage as being synonymous with violence and sexuality. ${ }^{121}$ Pindar (Pythian 9.1-60) describes the rape of the nymph Cyrene by Apollo. This tradition is often described as symbolising the Greek colonisation of the city by the same name. ${ }^{122}$ From this variety of sources, we can be fairly certain that the Greeks were not averse to intermarriage.

\section{Intermarriage versus taking Greek wives}

Early modern scholarship, however, was frequently reluctant to acknowledge that Greeks abroad might have interacted, let alone intermarried, with the local populations, beyond engaging in warfare. ${ }^{123}$ The few that did proffer it as an option seemed to feel the need to apologise for the Greeks' behaviour. For example, Gwynn in 1918 excused intermarriage by citing extenuating circumstances due to remoteness, and stated that it was tolerable because there was an absence of skin-colour differences. ${ }^{124}$ Dunbabin in 1948 made allowances for intermarriage occurring in those colonies which had a mixture of Greeks from various parts of the mainland in them: "this might dispose them to hold less strongly to the traditions of their mother country.... and might also dispose them more readily to intermarry with the natives". ${ }^{125}$ With the rise of feminist and multi-cultural debates and theories in the later twentieth century, scholars began to acknowledge women and the possibility of intermarriage more readily (and

\footnotetext{
${ }^{120}$ Greaves (1998) 572-573 argued that there were strong similarities between Romulus' justification in the Rape of Sabines and the Spartan marriage ceremony. Although Plutarch wrote after Dionysius, it is possible that both authors had access to a common source which could account for the similarities.

${ }^{121}$ Dougherty (1993a) 63. Dougherty also points out the similarities in the depiction of marriage and death in the iconographic tradition of Greek vase painting. Indeed, as a process, marriage can be seen to follow Van Gennep's (1960) 'Rite of Passage' tripartite structure, that can also be applied to other passages in life such as birth or death (see Morris (1992) 9-10). Marriage generally can be interpreted as a method of integration of two people - the $\alpha v \alpha \kappa \alpha \lambda v \pi \tau \eta \dot{\rho} \rho 1 \alpha$ where the groom lifts the bride's veil and sees her face for the 'first' time marks how marriage as a ritual brings together two strangers (see Sissa (1990) 94-99; Oakley \& Sinos (1993) 25).

${ }^{122}$ Dougherty (2001) 132 .

${ }^{123}$ In his preface to The Western Greeks, Dunbabin (1948) vi wrote "I am inclined to stress the purity of Greek culture in the colonial cities" thus demonstrating his reluctance to recognise any indigenous influence in the colonies.

${ }^{124}$ Gwynn (1918) 109: "For in every sphere of their colonising activity, the Greeks met races which, though socially and intellectually their inferiors, were still, in feature and colour, of the same general type."

${ }^{125}$ Dunbabin (1948) 186
} 
reasonably), although frequently their assertions were not supported by any evidence. ${ }^{126}$ Those who do use evidence typically call on one of two passages from Herodotus, depending on whether they are arguing for or against intermarriage. However, as we will see, neither passage is capable of swaying the argument decisively one way or the other.

The first passage of Herodotus (1.146) is interpreted as evidence in favour of intermarriage: ${ }^{127}$

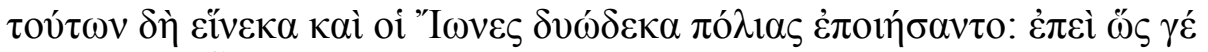

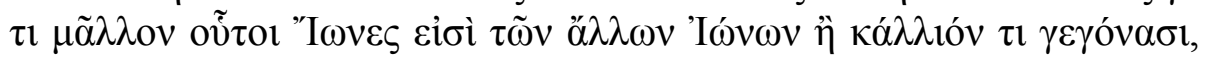

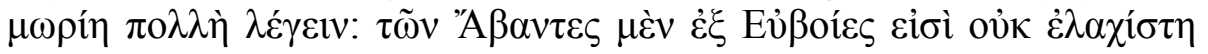

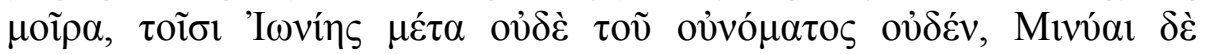

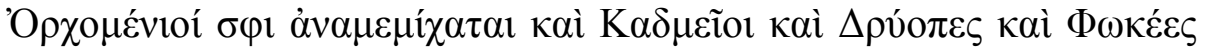

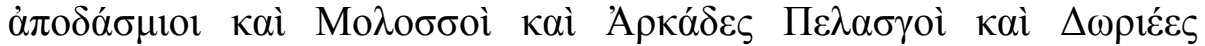

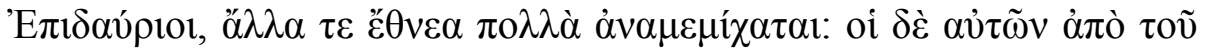

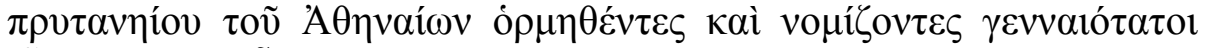

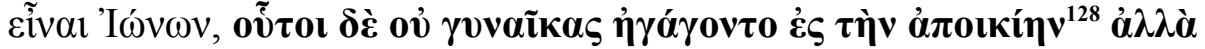

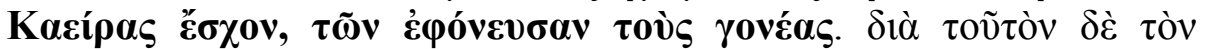

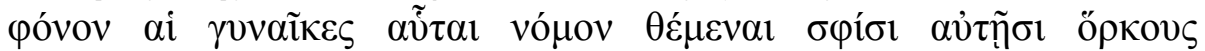

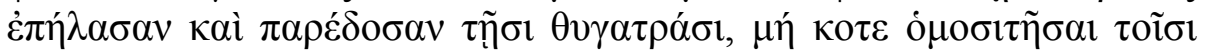

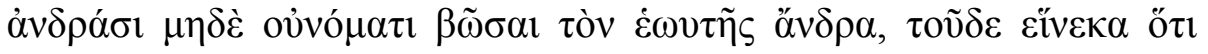

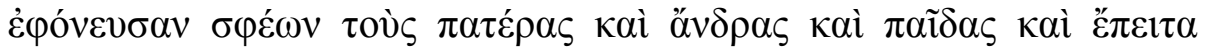

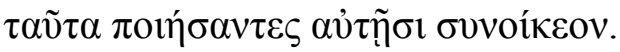

For the following reason, the Ionians built twelve cities. It is foolish to say that they did so because they are more Ionian than other Ionians, or in some way better born. The Abantians from Euboia are not the least part of the Ionians, and don't even have the name of Ionians. The Minyae of Orchomenus have mixed with them, and the Cadmeians, and the Dryopes, and the breakaway Phocaeans, and the Molossians, and the Pelasgian Arcadians, and the Dorians from Epidauros, and many other nations are mixed together. As for those from the prytaneum of Athens, who think themselves to be the purest of Ionians, they took no women to the colony [of Miletus], but took Carian women and killed their parents. Because of this slaughter, the women made a law, swearing an oath, and handed it down to their daughters, never to take meals with their husbands, nor call their husbands by name, on account of the fact that they had killed their

\footnotetext{
${ }^{126}$ See for example, Finley (1968) 18: "it is hardly likely that an adequate number [of women] (if any) were brought from Greece"; Dougherty (1993a) 67: "there is little doubt that intermarriage took place, despite the reticence of the Greeks to mention it"; Freeman (1999) 70: "intermarriage with natives would have been inevitable if the settlement was to endure".

${ }^{127}$ See for example, Pomeroy (1995) 34; Hodos (1999) 66.

128 Herodotus' use of apoikia demonstrates the inconsistency and the fluidity of the concept discussed in the previous chapter.
} 
fathers and husbands and sons, and after they had done these things, they lived with them. ${ }^{129}$

This passage clearly describes the foundation of Miletus by Ionian settlers. The foundation of Miletus took place prior to the colonisation of the archaic period and therefore this evidence describes a practice from an earlier occasion. Furthermore, the passage can be interpreted as an aetiological story characteristic of Herodotean writing. The aetiological nature of the story is clearly demonstrated by the oddity of the tale requiring further explanation and justification. The assertion that the law was imposed and enforced by the women themselves and passed on to their own daughters gave Herodotus the necessary connection between the unusual customs which were practised in his own day and events which purported to have happened long before. In this way, Herodotus was able to link the two tales and use the aition to provide explanation.

While on the one hand, the very nature of an aetiological tale means that it cannot be taken as factual historical evidence and was certainly at least in part created to explain contemporary customs, on the other hand, it could be argued that the story presents elements of fact or general testimony about Ionian practices. This passage, Coldstream argues, was intended to demonstrate the extent to which the Ionians of Asia Minor were a considerably mixed population. ${ }^{130}$ With reference to women specifically, Graham recommends that we look for any indication in the words that Herodotus uses as to whether he perceived the actions of the Ionian

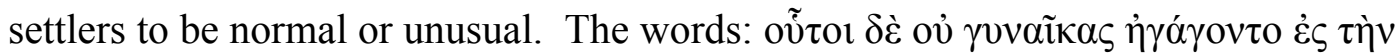
ámoıkí $v$ 'they took no women to the colony, but took Carian women and killed their parents', seem to "imply clearly enough that in Herodotus' opinion it was normal for colonists to take women with them". ${ }^{131}$ That is, Herodotus felt the need to mention that they did not take women in this case because that was contrary to customary practice. By itself, however, this one passage is not sufficient evidence to conclude that Greek colonists intermarried with the indigenous population.

\footnotetext{
${ }^{129}$ Pausanias (7.2.6) also reports this in his account of the foundation of Miletus; however it is likely that his work is based on Herodotus', as it includes the same information.

${ }^{130}$ Coldstream (1993) 98.

${ }^{131}$ Graham (1981-82) 294.
} 
The scholarship frequently uses another passage, also from Herodotus (1.164), as evidence against intermarriage, and in favour of the theory that Greek colonists took Greek wives with them: ${ }^{132}$

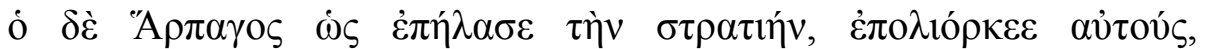

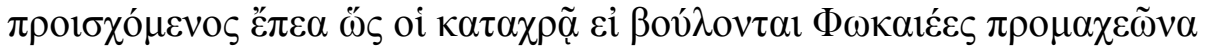

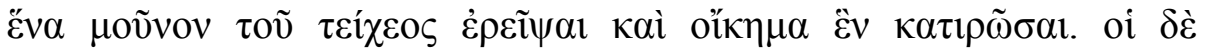

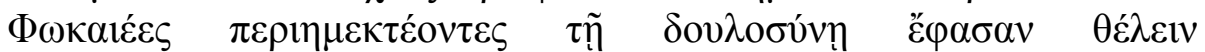

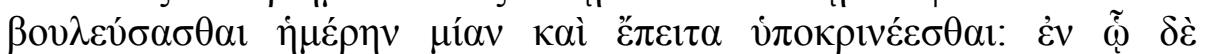

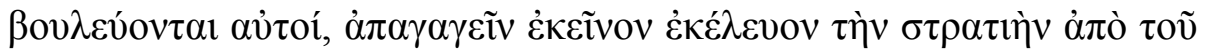

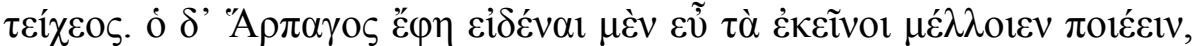

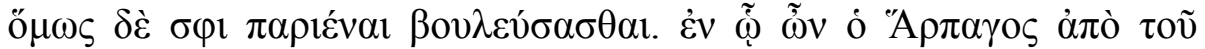

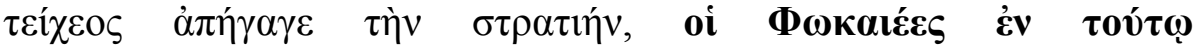

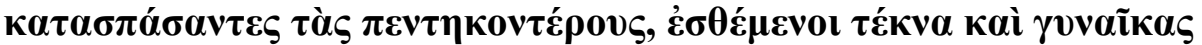

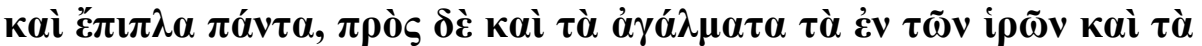

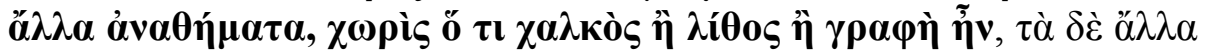

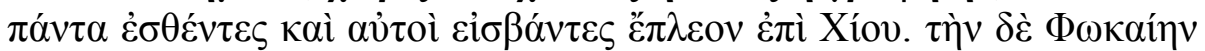

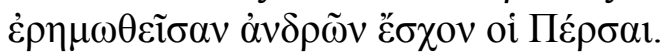

Harpagus, having driven his army against them [the Phocaeans] and besieged them, offered a proposal; that it would satisfy him if the Phocaeans were willing to demolish one battlement of the wall, and to consecrate one house. But the Phocaeans, aggrieved at the thought of slavery, said they wanted to deliberate for one day, and then they would give an answer. While they were deliberating, they asked him to withdraw his army from the wall. Harpagus knew what they were about to do, nevertheless, he allowed them to deliberate. While Harpagus led his army from the wall, the Phocaeans, in the meantime, pulled down the pentekonters, and put in the children, and women, and all moveable property, as well as the statues from the temples, and the other dedications, except for what was made of bronze, or stone, or painted, and once they had loaded everything else, they themselves embarked and sailed for Chios. The Persians took Phocaea, stripped bare of men.

This passage is the only one we have where women are specifically described as being present on the boat leaving to a new homeland. However, this passage in fact describes the total evacuation of the city of Phocaea in c. $540 \mathrm{BC}$ following the Persian invasion. ${ }^{133}$ The Phocaeans chose emigration over submission, wishing to avoid becoming Persian slaves or subjects. Therefore, the primary intention underlying the move to a new land (Elea in Italy) was to avoid enslavement and this drove the need for a complete evacuation and migration of the entire

\footnotetext{
${ }^{132}$ Graham (1981-82) 300. See also Hall (2004) 40 and Shepherd (1999) 270 who discuss this passage but discount it for the same reasons I do.

${ }^{133}$ Hall (2004) 80; Rouge (1970) 312.
} 
population. This diverges strongly from the usual practice of Greek colonisation, where instead of the entire population departing, the colonists were limited (in some way or another) to a smaller section or group of the population. Therefore, this evidence is not wholly applicable to colonisation, and should not be used as the sole basis of an argument against intermarriage or in favour of wives and husbands travelling together to found colonies.

\section{Conclusion}

In the second half of the twentieth century and continuing into the twenty-first, the weight of the scholarly opinion supported the view that only men founded colonies and therefore intermarried with indigenous women on arrival. Often, however, scholars asserted bald statements supported by little evidence. Alternatively, two passages from Herodotus are frequently called upon to argue for (1.146) or against (1.164) intermarriage. An examination of these two sources illustrates that neither source is capable of conclusively resolving the argument one way or another (despite many attempts to do so). 


\section{Chapter Three}

\section{A SURVEY OF SELECTED GREEK COLONIES: GREEK WIVES OR INDIGENOUS WOMEN?}

\section{Introduction}

This chapter examines ten different Greek colonies of the archaic period, grouped by region. The primary focus is on the foundation of these colonies with attention given to the first (or earliest) generation of colonists so that we might better establish whether Greek women were present from the outset, or whether intermarriage seems more likely. Where possible, both literary and archaeological evidence is considered hand in hand.

In addition to providing general background, a brief analysis of the various types of settlements as well as the reasons colonies were founded could help contribute to assessing whether women were taken on the initial voyage to found the colony. Thus, if a settlement was focused on trade above all else, how necessary would women have been (or at all, even once the settlement had become established)? If colonists set out with the specific intention of gaining land or resources, surely their settlement process would have been more territorially aggressive, and thus more like warlike conquests in which it would not be appropriate to involve women.

\section{Western Italy}

\section{Pithekoussai}

Pithekoussai, an island in the Bay of Naples, has been described as the oldest Greek colony in the Western Mediterranean. ${ }^{134}$ According to Strabo (5.4.9), it was founded in the eighth century $\mathrm{BC}$ by colonists from the two main cities on the island of Euboea: Eretria and Chalcis. ${ }^{135}$ The site has not revealed any Iron Age material which suggests that the island (or at least the area of settlement) was

\footnotetext{
${ }^{134}$ Buchner's (1966) article sets out to prove that Pithekoussai is the oldest Greek colony in the western Mediterranean. See also Hodos (1999) 61.

${ }^{135}$ Buchner (1966) 4.
} 
uninhabited prior to the arrival of the Greeks. ${ }^{136}$ The reasons behind Pithekoussai's foundation are not obvious. Further, there has been continued debate over whether Pithekoussai was an emporion, simply a trading station, rather than an apoikia. ${ }^{137}$ Pithekoussai could have been an island settlement that laid the groundwork for the establishment of Cumae on the mainland a generation later, as was a common practice for colonies in their initial years. ${ }^{138}$

Although the sites of the ancient town, cemetery, and acropolis were identified by a local scholar in the nineteenth century, controlled archaeological excavations did not begin until 1952. ${ }^{139}$ Intensive research was conducted by Giorgio Buchner for a number of years. Excavations began in the cemetery, and from very early on, it was apparent that the soil conditions at Pithekoussai have negatively affected the majority of the inhumed skeletons. Heat from thermal activity has reduced most bones to powder, ${ }^{140}$ so that scholars have been largely unable to carry out any osteological analysis, particularly cranial morphology which is a typical method of assessing gender. ${ }^{141}$

This has not deterred excavation of burial receptacles and grave goods. The main period of excavation ran from 1952-1961, and in that time, an area of approximately a thousand square metres was examined. ${ }^{142}$ However, this makes up less than $10 \%$ of the whole cemetery at San Montano, Pithekoussai. A total of 1,300 graves has been excavated, but information on only a portion of these, 723 , has been fully published. ${ }^{143}$ Furthermore, of the latter, only 493 are Geometric roughly a mere $2.5 \%$ of the total cemetery. ${ }^{144}$ To complicate matters further, to answer the question about the origins of women in Greek colonies, only very early graves should be examined (those potentially belonging to the first generation of

\footnotetext{
${ }^{136}$ Graham (1982) 99.

${ }^{137}$ See especially Ridgway (1973) 107-120; also Wilson (2006) 34; Cook (1962) 113-114; Graham (1982) 103; D’Agostino (1996) 535-536; Mertens \& Greco (1996) 243.

${ }^{138}$ Livy (8.22.5-6) claims that the colonists first settled at Pithekoussai, then moved to the mainland to establish Cumae, whereas Strabo (5.4.4) argues that a separate group of colonists left to found Cumae directly from Euboea. See Hodos (1999) 62; Graham (1982) 101.

${ }_{139}$ Becker (1995) 273-274; Buchner (1966) 5; Klein (1972) 34.

${ }^{140}$ Becker (1995) 273; Coldstream (1994) 51.

${ }^{141}$ Shepherd (1999) 276; Becker (1995) 276.

142 Buchner (1966) 5.

${ }^{143}$ These are published in Italian by Buchner \& Ridgway (1993). See also Boardman (1994) 95.

${ }^{144}$ Ridgway (1992) 101.
} 
colonists). ${ }^{145}$ How reliable might it be, however, to base a hypothesis on such a small proportion of the entire cemetery? ${ }^{146}$

Much of the focus of these excavations has been on the fibulae found in many of the graves. Women in mainland Greece are typically described as wearing the Doric peplos which was fastened with two straight pins holding the dress on each shoulder. These pins were usually made of bronze or gold (see Figure 2). The head of the straight pin was often extensively decorated. By contrast, the Italic ${ }^{147}$ fibulae found in the excavations at Pithekoussai, were made up of a pin, a hinge or spring, and a bow (see Figure 3). These fibulae resemble the modern safety pin. Like the straight pin, they were typically made out of bronze, iron, gold, or a combination of these. The bow provided an increased scope for decoration, and as such, was often inlaid with semi-precious stones, bone, or glass. These Italic fibulae can be divided up into several types: the leech, nevicella, and bone-andamber types are associated with females, while the serpentine type is associated with males. Examples of each of these types have been found at Pithekoussai.

The discovery of these Italic fibulae types at Pithekoussai was significant for two main reasons. First, no fibulae of the same form as those found at Pithekoussai have been found on the Greek mainland. ${ }^{148}$ Second, at Pithekoussai, so far only a total of 12 straight pins have been discovered. This suggests that the women who lived at Pithekoussai did not wear the Doric peplos that was common among the Greeks, and in turn, it has therefore been argued that those women were not Greek. ${ }^{149}$

Buchner's well known, widely accepted hypothesis reads:

\footnotetext{
${ }^{145}$ Ridgway (1992) 101-103 estimates that the total population of Pithekoussai in the late eighth century BC could have been between 5,000-10,000. If this was indeed the case, it suggests that there were both a relatively large number of colonists in the initial colonising party, as well as multiple groups joining the settlement. Osborne (1998) 258 argues towards a more mobile population model such as that of Naucratis, with a focus on profit and trade.

${ }^{146}$ This was one of the primary concerns of Coldstream (1993) 92.

147 These Italic fibulae have been found in Italy contemporary to those of Pithekoussai. See Toms (2000). Other fibulae types existed in Greece, but these were primarily used in votive contexts.

${ }^{148}$ Hodos (1999) 64.

${ }^{149}$ Hodos (1999) 69.
} 
It cannot possibly have been the men who set the fashion for indigenous personal ornaments...it must have been the women. It follows that most, if not all, of the colonists' women were not Greeks but natives - who were not prepared to abandon the haberdashery to which they were accustomed. ${ }^{150}$

This is too firm a conclusion for the evidence that we have. There is no source of metal anywhere on the island of Pithekoussai. Strabo (5.4.9) claimed that gold mines were present and that these were one of the initial motivating factors for the Euboean colonists to settle there. We now know that this is geologically impossible, and no other metal is found there either. ${ }^{151}$ However, Buchner's excavations of the area of habitation in the Mazzola area uncovered a number of significant buildings, connected in some way with metal working (see Figure 4). The building known as Structure III has been described as a blacksmith's workshop. Half was covered by a roof, with the other half acting as an open courtyard. The middle of this 'courtyard' appeared to be heavily burnt, which led Buchner to conclude that it was the site of a forge. ${ }^{152}$ Structure IV also has a forge, as well as a number of bits of iron and other metals which had accumulated in and outside the building. ${ }^{153}$ One of the most important finds in Structure IV was a miscast fibula (see Figure 5). This evidence suggests that these Italic fibulae were manufactured on Pithekoussai itself. ${ }^{154}$

The simple fact that there was no source of metal on the island, however, suggests that metal must have been sourced elsewhere and subsequently processed or manufactured into fibulae locally. This would have involved trade, which points to some sort of relationship between the Greek colonists at Pithekoussai and one or more indigenous populations in Italy, to enable the continued production of fibulae

\footnotetext{
${ }^{150}$ Buchner (1979) 135. This quotation comes from a later publication of Buchner's, slightly adapted from the original and translated into English (hence is the version I use here). His original hypothesis can be found in Buchner, G. (1975) 'Nuovi aspetti e problemi posti dagli di Pitecusa', 59-86.

${ }^{151}$ Cook (1962) 114.

${ }^{152}$ Buchner (1970-71) 66.

${ }^{153}$ Buchner (1970-71) 66.

${ }^{154}$ Buchner (1979) 135.
} 
locally. ${ }^{155}$ We cannot directly conclude from this, however, that intermarriage occurred at Pithekoussai.

I further question whether a mere sex-association is enough to draw the conclusion Buchner does; that is, because the fibulae were supposedly used by women, it was women who dictated the types used. A recent study by Shepherd of the fibulae has emphasised that they more commonly occur in the graves of children rather than adult women. ${ }^{156}$ She has also demonstrated that fibulae were often found in quantity, and as such could be considered as grave offerings rather than every day functional objects used with indigenous dress. On the basis of Shepherd's study, it is not possible to reach the same definite conclusion as Buchner. Clearly fibulae served not only a practical purpose, but could also be used as grave offerings. ${ }^{157}$ Furthermore, the accumulation of fibulae in some graves suggests that they could be interpreted more as indicators of class, status, or age than as markers of ethnicity or identity. ${ }^{158}$ Coldstream also suggests that a case could be made for Greek women "making do with what was locally available". ${ }^{159}$ This is certainly plausible, and again calls into question the problematic connection between object and ethnicity.

In the 1990s, Becker carried out various studies evaluating the sex of the deceased in the necropolis of Pithekoussai. ${ }^{160}$ He undertook a new approach which involved looking at the pieces of bone surviving the cremation process, coupled with objects associated with the burial, primarily grave goods and the type of

\footnotetext{
${ }^{155}$ Hodos (1999) 73.

${ }^{156}$ Shepherd (2005) 117. This study and Shepherd (1999) admittedly take into consideration fibulae throughout the Greek colonies, rather than those just at Pithekoussai. This is an important consideration, however, which will be discussed again.

${ }^{157}$ I acknowledge that fibulae were used in a votive way, even on mainland Greece, but in this thesis, I am solely considering fibulae in the context of the grave. Accordingly, I am assuming their practical use through their positioning relative to the deceased, so where pins were found on the shoulders, it is possible to conclude that the body was buried wearing the straight pins. This contrasts to graves where fibulae were found in multiple numbers and were not necessarily positioned on the body, and so in those instances, the deceased were almost certainly not wearing the pins, and accordingly it cannot be said they had a practical purpose but instead served another role as grave goods.

${ }^{158}$ Hodos (1999) 67.

${ }^{159}$ Coldstream (1993) 93.

${ }^{160}$ See Becker (1992) and (1995). 'Sex' and 'gender' tend to be used as interchangeable terms (as indeed is demonstrated by Becker). This, however, is incorrect. Sex is a biological category, genetically controlled, whereas gender is a cultural construct that can vary between social classes, as well as across time and space - a social identity. See Liston (2012) 127-128; Walker \& Cook (1998) 255-256; White \& Folkens (2005) 385.
} 
burial receptacle. An assessment of sex was first made solely based on bone analysis, and then again solely based on grave goods. Finally, both assessments were combined and compared. In the majority of cases, the two methods of sex analysis produced the same outcome: overall from these findings, Becker's study gave a sex ratio of adult males to adult females of approximately 40:60. ${ }^{161}$ It is not clear from his published work, however, whether the cremations analysed were linked only to the very early graves. Becker has proposed that this higher ratio of females to males could suggest a high incidence of polygyny or the presence of numerous female slaves, though certainly more research is required in this area. ${ }^{162}$ As we will see later, Pithekoussai is not the only colony where this sex imbalance exists in favour of women. Becker's study was hugely important for confirming the sex of those deceased, previously made solely on the basis of fibulae types.

Consistent with wider practice (particularly Etruscan), the serpentine fibulae found at Pithekoussai were (at least in the majority of cases) found with men. Interestingly, I have not yet seen any scholar suggest, in line with Buchner's hypothesis, that these could be indigenous men. Shepherd asks: "are these the offspring of a mixed society? Or do we have a case of indigenous wives organising their Greek husbands' wardrobes?"163 This further demonstrates the weaknesses of Buchner's hypothesis, and shows that inferring ethnicity and identity from objects is risky.

In the case of Pithekoussai, the archaeological discoveries have been interpreted as evidence of intermarriage. The plethora of Italic fibulae which were clearly manufactured locally from metal that must have been obtained by trade with other populations, are certainly an indication of Greek to indigenous contact. These have been used by Buchner to argue that, given their Italic type, they must have been used by Italic (and therefore indigenous) women. ${ }^{164}$ The strength of this reasoning, however, is weakened by several factors: only a small part of the cemetery has been excavated and so other graves may yet yield counter-evidence; in some cases the fibulae appear to be used as grave goods rather than explicitly to fasten clothing; finally, there are instances of fibulae being found in the graves of

\footnotetext{
${ }^{161}$ Becker (1995) 276.

${ }^{162}$ Becker (1995) 276.

163 Shepherd (1999) 294.

164 Buchner (1979) 135.
} 
children rather than adult women, adding to the argument that they were not necessarily items used only for a practical purpose. Therefore, although it is not possible to apply Buchner's hypothesis, there is not strong nor sufficient evidence that Greek women were taken to Pithekoussai either. On balance, it seems more likely that intermarriage occurred at Pithekoussai but we can in no way definitively conclude this from the present evidence.

\section{Sicily}

\section{Syracuse}

Syracuse, located on the eastern side of Sicily, was a colony of Corinth founded c. 734/3 BC. ${ }^{165}$ Thucydides (6.3.2) states that Archias, a Heraclid from Corinth, founded Syracuse.

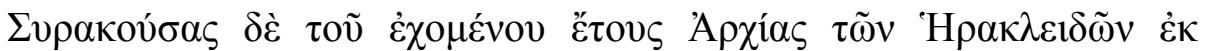

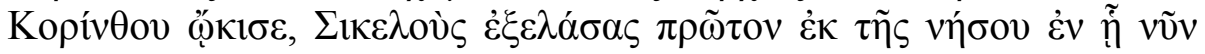

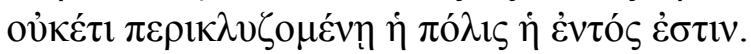

The following year, Archias of the Heraclids of Corinth, founded Syracuse, first driving the Sicels off the island on which the city is now, but is no longer surrounded by water.

This has been largely confirmed by archaeological excavation, where the first houses of the colonists have been found placed directly on top of the remains of the Sicel village. ${ }^{166}$ However, a Siculan hut was uncovered more recently which appears to have been in use in the late eighth century BC. ${ }^{167}$ This perhaps suggests that the expulsion of the indigenous Sicels may not have been as thorough as Thucydides suggests.

Thucydides makes very clear that the Sicels living on Ortygia, the offshore island of Syracuse, were driven away by the Corinthian colonists on their arrival. However, from Herodotus (7.155.2) it is evident that, at some time, many of these Sicels were also subjugated and turned into killyrioi:

\footnotetext{
${ }^{165}$ Shepherd (1995) 52.

166 Graham (1982) 105; Wilson (1981-82) 82. Sicily has three different indigenous populations (see Pseudo-Skylax 13.2) of which the majority appear to be the Sicels, occupying the eastern side of the island.

${ }^{167}$ Wilson (1987-88) 111.
} 


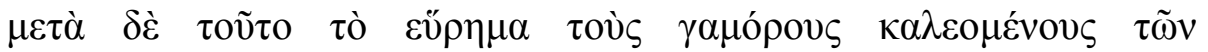

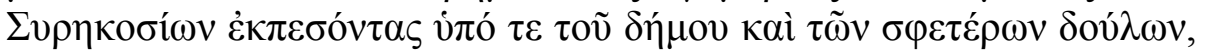

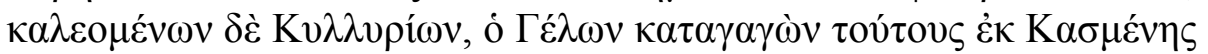

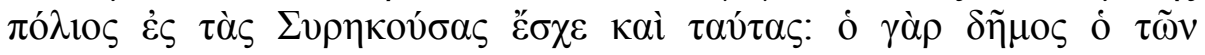

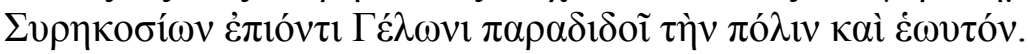

The gamoroi had been driven out by the demos and their own slaves, called the killyrioi. After this piece of good luck, Gelon led them from Casmene city into Syracuse, and took possession of it. For, the demos of the Syracusans surrendered the city and themselves to Gelon as he approached.

Herodotus reports on events in the fifth century BC when Syracuse was governed by a small group of landed aristocrats (gamoroi). Their slaves, the killyrioi, appear to have been the original indigenous population that was driven away by Archias (as mentioned by Thucydides above). As such, the killyrioi have been compared in status to the Spartan helots (that is, having an intermediary status between free men and chattel slaves), ${ }^{168}$ and probably also outnumbered their masters. ${ }^{169}$ Finley assumes (without citing any evidence) that some (female) Sicels were not subjugated, and instead were taken by the colonists as wives. ${ }^{170}$ Does this mean we should assume that some indigenous women were taken as wives and others as killyrioi? If so, how were the two differentiated? There is little evidence remaining on the killyrioi, so it is difficult to even begin to speculate.

For many years, colonies were assumed to have conformed with the same burial practices of their mother city. ${ }^{171}$ This followed the notion that each colony was designed as a mirror image of its mother city. ${ }^{172}$ In 1995, Shepherd produced an important sudy which demonstrated that Syracuse's burial practices departed

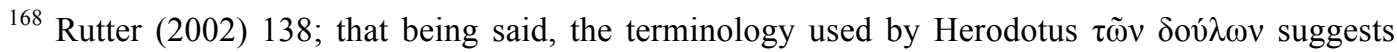
these people were more slave-like.

${ }^{169}$ Garlan (1988) 95. See also Aristotle Constitution of Syracuse (fr. 586 Rose), who compared killyrioi with the helots of Sparta, penestai of Thessaly, and clarotai of Crete. Garlan assumes that such 'rural slaves' existed in other colonies (Taras, Locri Epizephyrii, for example) though no evidence confirming their presence has been found.

${ }^{170}$ Finley (1968) 20. This argument shows evidence of the period in which it was written with no acknowledgment that seizing wives could be a form of subjugation. To simplify matters, I am assuming that Finley solely differentiates between the end result of a wife versus a slave.

${ }^{171}$ For example, see Holloway (1991) 64; Boardman (1980) 173.

172 Obviously this view did not take into consideration the various reasons why colonies were founded. It shows a clear influence of modern colonisation, where the British colonies, in particular, were designed as small slivers of Britain.
} 
radically from those of the mother city, Corinth. ${ }^{173}$ In the North Cemetery at Corinth, the Corinthians typically buried the dead (of all ages), contracted, in monolithic sarcophagi. ${ }^{174}$ This contrasts dramatically with the Fusco Cemetery in Syracuse, where Shepherd's study reveals that, "well over half the adult burials made in the first century or so of the colony's existence were not in monolithic sarcophagi, and the rate of use of the sarcophagus declines significantly in later periods, resulting in only a very small minority in the later sixth century". ${ }^{175}$ Instead, the deceased of Syracuse were typically buried in rock cut fossa graves, or trench graves, covered by stone slabs, though a variety of other methods were also used.

The reasons for these changes are not clear. There appear to be no practical (environmental or geological) reasons that could have prevented a continuation of mother city burial practices. ${ }^{176}$ Hodos argues that Syracuse was attempting to assert cultural independence from the mother city and a departure from familiar burial customs was one way to demonstrate such independence. ${ }^{177}$ This is not a particularly convincing argument without good reason for the colony to assert its independence (such as bad relations with the mother city or the exile of the colonists). Shepherd tentatively proposed that, for Syracuse and Corinth, the difference in burial methods could be explained if Syracuse retained the burial method that had been used previously (in the Geometric period) at Corinth. ${ }^{178}$ This lack of consistency could also suggest that the colonists may not have solely originated in Corinth, and instead, brought with them burial practices of their own cities. To complicate matters further, it is not even possible to argue that the colonists borrowed burial customs from their indigenous neighbours due to the fact that these differed in tradition yet again. ${ }^{179}$

\footnotetext{
${ }^{173}$ Shepherd (1995) 52-56. Shepherd's study argues that the burial practices of colonies generally were not the same as their mother cities. She uses three colonies, Syracuse, Megara Hyblaea, and Gela to demonstrate this.

${ }^{174}$ Shepherd (1995) 52. This method was used from the eighth to sixth centuries.

${ }^{175}$ Shepherd (1995) 54.

${ }^{176}$ To the contrary, Shepherd (1995) 55 points out that Syracuse has an excellent stone supply so it would have take very little effort to continue using sarcophagi, had the Syracusans wanted.

${ }^{177}$ Hodos (1999) 68.

${ }^{178}$ Shepherd (1995) 54.

${ }^{179}$ Hodos (1999) 68.
} 
In the Fusco cemetery, infants' graves have been found in the tombs of the assumed first (or earliest) generation colonists. ${ }^{180}$ There are a number of possibilities for this: that the indigenous population was still within the settlement and therefore these people and their infants could be buried within the same cemetery; that Greek women and children also accompanied the male colonists to the settlement; or possibly that intermarriage had occurred and these were the children of Greek men and indigenous women. One example in particular, in seemingly the earliest recorded tomb, revealed a child's burial, together with a Greek Geometric amphora, and a small bronze horse. Holloway has suggested that considering such objects were usually votive offerings, the child was probably that of an aristocratic Greek. ${ }^{181}$ The presence of children in a cemetery can be taken as an indication that women were certainly present.

Other discoveries in the cemeteries have included the bodies of many (apparent) women who were buried with two straight pins on their shoulders. ${ }^{182}$ If we were to follow Buchner's argument, discussed earlier with regard to Pithekoussai, this would surely indicate that these women wore the Doric peplos and that they were therefore Greek women in traditional dress. ${ }^{183}$ However, a few instances of fibulae of Italic types, associated with indigenous women, have also been discovered in some of the graves. ${ }^{184}$ By contrast, these pins were not found at the shoulders of the deceased and so a practical purpose seems less likely; rather they appear to have solely served the role of grave offerings. ${ }^{185}$ Furthermore, many of these fibulae occur in the graves of juveniles, or in a few graves of adults (sex undetermined), seemingly serving as replacements for the straight pins. ${ }^{186}$ It is therefore very difficult to reconcile these findings with Buchner's theory about indigenous women, proposed with Pithekoussai in mind.

Graham attempted to solve this problem by stating: "it seems clear that the manufacture of these objects in the West was quickly so organized that even for Greek men, or for a population that certainly contained Greek women, the only

\footnotetext{
${ }^{180}$ Holloway (1991) 51.

${ }^{181}$ Holloway (1991) 52.

${ }^{182}$ Graham (1981-82) 301

${ }^{183}$ Buchner (1979) 135

${ }^{184}$ Graham (1981-82) 301; Lorimer (1950) 338; Shepherd (1999) 227.

${ }^{185}$ Lorimer (1950) 338.

${ }^{186}$ Graham (1981-82) 301.
} 
fibulae and other metal personal ornaments available were those of Italic type". ${ }^{187}$ We cannot be sure that Syracuse 'certainly contained Greek women', largely for the same reasons as were raised in the analysis of Pithekoussai. The simple fact that fibulae were found in the graves of children weakens any argument linking them to women alone. Instead of being indicators of ethnic identity (whether indigenous or Greek), it seems more appropriate to regard the fibulae as markers of age and class. A source of metal for the Syracusan fibulae (albeit few that they are) has not yet been discovered, nor indeed have many areas for metal working. ${ }^{188}$

Drawing firm conclusions about the evidence in the cemeteries is more difficult because of the early date of the excavation of Syracuse. Syracuse was one of the many sites uncovered by Paolo Orsi, the 'godfather' of Sicilian excavation, in the late nineteenth century (1891-1895). ${ }^{189}$ Excavation methods have changed significantly since then and more emphasis has been placed on examining, retaining, and cataloging every single thing that is uncovered. Typical for his period, Orsi regularly discarded bones that were uncovered, so that later analysis using updated or new technologies is now not possible. ${ }^{190}$ Furthermore, analysis was primarily based on the grave goods found, which required drawing correlations between goods 'meant' for women, children, and men. More recent excavations have demonstrated that such assumptions are dangerous. For example fibulae, which women were assumed to have used solely in a practical sense (in a grave context), also appear to have been markers of wealth or status for children, and some men, as well as also serving these functions for women. As a result, our knowledge of Syracuse is more limited than perhaps we might expect.

It is difficult to reach an overall conclusion about Syracuse. The literary evidence gives us limited insight into the supposed banishment of the indigenous population, though it is also clear that many were subjugated. Other evidence rests heavily on archaeology, in particular the departure from mother city burial

\footnotetext{
${ }^{187}$ Graham (1981-82) 301.

${ }^{188}$ Hodos (1999) 73 argues that some metal working must have taken place in these colonies to obtain and maintain weapons and other tools, which have not yet been discovered. The metal was almost certainly sourced from other indigenous populations. The lack of a source of metal is an issue throughout Sicily.

${ }^{189}$ Lorimer (1950) 338.

${ }^{190}$ Shepherd (1999) 283; Angel (1972) 97. Indeed, Liston (2012) 126 points out that Kurtz \& Boardman's (1971) foundational study, Greek Burial Customs, lacks entries in the index relating to 'skeleton' or 'body', illustrating the relatively recent shift in importance.
} 
practices. As at Pithekoussai, fibulae have been found though in conjunction with the discovery of the straight pins. A plausible explanation is that the fibulae were indicators of class or status, but if that is the case, there is little to support arguments either way about the women who lived in Syracuse and were buried with them. The discovery of an early child burial, potentially of an aristocratic Greek, is strong evidence pointing to the presence of Greek children and therefore Greek women. But this is only one example, however, and so little can be concluded about the practices of the wider population. Accordingly, for Syracuse the evidence is inconclusive as to whether intermarriage took place.

\section{Megara Hyblaea}

Megara Hyblaea in Sicily was founded by colonists from Megara in c. 728 BC. ${ }^{191}$ It is not entirely clear why the colony was founded, in part due to the limited knowledge of the mother city, Megara. De Angelis has suggested that Megara Hyblaea was founded during a period of significant territorial change. The synoecism that seems to have ended the Megarian monarchy in the mid-eighth century $\mathrm{BC}$, and the loss and recovery of land referred to in the epitaph of the Olympic victor, Orsippos of 720 BC, both indicate that the period was one of great change and transformation. ${ }^{192}$

Thucydides (6.4.1-2) describes the many tribulations that the colonists endured, making various unsuccessful attempts to settle before they reached their final destination:

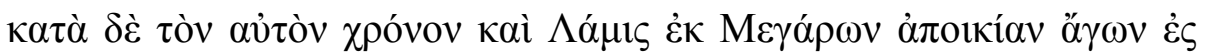

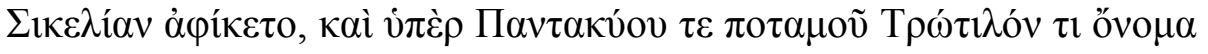

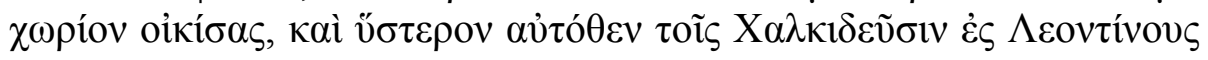

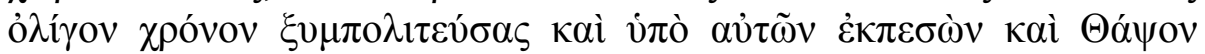

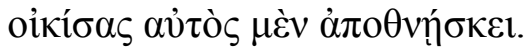

At this time, Lamis arrived in Sicily leading a colonial party from Megara. He founded a place called Trotilus on the river Pantacyas, and later, for a short time, they lived as fellow citizens with the Chalcidians at Leontini. Having been driven out by them, he founded Thapsus and then died.

${ }^{191}$ De Angelis (2003a) 12. Thucydides (6.4) states that the settlement at Megara Hyblaea existed for 245 years before being destroyed by Syracuse. From Herodotus (7.156), we are able to work out the destruction would have fallen between 485-480 BC. Working backwards from here, we get a foundation date of c. 728 .

${ }^{192}$ De Angelis (2003a) 47-48. See $I G$ vii 52 for Orsippos’ epitaph inscription. 
Throughout the many vicissitudes faced by the colonists, they were led by their oikistes, Lamis. However, Thucydides also reveals that Lamis died at Thapsus shortly after its foundation. An archaeological exploration of this area by Paolo Orsi brought to light an area of cemetery, with one grave in particular situated at a higher level. This grave contained two skeletons, two Corinthian Late Geometric cups, and a pair of bronze tweezers. ${ }^{193}$ It has been suggested that this could be the grave of Lamis himself, due to the dating of the grave to the same period coupled with the evidence in Thucydides about the location of Lamis' death. ${ }^{194}$ It has further been suggested that the second body in the grave could be that of Lamis' (Greek) wife. ${ }^{195}$ This could be interpreted as evidence that the colonists from Megara brought wives with them rather than intermarried with the local population.

Such an interpretation is very problematic. Like Syracuse, Megara Hyblaea also suffers from early excavation in the late nineteenth century when there was little importance placed on the analysis of bones. ${ }^{196}$ The skeletons in Lamis' supposed grave have long been discarded, therefore there is no way of carrying out any sex analysis on the bones. We can merely postulate that in cases where there are two bodies in one grave, they are frequently husband and wife, and so this grave in Thapsus may also fit this model. However, even this is problematic. If the grave is indeed that of Lamis, it seems unlikely that his wife would have died shortly afterwards (or before) to allow her to be buried in the same grave as her husband before the colonists moved on to their final destination of Megara Hyblaea. In addition, if we take into consideration the status that an oikistes appears to have held, it does not seem probable that Lamis would have been granted such a simple burial going by the accompanying grave goods. ${ }^{197}$ These are complicated issues for conjecture, but ultimately, the example of a single, prominent figure is not sufficient evidence to sustain a conclusion that Greek wives accompanied all (or

\footnotetext{
${ }^{193}$ Graham (1982) 106; Graham (1988) 309.

${ }^{194}$ Graham (1982) 107.

${ }^{195}$ Graham (1988) 310.

${ }^{196}$ Graham (1981-82) 299.

${ }^{197}$ As was discussed in Chapter One, the oikistes became the central figure of a founder-cult, and accordingly was worshipped as a hero after his death and accorded burial in a prominent place in the agora (see Wilson (2006) 25). For example, Pindar Pythian (5.92-5) claims that Battus was buried at the edge of the Cyrenaean agora and was worshipped as a hero. For more, see Malkin (1987); Dougherty (1993a). Of course, as was pointed out in the introduction, it must be acknowledged that there are many exceptions to these rules.
} 
some of) the colonists travelling to Megara Hyblaea. Furthermore, it is possible that the assumed Greek wife was sourced en route to Thapsus, for example at the temporary settlement Trotilus, and thus was not Greek at all. ${ }^{198}$ The series of foundations leading up to the ultimate colony of Megara Hyblaea create such implications for our interpretation of the evidence.

The site of the final settlement, Megara Hyblaea, gives an indication of the relationship between the colonists and Sicels. Often, as is the case for Cumae (Pithekoussai), Syracuse (Ortygia), Cyrene (Platea), to name just a few examples, colonists are more comfortable first settling on an island before moving to the mainland. This appears to have been so that the colonists could assess the indigenous population from an easily defensible place, before they negotiated or forced their way onto the mainland. By contrast, Megara Hyblaea was founded on the mainland from the outset, on a site which is low lying and has no natural defences. Therefore, it seems likely that the site can only have been settled with the permission of the neighbouring indigenous population. ${ }^{199}$

This hypothesis is further confirmed with evidence from Thucydides (6.4). $\mathrm{He}$ states:

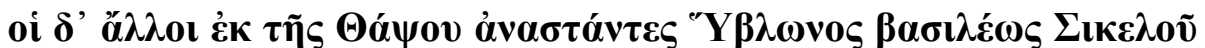

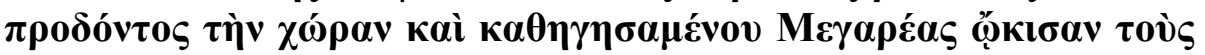

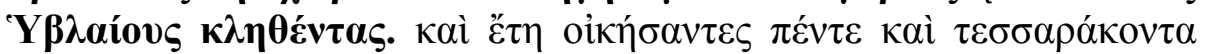

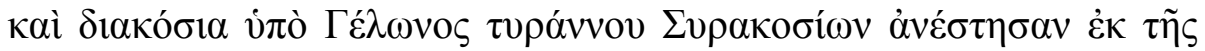

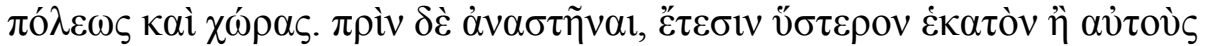

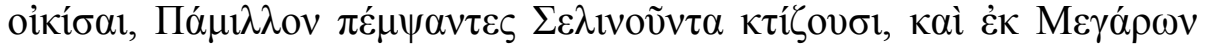

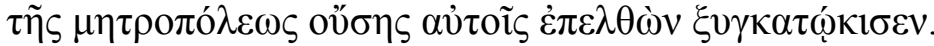

But the others were forced to leave Thapsus ${ }^{200}$ and they founded the place called Hyblaea. Hyblon, the king of the Sicels gave the Megarians the land and he led the way. They lived there for 245 years, before they were compelled to migrate from the city and land by Gelon, the tyrant of Syracuse. Before this happened, 100 years after they founded there [Hyblaea], they sent Pamillus, who had come from the mother city Megara to join them in colonising, and founded Selinus.

\footnotetext{
${ }^{198}$ This is a hugely important point that Graham $(1982,1988)$ overlooks.

199 Shepherd (1999) 290.

200 Thucydides does not make clear who drove the Megarian colonists from Thapsus, but we can

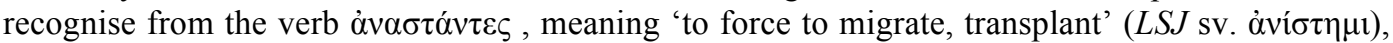
that they were indeed expelled. De Angelis (2003a) 13 believes that it was Syracuse who drove the Megarian colonists away. DeVoto (2005) 90 assumes that the Megarians submitted to the Sicels at Thapsus.
} 
No evidence in archaeological examinations has revealed any Sicel settlement on the site prior to the arrival of the Megarians. ${ }^{201}$ Therefore, the colonists were not compelled to drive out the indigenous population, which would have put a strain on the relationship between local and immigrant population. It is feasible, then, that good relations existed between the Greek colonists and the indigenous Sicels, and that these were conducive to opportunities for intermarriage. Relations between the two peoples were, perhaps, so good that the settlement, Megara Hyblaea, gained its name from the Sicel king Hyblon. Supporting this idea, Malkin has put forward an interesting theory that because of the death of the oikistes Lamis, the Sicel king Hyblon helped fill this role. ${ }^{202}$ The language used by Thucydides supports this interpretation, with the verb $\kappa \alpha \theta \eta \gamma \varepsilon$ co $\mu \alpha$ meaning to 'act as a guide' or to 'lead the way'. ${ }^{203}$ At the very least, the Sicel king had good relations with the Greek colonists, and Hyblon's relations with others can probably be extended to encompass the peoples over whom he ruled (that is, the neighbouring Sicels). Of course, good relations were not imperative to intermarriage taking place, but if they were good, there is a stronger chance that it could have occurred.

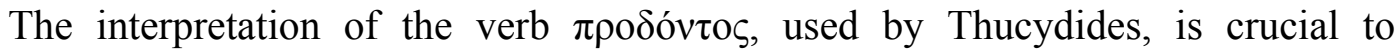
understanding the relationship between the Megarian colonists and Hyblon. Like many Greek words, the verb $\pi \rho \delta^{\prime} \delta \omega \mu \mathrm{t}$ can be translated in a number of different ways, and in this instance, the interpretation can significantly change the implications of the action. ${ }^{204}$ Graham argues that $\pi \rho \circ \delta i \delta \omega \mu$ should be translated in its most commonly used capacity, meaning 'to betray, forsake'. ${ }^{205} \mathrm{He}$ argues that Thucydides, probably personally, considered the transference of land from indigenous to Greek hands a betrayal, due to the recent hostility in neighbouring colonies against the Sicels (Syracuse and Leontini) in a strictly Greek versus Sicel approach. Graham also suggests that Hyblon could have belonged to a larger Sicel alliance against the Greeks which he betrayed, or more specifically that Hyblon

\footnotetext{
201 Shepherd (1999) 290.

${ }^{202}$ Malkin (2002b) 220.

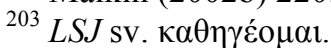

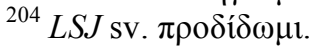

${ }^{205}$ Graham (1988) 311-313. Graham cites other uses of the verb (Xenophon, Hellenica 1.5 .7 and Polybius 31.27 .5 ) where he argues they should too be translated as 'to betray'. Malkin (2002b) 220-221 agrees with Graham's translation as 'to betray'. Neither scholar, however, discusses what sort of betrayal Thucydides implies.
} 
betrayed his own people. These suggestions are problematic. It does not seem possible to interpret the betrayal as that of Hyblon betraying his own people,

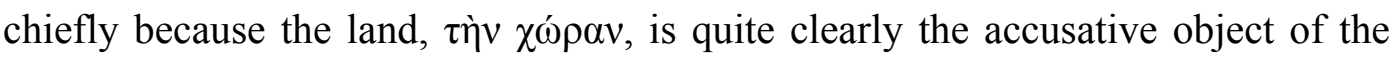
verb, 'betray'. Therefore, it seems unlikely that the verb, $\pi \rho \circ \delta i \delta \omega \mu$, should be translated as 'to betray'.

Alternative translations of $\pi \rho \delta \delta i \delta \omega \mu$ include 'to pay in advance' or simply 'to give to'. Paying in advance suggests that Hyblon gave the colonists the land as a part of a negotiated deal whereby the colonists would gain the land and would agree not to subjugate the Sicels. On the other hand, giving the land implies that Hyblon simply handed the colonists the land. ${ }^{206}$ Taking into account the fact that neighbouring Sicels had been driven off their lands at Syracuse and Leontini, it seems curious that Hyblon would give away land to a people he knew had caused problems for his neighbours. ${ }^{207}$ For that reason, it seems more likely that an offer of land was a precaution on the part of Hyblon. Of course there are many limitations to such a conjecture. We cannot be sure of the numbers of Greek colonists (as discussed in Chapter One) and even less so, the numbers of Sicels connected with Hyblon. Consequently, we cannot argue one way or another as to whether Hyblon was able to drive the colonists away and chose not to. Furthermore, we cannot rule out the option that friendly relations between the two peoples existed for their own sake.

An examination of burial sites of Megara Hyblaea has, like Syracuse, demonstrated that not all colonies followed their mother city's burial practices. Shepherd conducted a study in 1995, and although she freely admitted that there was little accessible information about the relevant date of the burials of Megara, it appears that they did not differ greatly from those of Corinth - and so these were used as an alternative comparison. ${ }^{208}$ In this period, the burial practices of both Corinth and Megara typically used slab-lined cist graves and monolithic

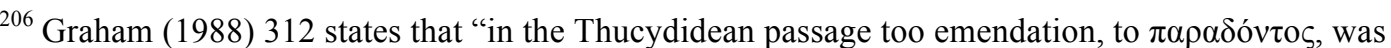
tentatively proposed by Classen in his first edition (Berlin, 1875). It is unfortunate that later editions promoted the emendation into the text, and that they were followed by the Loeb edition." Clearly, therefore, Classen thought that 'to give, hand out' was a valid reading (obviously Graham disagrees with this).

${ }^{207}$ Admittedly, we do not know the exact location of Hyblon's throne, but Megara Hyblaea is only 20 kilometres from Syracuse, so it would be highly unlikely that Hyblon was not aware of the consequences of the presence of other Greek colonists in Sicily.

${ }^{208}$ Shepherd (1995) 56.
} 
sarcophagi. By contrast, at Megara Hyblaea inhumation or cremation in amphorae was the usual burial practice. ${ }^{209}$ This could therefore indicate that the colonists were influenced by their indigenous neighbours, and adopted local practices for their own. It could also imply that some Sicels joined the Megarian colonists in settling at Megara Hyblaea, bringing with them indigenous burial practices. Again, there is no apparent reason which could have prevented a continuation of mother city burial practices. Therefore, this change was likely a conscious decision. Interestingly, by about the second half of the seventh century $\mathrm{BC}$, there seems to have been a revival of mother city practices, especially with monolithic sarcophagi, and vessel burials became less common. ${ }^{210}$ Any influence from the mother city in this change seems unlikely (unless there was a massive influx of new Megarian colonists), so perhaps the change came as Megara Hyblaea had become more settled and was beginning to prosper, and burial was just one way in which citizens could demonstrate their prosperity. ${ }^{211}$ Certainly in other Sicilian colonies the use of monolithic sarcophagi appears to have become more and more an elite burial type and thus a good indicator of wealth and status. ${ }^{212}$

Comparing evidence from Megara Hyblaea to another colony discussed earlier, Pithekoussai, brings an interesting difficulty in the interpretation of this evidence. Buchner's explanation for the fibulae found in the cemeteries draws a correlation between the origin of the fibulae and the origin of those who possessed them; that is, fibulae of Italic types must have been used by indigenous women. ${ }^{213}$ The various problems with this conclusion have already been outlined. If this hypothesis is applied to Megara Hyblaea, it becomes even more problematic. Though not all of the burials at Megara Hyblaea have been fully published, very few fibulae have been found. ${ }^{214}$ By contrast, straight pins occur much more

\footnotetext{
${ }^{209}$ Shepherd (1995) 56.

${ }^{210}$ Shepherd (1995) 57.

211 Shepherd (1995) 59. Shepherd reaches this conclusion by directly comparing the burial practices of Megara Hyblaea with Syracuse. This theory seems convincing, given that a certain amount of competition and hostility existed between the two colonies, before Syracuse destroyed Megara Hyblaea completely in 485-480 BC.

${ }^{212}$ Shepherd (2005) 118.

${ }^{213}$ Buchner (1979) 135.

${ }^{214}$ Shepherd (1999) 290-291. At the date of publication, Shepherd states that only 20 fibulae had been uncovered.
} 
frequently, with a total of 156 discovered and recorded in publication. ${ }^{215}$ In addition, the pins were usually found in pairs, and were located on the shoulders of the deceased, suggesting they served a practical purpose rather than acting solely as grave offerings. If Buchner's hypothesis from Pithekoussai is applied here, it would appear that the women of Megara Hyblaea were almost entirely of Greek origin rather than Sicel. This, however, is difficult to reconcile with the literary evidence (particularly of Thucydides) which implies that the colonists had unusually good relations with the indigenous population (though of course, this does not necessarily mean that intermarriage occurred). Therefore it seems that the presence of fibulae is no more an argument for intermarriage than the presence of straight pins is against it. Furthermore, as not all the straight pins belong to the same date (as indeed not all the fibulae do), it is entirely possible that by even the sixth century BC, ethnic distinctions may have been less apparent. Such a comparison further highlights the problematic nature of basing a theory of intermarriage on any single type of object found. It also demonstrates that when a hypothesis seems plausible for one colony, it is not necessarily possible to extend it to others.

The final crucial point to note for Megara Hyblaea is that around the mid-seventh century BC, a little under a century after foundation, the indigenous sites within the surrounding area were abandoned. This is particularly noticeable at Pantalica and Villasmundo. De Angelis suggests that this phenomenon indicates demographic transfer; either the indigenous populations moved away altogether, or they moved into the urban centre of Megara Hyblaea, and were subsumed into its population. ${ }^{216}$ The indigenous influences within the site, coupled with the evidence discussed from Thucydides, support the likelihood that the indigenous populations surrounding Megara Hyblaea became included among the colonists.

There is some evidence to support an argument that the colonists who settled in Megara Hyblaea were accompanied by Greek wives. The possibility that Lamis and his wife were buried in the same grave on their journey from Megara to the new colony, as well as the discovery of a higher proportion of straight pins in the

\footnotetext{
${ }^{215}$ Shepherd (1999) 291. As above, the number 156 was correct at the date of Shepherd's publication.

${ }^{216}$ De Angelis (2003a) 54.
} 
graves than Italic fibulae, lend support for this interpretation. These are not strong arguments, however, and the weight of the evidence, notably good relations between the colonists and the indigenous population (or at least between the colonists and Hyblon) set out in the literary tradition, and the apparent integration of two groups living within the settlement within 100 years of establishment, support the view that intermarriage was highly likely.

\section{Morgantina}

Morgantina lies almost at the geographical centre of Sicily, about 48 kilometres north of the south coast and about 54 kilometres inland from the east coast. ${ }^{217}$ The settlement is located on a steep ridge, approximately three kilometres in length, known today as Serra Orlando, with the main settlement located on the so-called Cittadella to the east of Serra Orlando. ${ }^{218}$

Both Strabo (6.1.6) and Dionysius of Halicarnassus (Antiquitates Romanae 1.12.3) relate the foundation myth of Morgantina, according to which the founder of the settlement was a man named Morges (after whom the settlement was more than likely named). Pliny (Natural History 3.10) describes how the settlers were from Bruttium, though according to an analysis of pottery and masonry styles, the settlers were from Catana or Leontini, settling c. 560 BC. ${ }^{219}$ As such, Morgantina does not have a mother city per se, but instead should be considered as a secondary colony. The settlement has a long history of occupation, from the Iron Age, right down to the first century AD. ${ }^{220}$ This, coupled with the fact that the town lacks an orthogonal plan, suggests that colonisation of Morgantina was a more gradual process and may not have taken place through a formal act of foundation. ${ }^{221}$

The first controlled archaeological excavations were conducted by Paolo Orsi in 1912, and have been continued at a number of different stages by various people and groups since. The majority of tombs were uncovered in 1969-1970 as part of the Princeton University excavations. The Princeton University team established that the most common tomb type in the archaic period was the chamber tomb,

\footnotetext{
${ }^{217}$ Eikeland (2006) 121.

218 Tsakirgis (1995) 123.

${ }^{219}$ OCD $^{4}(2012) 968$.

${ }^{220}$ Lyons (1996b) 177.

${ }^{221}$ Eikeland (2006) 126.
} 
accounting for $67 \%$ of the total burials. ${ }^{222}$ The fossa grave was the next most common; a rectangular trench surrounded by a shallow ledge, covered by terracotta roof tiles or stone slabs. ${ }^{223}$ Children were typically inhumed in fossa graves; adults could also be buried in fossa graves, though these tended to be more modest burials with very few grave goods accompanying the burial. Therefore, the majority of burials at Morgantina fit within an indigenous burial tradition.

The Princeton University study acknowledged that many of the burials at Morgantina had been disturbed particularly by grave robbers during the initial excavation and cleaning of the chamber tombs making them difficult to assess. Furthermore, Sjoqvist recorded in his Preliminary Report of the Second Season of Excavation that many of the tombs had flooded, with water causing objects to float around, thus upsetting them from their original placement. ${ }^{224}$ Despite this, archaeological examinations of the graves have revealed a curious mixture of cultural features. For example, one burial reveals a Greek-style sarcophagus found inside a traditional Sicel chamber tomb. ${ }^{225}$ In another example, within Tomb 4, one burial presents a Greek burial rite - a cremation with an ash urn sunk into a pit in the rock - but the ashes from the cremation were collected in a Sicel vessel. ${ }^{226}$ Such a mixed typology of the tombs supports an interpretation of Greeks and Sicels living side by side, with both peoples using the necropolis. This view is reinforced by the fact that there was no segregation between the various tomb types or burial rites used; that is, different areas of the cemetery were not restricted to one burial type, but instead all were mixed in together. ${ }^{227}$

The grave goods also give this impression; again, a diverse mixture of finds has been revealed. There are four main kinds of archaic pottery: Attic imports, late Corinthian imports, indigenous Siculo ware, and finally a Siculo ware which imitates Attic forms. ${ }^{228}$ This mixture of indigenous Siculo and Greek Geometric pottery could be a further indication of the Sicels and Greeks living side by side. On the other hand, it is easy to imagine that Sicels themselves could have used

\footnotetext{
${ }^{222}$ Lyons (1996a) 15.

${ }^{223}$ Lyons (1996a) 21.

${ }^{224}$ Sjoqvist (1958) 158.

225 Shepherd (2005) 117.

${ }^{226}$ Sjoqvist (1973) 35.

${ }^{227}$ Lyons (1996a) 179.

${ }^{228}$ Eikeland (2006) 94; Sjoqvist (1958) 156.
} 
their own traditional pottery, together with Greek pottery, which they also found occasion to imitate. However, a closer analysis of some of the pottery gives a better indication that there probably was a Greek presence at Morgantina explaining the presence of Greek wares. Various items associated with drinking parties (symposia) were found in multiple graves, including those thought to belong to women. ${ }^{229}$ Eikeland accordingly suggests that women were also allowed to participate in symposia at Morgantina, while they were typically restricted to men (and hetairai) back in mainland Greece. ${ }^{230}$ The sheer number of drinking vessels found seems greater than an assortment of objects collected through trade and more likely to reflect an adaptation of Greek social practices. ${ }^{231}$ Other objects found include fibulae, jewellery, and weapons. Because many of the burials had been disturbed, it is difficult to assess whether the fibulae served a practical purpose, or were merely grave goods. Making a reliable assessment of jewellery finds is equally difficult.

Weapons are not commonly found in the cemeteries of the Greek colonies in the archaic period. Even in colonies already discussed which were founded amidst violence, such as Syracuse, there is a distinct absence of any weaponry in the cemeteries. This contrasts with indigenous Italic settlements where weapons are frequently found in graves. ${ }^{232}$ Morgantina is different again, with some weaponry being revealed. Most spectacularly, the Princeton University excavation identified a chamber tomb with two warriors buried in complete armour. ${ }^{233}$ Each warrior was equipped with a Corinthian-style helmet, greaves, and a sword. A large shield was also discovered within the tomb. The high quality of this weaponry is clearly an anomaly, though other bronze and iron weapons of varying quality have been

\footnotetext{
${ }^{229}$ Most bones uncovered in the excavations were in an extremely poor state of preservation, and due to the periodic opening and rearrangement of the tombs many of the bones were mixed together, with others not saved at all for later studies. Taking this into consideration, coupled with the fact that many of the grave goods had been shifted from their original location, it is difficult to make any definitive determinations of sex.

${ }^{230}$ Eikeland (2006) 94. Eikeland does not take into consideration that these objects associated with females could have also belonged to hetairai at Morgantina.

${ }^{231}$ Shepherd (2005) 117.

${ }^{232}$ Lyons (1996a) 109 admits that weaponry is found in indigenous necropoleis in abundance in the Iron Age, though it begins to decrease slightly in frequency in the seventh and sixth centuries BC. This could be because of an adoption and adaptation of Greek practices, which meant that burials with weaponry became less popular or common.

${ }^{233}$ Lyons (1996a) 109.
} 
found in other graves at Morgantina. ${ }^{234}$ Lyons has suggested that this weaponry, coupled with some significant deposits of jewellery, could point towards the existence of some sort of an elite class within Morgantina. ${ }^{235}$ This suggestion is further reinforced with the multiple findings associated with the symposium discussed above. Clearly, the burials and associated finds are very different from both indigenous and Greek practice. This makes it difficult to conclude one way or another whether the women found in some of the graves were likewise Greek, or indigenous.

The Princeton University study concludes that the diversity of evidence that is so apparent at Morgantina suggests an increasingly stratified community with access to a greater range of imported goods (hence the mixed nature of finds). ${ }^{236}$ If we agree with this hypothesis, does it mean that we turn away from a theory of intermarriage? Antonaccio argues in this vein, stating that neither an influential Greek population, nor mixed marriages would necessarily be required to explain the presence of Greek features at Morgantina. ${ }^{237}$ However, the sheer number of Greek objects lends itself more to the impression of an extended physical presence, than mere trade encounters. On its own though, this does not help clarify whether there were Greek women present in the settlement.

One important find from Morgantina was a piece of graffito, combining both Greek and Sicel elements - a Greek script and language used to record a Sicel name (Figure 6). ${ }^{238}$ In 1990, a single large sherd was discovered in a grave, making up part of the neck and rim of a black-slipped Laconian ware krater. ${ }^{239}$ The fragment is 18 centimetres long and 13 centimetres high which suggests that originally the vessel probably had a 38 centimetre diameter and stood about 30 centimetres in height making it a standard size. ${ }^{240}$ Both the vase shape and the forms of the letters incised suggest a date in the second half of the sixth century BC. ${ }^{241}$ A rare example of writing is recorded on the sherd, stating: $\kappa \nu \pi \alpha \rho \alpha \varsigma \varepsilon \mu 1$,

\footnotetext{
${ }^{234}$ It is likely that this weaponry was not used strictly for military purposes, but instead was used for hunting.

${ }^{235}$ Lyons (1996a) 109.

${ }^{236}$ Lyons (1996a) 133.

${ }^{237}$ Antonaccio (1997) 180.

${ }^{238}$ Antonaccio (1993) 352; Antonaccio \& Neils (1995) 261.

${ }^{239}$ Antonaccio \& Neils (1995) 261.

${ }^{240}$ Antonaccio \& Neils (1995) 265.

${ }^{241}$ Antonaccio (1997) 191.
} 
meaning "I belong to Kupara". The practice of naming objects was not uncommon; in other colonies there are the occasional instances of it, such as the well-known eighth century BC 'Nestor's Cup' of Pithekoussai. ${ }^{242}$ Antonaccio and Neils' study demonstrates that the Morgantina graffito employs a standard formula, with a name recorded in the genitive (indicating the owner or dedicand),

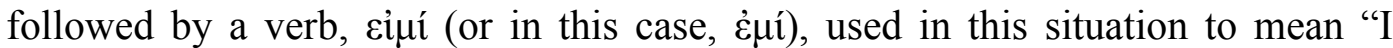
belong to so-and-so". ${ }^{243}$ Their study acknowledged that the - $\rho \alpha \varsigma$ ending was indeed the genitive of a $\alpha$-declension, and the owner was therefore likely to be a woman. $^{244}$

The name found on the fragment, Kupara, is not Greek. It does, however, appear to be a feminine name and is attested elsewhere in Sicily. For example, the name is paralleled on an inscription on a lead tablet in the north-west of Sicily, on a record discharging a debt of one archon and his children, Saiso and Kupura, to a goddess. ${ }^{245}$ Instances of the name Kupara are also found on what are probably votive offerings in a sanctuary at Terravecchia di Cuti. ${ }^{246}$ Kupara has also been attested in Syracuse as an alternative Sicel name for the spring Arethousa. At Syracuse she was personified as a nymph on coinage, and that same image has also been found on coinage in Morgantina during its period of Syracusan control toward the end of the fourth century BC. ${ }^{247}$ Therefore, it is possible that the Kupara on the Morgantina graffito was in fact dedicated to a nymph rather than belonging to an actual woman named Kupara. Although we cannot be certain either way, it seems less likely that the Kupara on the fragment refers to the nymph, given that the evidence (coinage) used to back up such a suggestion is from two centuries after the krater with the inscription was used.

The dating of this sherd in the second half of the sixth century BC seems to coincide with the beginning of a more significant Greek presence at Morgantina.

\footnotetext{
${ }^{242}$ 'Nestor's Cup' is significant for being one of the earliest inscriptions in archaic Greek alphabet, as well as being one of the few pieces of original poetry from the eighth century BC. It displays a verse inscription in three retrograde lines, stating: "Nestor's cup was fine to drink from. But whoever drinks from this cup will immediately be seized by the desire of fair-crowned Aphrodite." (translation: Graham (1982) 99). See Hansen (1976) for a general discussion on 'Nestor's Cup', and Watkins (1976) for a focused analysis of the inscription; also Malkin (1998) 156-158.

${ }^{243}$ Antonaccio \& Neils (1995) 268, 272.

${ }^{244}$ However, linguistically, a male owner is possible in the $\alpha$-declension.

${ }^{245}$ Antonaccio (1997) 181; Antonaccio \& Neils (1995) 269.

246 Antonaccio (1997) 181.

247 Antonaccio (1997) 181.
} 
While on the one hand, it would be easy to assume that this sherd was a clear indication of intermarriage (given the sherd belonged to an indigenous woman, Kupara), on the other hand, we must be mindful that there was already a very established indigenous presence at Morgantina, in addition to a minor Greek one, when the Greeks seem to have first arrived. Consequently, this sherd does not make it possible to definitively rule out the possibility that Greek wives accompanied the colonists to Morgantina, nor does it confirm that intermarriage took place. It does, however, further confirm that Greeks and Sicels coexisted at the settlement, and accordingly, it seems likely that intermarriage would have occurred (even if not straight away).

At Morgantina it is very difficult to firmly conclude whether the early colonial women were Greek or indigenous. To do this calls for distinguishing between a Greek settlement with a likely case of intermarriage and a settlement with a very high degree of Hellenisation. Certainly, the indigenous population had considerable contact with the Greeks and they appear to have lived side by side in a mixed community. The sheer number of Greek objects reinforces the impression of deeper contacts than simply trading encounters, and the evidence also points to Greek customs and practices being modified and taking on some indigenous characteristics. All of this suggests the possibility of intermarriage at Morgantina between Greek men and indigenous women.

\section{Southern Italy}

\section{Taras}

Taras, located in south-east Italy, was founded in c. $706 \mathrm{BC}$ by colonists from Sparta. It appears to have been one of very few colonies founded by Sparta in the archaic period. $^{248}$ Taras is located in the modern day Gulf of Tarentum and was situated between an inner and outer natural harbour. ${ }^{249}$ The site has been constantly occupied since indigenous habitation just prior to the establishment of the Greek colony, later becoming Roman Tarentum, then modern Taranto.

\footnotetext{
${ }^{248}$ Spartans tended to expand outwards into Messenia and the wider Peloponnese, rather than overseas.

${ }^{249}$ Astour (1985) 24.
} 
Consequently, extensive excavation work is almost impossible, so our knowledge of the site is heavily reliant on the literary tradition.

Tradition has it that the colonists concerned with Taras' foundation were known as the partheniai. Historians have concluded that these were probably the sons of Spartan women and helot men, who were illegitmate and born during the first Messenian war when the husbands of the women were away fighting. ${ }^{250}$ The motivating factors behind leaving Sparta and founding a new colony are not entirely clear. Malkin has postulated that because the foundation took place following the first Messenian war and seems to have involved non-integrated groups of Spartans (the partheniai), it is likely that some sort of stasis involving land and/or status was behind the foundation. ${ }^{251}$ The relationship between the partheniai as colonists and the Spartan state itself is therefore ambiguous. While on the one hand, the partheniai were apparently banished from the mother city almost as if they were a threat, on the other hand they were representing Sparta as a colony and, as Redfield puts it, were "to recapitulate Spartan experience". ${ }^{252}$ It is tempting to conclude that women accompanied the men to Italy given their compromised status. Clearly the label of the group as 'partheniai' suggests a separate status, and a status predicated on the female line.

Another curious aspect about the foundation story of Taras is the oracle given to the oikistes, Phalanthus, by the Delphic oracle, recorded by Strabo (6.3.2):

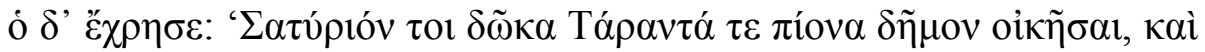

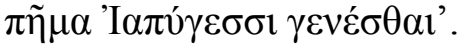

The oracle proclaimed: 'I gave both Satyrion and the rich land Taras to you to inhabit, and to be a calamity to the Iapygians'.

Not only does the oracle reveal the exact location where the colonists were to settle, but it appears to command Phalanthus to make war on the indigenous population, the Iapygians. Whether the oracle recorded in Strabo is authentic or

${ }^{250}$ Pembroke (1970) 1241; Brauer (1986) 3. Strabo (6.3.2-3) reports two different accounts. The first is of a fifth century BC Syracusan historian Antiochus; the second is of fourth century BC Ephorus of Cyme in Aeolia, Asia Minor. The two versions are relatively substantial (and so are not being covered here in any depth). They also differ in many aspects, especially regarding who the partheniai were. This is not important to my argument, but it is significant to observe that both versions make pertinent that the colonists (the partheniai) were not in any complete sense 'Spartans'. See Brauer (1986) or Pembroke (1970) for further explanation.

${ }^{251}$ Malkin (1994a) 141.

252 Redfield (2003) 293. 
not is irrelevant to this discussion; whether it was the answer to an enquiry at Delphi or was a fiction, it characterises the attitudes the colonists took to Taras. ${ }^{253}$

The oracle also states that the Spartan colonists first settled at Satyrion (modern Leporano) before they relocated to Taras. ${ }^{254}$ This has been confirmed archaeologically and excavations have revealed Greek material from c. 750 BC. ${ }^{255}$ As we go through each case study of each colony, it is becoming increasingly clear that it was common practice for colonists to settle on an island or another easily defensible place, so that they could assess the territory and establish relations (whether hostile or friendly) with the indigenous population.

Another interesting tale associated with the foundation of Taras is reported to us by Pausanias (10.10.6-8):

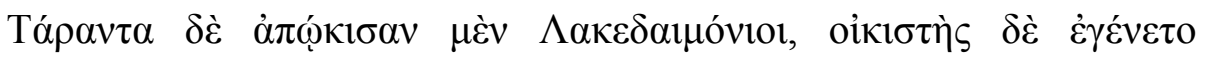

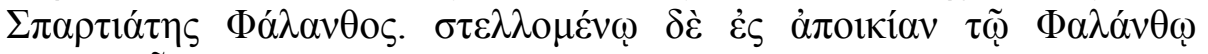

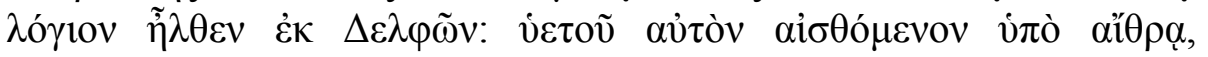

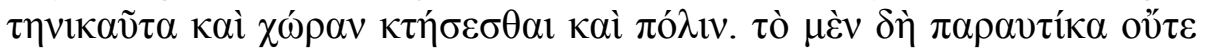

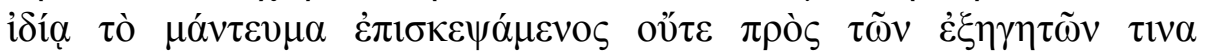

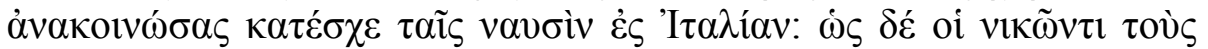

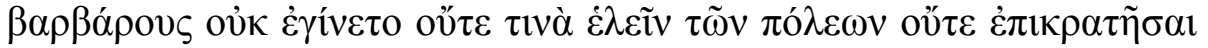

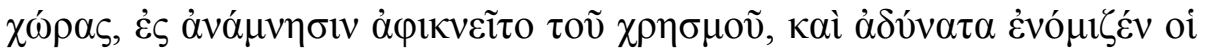

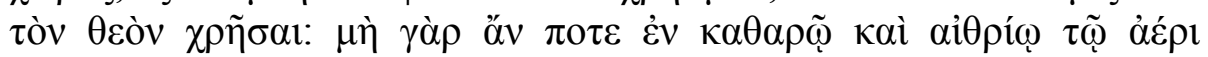

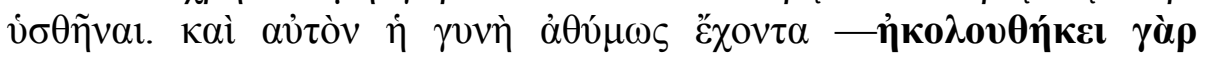

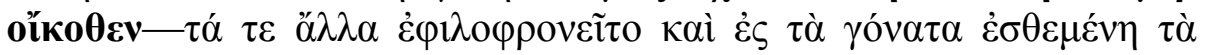

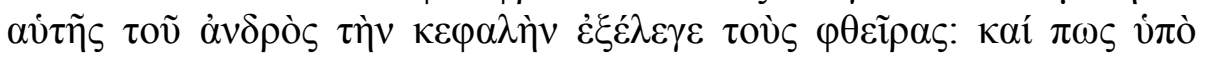

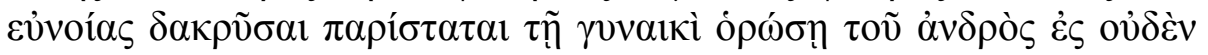

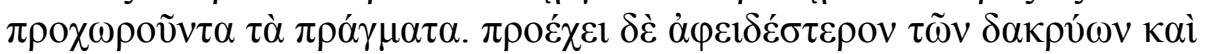

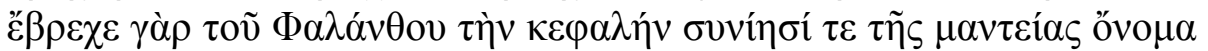

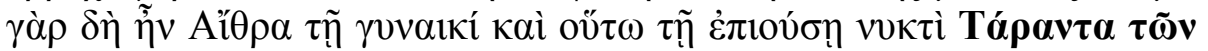

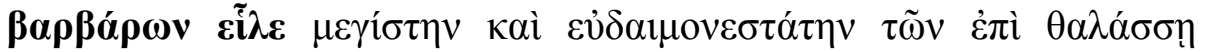
$\pi o ́ \lambda \varepsilon \omega v$.

\footnotetext{
${ }^{253}$ Malkin (1994a) 122. Malkin's discussion deems the oracle to be authentic; however he also recognises that, regardless, it can be seen as 'thematically authentic' in its reflection of early attitudes toward territory and the indigenous peoples. Graham (1981-82) 298-299 disagrees, and argues that "oracles of this kind are a notoriously concocted element in our traditions about colonial foundations, and this one must clearly be rejected as unhistorical." Shepherd (1999) 270 also argues that the narrative is so fabricated that the presence of a Greek wife is unlikely. Malkin (1994a) 126 further suggests that these attitudes contained in the oracle could simply be because Taras was a Spartan colony, and given their recent conflict with the Messenians, the same hostile attitudes were projected onto the new environment where territorial appropriation was necessary.

${ }^{254}$ Malkin (1994a) 121.

${ }^{255}$ Whitehouse \& Wilkins (1989) 105.
} 
Taras is a colony of the Spartans, and its oikistes was Phalanthus, a spartiates. When setting out for the colony, an oracle came to Phalanthus from Delphi, [declaring] that when he felt rain under a cloudless sky, he would acquire land and a city. At first he neither reviewed the oracle himself, nor consulted one of his advisors, but he continued to Italy with his ships. But although he conquered the barbarians, he neither seized any city nor ruled over any land. He called to mind the oracle and considered that the god proclaimed an impossibility. For it could never rain from a clear and cloudless sky. His wife, while he was dispirited - for she had accompanied him from home - treated him affectionately and placed her husband's head between her knees and picked out the lice. And out of affection, she cried seeing her husband's affairs coming to nothing. As her tears poured forth, she wetted Phalanthus' head, and then he understood the oracle, for his wife's name was Aethra. And thus on that night, he seized Taras from the barbarians, the largest and most wealthy city by the sea.

This passage about the foundation of Taras is well-known for the riddle it contains about 'rain under a cloudless sky'. More significantly, it also reveals, according to the tale, that the oikistes' wife, Aethra, accompanied him on his journey, and indeed that she played a crucial role in the foundation of Taras. This is comparable to the evidence discussed regarding Megara Hyblaea's founder, Lamis, and the grave that potentially contains his body and that of his own wife. On the other hand, however, it is not credible to extrapolate the evidence on the oikistes to every single colonist who took part in the foundation, just as the practices of monarchs or other minority groups cannot be used by themselves as evidence for the practices of the majority population. In other words, Aethra, because of the crucial role she plays in the foundational narrative, appears to have been an exceptional member of the colonial group. ${ }^{256}$ Even so, it is reassuring to note that there was a role for individual women. Furthermore, it is worth noting that the presence of women was not so unusual that Aethra seems out of place in the story.

An assessment of the likelihood of intermarriage at Taras is made extremely difficult by the fact that any conclusion is based almost solely on literary evidence. While the literary evidence for the foundation of the colony is very rich, our evidence of the early years of the colony after foundation is almost non-existent. ${ }^{257}$

\footnotetext{
256 Shepherd (2012) 220.

${ }^{257}$ Brauer (1986) 11.
} 
This makes it difficult to assess the practices of the colonists once they had settled into their new colony, and especially, their relations with the indigenous inhabitants of the area after 'being a plague' to them. Further, the literary evidence, particularly Pausanias (10.5-8), seems to have a solid foundation in myth and accordingly cannot be relied upon for its historicity. The dearth of any archaeological evidence also leaves us with little to justify and verify the literary evidence in the way it is possible to do (at least to a certain extent) in other Greek colonies.

If we solely consider the literary evidence discussed above, it appears that intermarriage was unlikely at Taras. The Spartan colonists seem to have driven out all the indigenous inhabitants, the Iapygians, on their arrival (though there was potentially opportunity for them to seize wives during this process). Furthermore, while there is evidence, albeit heavily grounded in myth, that at least one wife accompanied her husband, it does not speak to the practices of the other colonists. Her presence in the story does perhaps indicate that the presence of a wife or woman was not so unusual that she appears out of place. Accordingly, at Taras, it is very difficult to reach any firm conclusion about whether or not intermarriage occurred.

\section{Locri Epizephyrii}

Taras is frequently analysed alongside another southern Italian colony, Locri, or Locri Epizephyrii. This is primarily because the foundation myths of both colonies include women, which in turn aids consideration of the social function that women served in wider archaic society, and particularly colonial society. ${ }^{258}$

Locri was founded in c. $673 \mathrm{BC}$ by the Locrians of eastern Greece. The colony is located in south-eastern Italy, in the 'heel' close to Taras. The city is unique among Greek colonies in that it never appears to have had a proper name. ${ }^{259}$ Instead, the city, Locri, was named after the people who lived in it (oi $\Lambda$ oкроí). ${ }^{260}$ This contrasts with the usual practice where Greek peoples are named after their

\footnotetext{
${ }^{258}$ Greco (2006) 173.

${ }^{259}$ Pembroke (1970) 1250.

${ }^{260}$ Redfield (2003) 253.
} 
city (for example: the Corinthians of Corinth; the Athenians of Athens; the Thebans of Thebes).

Locri is especially significant as the literary tradition states that there were female settlers involved in the settlement process. Polybius (12.5.6-8) writes:

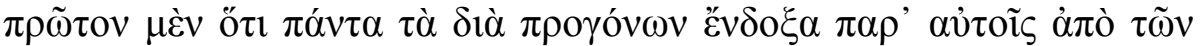

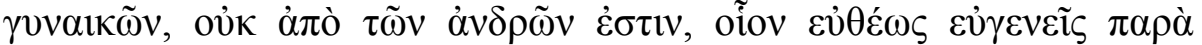

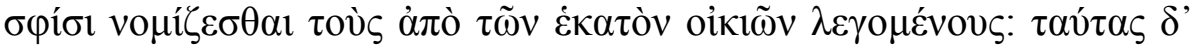

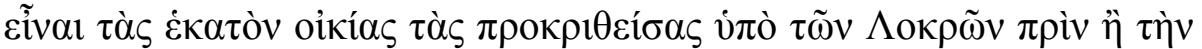

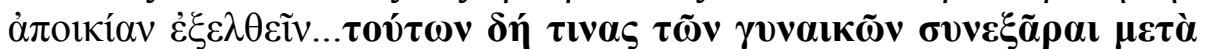

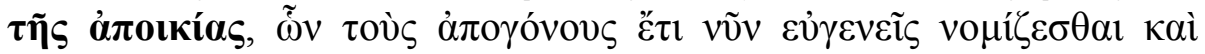

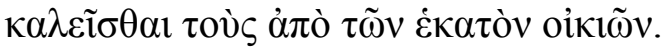

Firstly they said that all ancestral reputation comes through the female line not the male. These belonged to 'the hundred families', selected by the Locrians before sending out the colony...some of these women assisted in raising the colony, their descendants are still now thought to be noble and called the 'men of the hundred families'.

This passage describes the crucial role that women supposedly played in the foundation of Locri. These women were the bearers of the noble bloodlines of the so-called Hundred Houses, the leading families of Locris in Greece. Because the Locrians are reported to follow their descent through women, it has been argued that this narrative is a fabrication - possibly an aetiology dating to the fifth century $\mathrm{BC}$, probably created to explain the matrilineal succession of Locri. ${ }^{261}$ This tradition, therefore, is heavily rooted in myth and its historicity should not be taken as a given. However, the passage does show that there could have been potential for women to fulfill an important role. Whether their presence in this tradition was considered unusual or typical is unclear today.

Polybius (12.5.10) also states that, as in other colonies, the Locrians expelled the

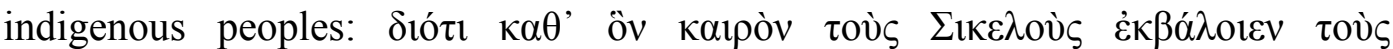

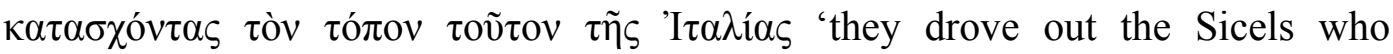
occupied this place in Italy'. It is not clear whether or not some indigenous women were kept for marriage and reproductive purposes, but it should not be ruled out.

${ }^{261}$ Shepherd (2012) 219; Pembroke (1970) 1252; Cawkwell (1992) 295; Hall (2004) 40. 
Locri has been excavated more extensively than Taras, yet the finds are of little use to our analysis. Locri (the cemeteries and sanctuaries in particular) were excavated by Paolo Orsi, beginning in $1890 .{ }^{262}$ As the excavation was so early, the excavation techniques were not as advanced as they have become, and as at other colonies such as Pithekoussai, Megara Hyblaea, and Syracuse, the bones from the graves were not considered important, and consequently, no attempts were made to determine the sex of the deceased. Furthermore, Orsi's excavations of Locri were not thoroughly published. For example, at the Lucifero cemetery, 1675 graves were excavated but only a mere 162 were published. ${ }^{263}$ As a result of this selectivity, the sex ratios of the deceased appear skewed. The majority of the graves published by Orsi were those which were perceived to have interesting contents (grave goods). These tended to be items such as toys, and objects associated with women, such as needle cases, mirrors, perfume jars, spindles, tweezers, or ointment boxes. As a result, it is difficult to use archaeology to further explore the issue of intermarriage at Locri.

Our understanding of the early settlement of Locri, as with Taras, relies overwhelmingly on literary evidence. The literary evidence has a solid base in myth and seems to have served as an aetiological tale to explain the matrilineal succession of Locri. Whatever the caveats, if such evidence is not contradicted by other material, the picture we have is that the Greek colonists included women as well as men and that the local population was driven away so that indigenous women were simply not available. This conclusion can only be, at best, tentative.

\section{Metapontum}

The Greek colony of Metapontum, modern Metaponto, was founded in c. $650 \mathrm{BC}$ by colonists from Achaia and Troizen in the northern Peloponnese. ${ }^{264}$ Located about 40 kilometres south west of Taras, the settlement covered an extensive area. The entire chora of Metapontum has been thoroughly assessed, aided by the fact

\footnotetext{
${ }^{262}$ Redfield (2003) 207.

${ }^{263}$ Redfield (2003) 220.

${ }^{264}$ Whitehouse \& Wilkins (1989) 106.
} 
that the ancient city was abandoned in the fifth century BC and never reoccupied due to an ongoing threat of malaria. ${ }^{265}$

Like the other South Italian colonies examined in this thesis, Metapontum's foundation myths are complicated and difficult to follow. Strabo (6.1.15) states that the Pylians, sailing home from the Trojan War, founded the city of Metapontum with king Nestor. He also records an alternative tradition whereby Metapontum was founded by an Achaian, Leukippus, who acquired the site through tricking the Tarantines. It is not imperative to analyse these foundation myths for the purposes of this thesis, but it is significant to note that the literary evidence does not allow for a specific group of Greeks to be identified as the 'first' Greeks in Metapontum. ${ }^{266}$ Carter believes that this is because the Greeks of Metapontum represented a variety of mother cities. ${ }^{267}$

The reasons for the foundation of Metapontum are not immediately obvious. Whitley points out that the settlement is not positioned near any trade routes, that it has only an average harbour, and is not situated near any natural resources which could have motivated Greek settlement. ${ }^{268}$ These factors, coupled with the knowledge that the Metapontine coin would later display an ear of wheat (symbolising agricultural prosperity), ${ }^{269}$ strongly suggest that Metapontum was settled simply to gain more agricultural land. It also seems to have been, at least in part, settled with the intention of preventing further Tarentine expansion southward. ${ }^{270}$

Metapontum was occupied prior to Greek arrival and the establishment of the colony. Mycenaean pottery has been uncovered suggesting that there was contact between the indigenous population and some Greeks (if not something more permanent) as far back as the fourteenth to thirteenth centuries BC. ${ }^{271}$ Greek pottery dating to the eighth and seventh centuries $\mathrm{BC}$ has also been discovered, though it is not clear whether there was a permanent Greek presence at this time,

\footnotetext{
${ }^{265}$ Carter (1998) 5; Carter (1981) 167.

${ }^{266}$ Carter (2006) 81. As such, Metapontum probably did not have a 'formal foundation' per se (see below).

${ }^{267}$ Carter (2006) 81.

${ }^{268}$ Whitley (2001) 125.

${ }^{269}$ Whitehouse \& Wilkins (1989) 115.

${ }^{270}$ Malkin (1994a) 121.

${ }^{271}$ Carter (1998) 6.
} 
and if there was, what effect it might have had on the indigenous population. ${ }^{272}$ The excavation of an Iron Age village at Incoronata (within Metapontum's chora) has demonstrated that the indigenous settlement certainly had extensive contact with Greek traders, and probably also had some Greek inhabitants living within it. ${ }^{273}$ When the Greek colonists arrived subsequently, the indigenous population and the earlier Greeks already appear to have been coexisting peacefully, and there is little reason to assume that this would suddenly have changed. If this was already the norm in the area, intermarriage was a definite possibility open to the colonists.

The Pantanello Necropolis within the chora of Metapontum demonstrates some unusual features. In particular, the focus of scholarship has centred on the skewed sex ratio: women outnumber men by $2: 1 .^{274}$ Biologically, males and females survive into adulthood in roughly equal numbers (taking into consideration exposure, death in warfare, death in childbirth, for example), so there must be another explanation for such an imbalance. ${ }^{275}$ One possibility is that men were buried in another, as yet unidentified, location away from their families. ${ }^{276}$ This skewed ratio has little relevance to the period of focus in this thesis; oligandria is given as a reason for the shortage of males in the cemetery, but this only became a problem in the fifth and fourth centuries BC, thus at least a century after the foundation. Carter states that in the initial period, c. 600-501 BC, the sex ratio seems to be $1: 1$, though he admits that the sample size is extremely small and so it is not possible to get an accurate result. ${ }^{277}$ Consequently, while this is interesting to speculate about, it is important not to get sidetracked and to acknowledge that this has little to do with solving the questions at the heart of this thesis.

Recently, intensive study from a scientific angle has been conducted on two of the populations within the chora of Metapontum (Pantanello and Crucinia). ${ }^{278}$ One study is of particular relevance, in which Henneberg assessed both the metric and

\footnotetext{
${ }^{272}$ Carter (1998) 6.

${ }^{273}$ Carter (1998) 6.

${ }^{274}$ Shepherd (2012) 226. This applied to individuals between the ages of 15 and 49 and from the period 500-301 BC (the majority of burials come from this period).

${ }^{275}$ Carter (1998) 145. It seems unlikely that half of every generation of males were consistently killed in warfare. See Carter (1998) 509.

${ }^{276}$ Carter (2006) 41-42; Shepherd (2012) 226.

${ }^{277}$ Carter (1998) 509.

${ }^{278}$ See Henneberg \& Henneberg (2001); Henneberg (1998).
} 
non-metric characteristics of teeth, and how these characteristics could be used as indicators of ethnicity and sexual dimorphism. ${ }^{279}$ In brief, the overall results of this analysis demonstrated that there was indeed a biological relationship between the Greeks living in Metapontum and the indigenous Italics, and that this relationship was more prevalent among those living within the chora of Metapontum than those living in the city itself. ${ }^{280}$ This suggests that intermarriage was more common in the country than in the urban environment. This could in turn indicate that some Greek women were present in the city to allow for the less pronounced combination of characteristics. We must recognise that this study looks at individuals not just from the period of foundation, but over a number of centuries. This still remains relevant, however, as it is possible to determine the extent of intermarriage over the years, and the evidence allows us to assume that intermarriage was also a feature of the earliest generations of analysis (the first generations of colonists).

At Metapontum, therefore, there was a long period of interaction prior to the archaic colonisation of the Greeks. After settlement there was a greater concentration of the newcomers in the countryside, easing their presence in a way that more forceful takeover in the chora might not.

\section{North Africa}

\section{Cyrene}

Cyrene is located in North Africa, modern day Shahhat - Jabal al Akhdar. ${ }^{281}$ The settlement was founded by colonists from Thera in c. $630 \mathrm{BC}$. Cyrene is one of the most well known of the Greek colonies, particularly due to an extensive discussion by Herodotus, who uses the Persian expedition to Libya in c. 514 BC as an opportunity to discuss his other knowledge of Libya. The foundation of Cyrene

\footnotetext{
${ }^{279}$ Henneberg (1998): that is, metric being physical measurements, and non-metric looking at other characteristics that may be present in teeth (for example, the Carabelli Cusp, or the so-called Etruscan upper lateral incisor). This study acknowledged that metric and non-metric characteristics could well be controlled by different genetic factors, or be influenced by various environmental factors, affecting results. See Carter (2006) 82.

${ }^{280}$ Carter (2006) 82-83.

${ }^{281}$ The area surrounding the settlement of Cyrene is frequently called 'Cyrenaica', but as Austin (2008) 187 (footnote 1) points out, this term is anachronistic for it was not used before the Augustan period. Herodotus (for example, at 4.199.1) uses the term 'Cyrenaea' to describe the territory of Cyrene.
} 
is particularly well documented, with Herodotus reporting two separate versions one of the Theraeans (4.150-153) and one of the Cyrenaeans (4.154-156) - as well as a fourth century BC inscription purporting to be the foundation decree. ${ }^{282}$ There are also a number of references to intermarriage in later source material.

Herodotus (4.151.1) reports the Theraeans' belief behind the impetus for the foundation of Cyrene:

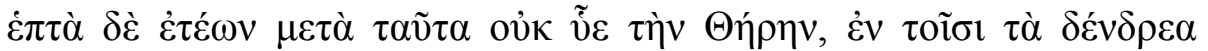

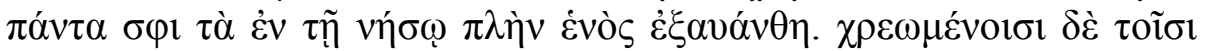

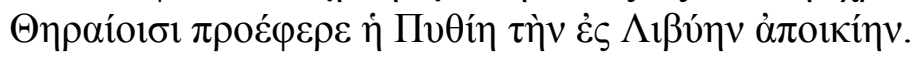

For seven years following this, there was no rain at Thera and in that time all the trees on the island, except one, dried up. The Pythia, who the Theraeans consulted, proposed a colony in Libya.

Herodotus clearly states that the Theraeans believed the colonists set out from Thera because of drought. If this was the case, it would be more likely that a cross section of the community would have left, including women, if not children as well, rather than just men alone. But as will be shortly discussed, there are few indications that women and children accompanied the colonists. Herodotus (4.156) tells us that in the Cyrenaean version of the story, when the colonists failed to settle in Libya, and attempted to return to Thera, the Theraeans refused to allow them back into the city, and indeed would not even let them land their boats. This indicates that the relations between the colonists and the Theraeans were frosty. Accordingly, if we are to follow the Cyrenaean version, it is more likely that there was some sort of stasis in Thera, and that a group (possibly led by Battus) was, in effect, exiled. This view is reflected in the scholiast to Pindar, Pythian Odes 4.10a (Menecles of Barca, FGrHist 270 F 6) where civil disruption caused the faction led by Battus to be driven from Thera.

\footnotetext{
${ }^{282}$ Osborne (2009) 12 argues that it is unsurprising that divergent accounts exist; it was advantageous for the Theraeans to uphold their links with their colony because it had become more prosperous than them (as the mother city). The Cyrenaeans, by contrast, had no reason to maintain links with Thera. Accordingly, Osborne argues "it is vain to seek historical truth from either account [in Herodotus]. Neither account was interested in a full and frank record of what happened; both parties were telling stories of the past to suit the present, stories that were not only selective in their memories but free in their elaboration." While I agree with this, I would add that the textual evidence of Cyrene is really no different from any other colony in that the historicity of these sources should not be taken for granted. Foundation tales, in particular, are heavily grounded in myth as the Greeks enjoyed speculating about their beginnings (see Dougherty (1993a)). It is also important to note that the Greeks did not necessarily distinguish between 'myth' and 'reality'.
} 
Herodotus (4.153) states that, accordingly to the Theraean version, the members of the colonising party were drawn by lot: ${ }^{283}$

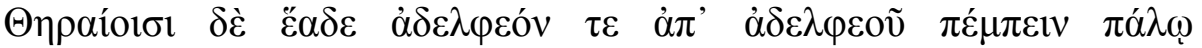

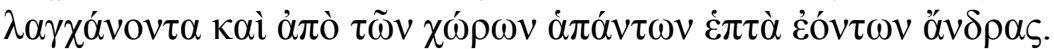

The Theraeans decided to send brother from brother, obtained by lot, men from all seven regions [in Thera].

Cawkwell argues that the position of the word óv $\delta \rho \alpha \varsigma$ in the sentence is emphatic and thus could be indicating that it was only men who went on the colonising expedition. ${ }^{284}$ The Foundation Decree of Cyrene (ML 5.27-30, or SEG 9.3.28$31)^{285}$ similarly states that:

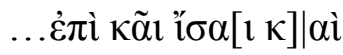

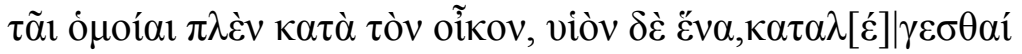

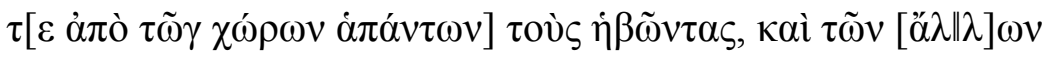

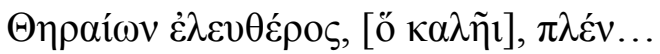

...They are to sail according to house, following both equal and similar terms, with one son picked out from each and free persons of the other Theraeans are to sail...

Although no mention is made of intermarriage in either source, Marshall has suggested that in line with the exclusively masculine nature of the colonisation implied in the sources, marriage with indigenous women was a fundamental part of the process of the foundation. ${ }^{286} \mathrm{I}$ am less convinced that such an argumentum $e$ silentio provides a full answer. That is to say, the lack of any mention of women does not necessarily mean that they were not involved in the process of foundation. ${ }^{287}$

While the colonists seem to have blundered their way through the foundation, spending their first two years on the island of Platea (Herodotus 4.157) and a

\footnotetext{
${ }^{283}$ This is the only instance I have identified where we are told exactly how the colonising party was selected. This could be because the Cyrenaean expedition was particularly well organised, while other colonising ventures were put together in a more 'hodge-podge' way.

${ }^{284}$ Cawkwell (1992) 291.

${ }^{285}$ This decree dates from the fourth century BC, but it appears to quote from the original seventh century BC decree of Thera on the foundation of Cyrene. There has been much debate about the authenticy of the decree, though this is not especially relevant to discuss here. See Austin (2008) 190. Also Graham (1960/2001) and Jeffery (1961) for discussion in favour of authenticity, and Dusanic (1978) for discussion against.

286 Marshall (2004) 128.

${ }^{287}$ Graham (1981-82) 301.
} 
further six years at a settlement called Aziris (Herodotus 4.158), their relations with the indigenous Libyans following this seem to have been friendly. The interaction between the Greeks (Cyrenaeans) and indigenous populations (Libyans) is made clear in a number of sources. Herodotus (4.189.1) presents this interaction as a two-way process stating, for example, that:

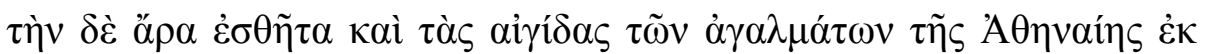

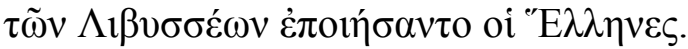

The Greeks copied the clothing and aegis of the statues of Athena from the Libyans.

In addition, Herodotus (4.189.3) also states that the Libyans taught the Greeks to harness and drive the four-horse chariot. ${ }^{288}$ On the other hand, Herodotus acknowledges that the Greeks taught the Libyans many things, and the adoption and adaptation of customs was mutual. ${ }^{289}$ The Libyan tribe, the Asbystae, for example, is marked out by Herodotus (4.170) in the way that their general way of life imitated that of Cyrene closely. Indeed, such was the relationship between the colonists and the Libyans that Herodotus (4.158) reports that the Libyans physically led the blundering colonists to the place of ultimate settlement. Admittedly, the Libyans seem to have ulterior motives for this action: they led the Theraeans in the dark so that they would be able to pass through the best parts of the country without them seeing it.

There is further literary evidence specifically pointing to a strong tradition of intermarriage between the Greeks and the Libyan women at Cyrene which may have begun at the inception of the colony. The third century $\mathrm{BC}$ poet, Callimachus, who came from Cyrene, claimed in his Hymn to Apollo (85-86):

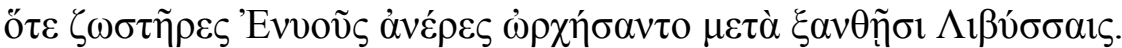

The warrior-belted men of war [the colonists] danced with the goldenhaired Libyans.

Scholars typically quote this short passage as evidence of some sort of interaction between the male colonists and the indigenous female Libyans (that could be

\footnotetext{
${ }^{288}$ Stucchi (1989) 83. Stucchi also analyses various representations of the quadriga in Cyrene, which back up the evidence in Herodotus, particularly their use as transport vehicles (rather than racing or war chariots).

${ }^{289}$ Applebaum (1979) 13.
} 
explained by intermarriage). ${ }^{290}$ However, prostitution could also account for the interaction described, or the passage could be a military reference.

Pindar's Pythian (9.105-125) also illustrates a tradition (albeit rooted in myth) of intermarriage in Cyrene. Pindar describes the marriage between the Cyrenaean Alexidamus and the unnamed daughter of the Libyan Antaeus. Many Cyrenaeans had come hoping to marry the girl. Antaeus decided to organise a race to decide which man would marry his daughter. She was placed on the finish line, and the first man to touch her robes would become her husband. Alexidamus won the race and the resulting wedding is described in order to glorify the city. This story not only reports this instance of intermarriage, but could also be symbolic of intermarriage between Cyrenaean men and Libyan women more generally. ${ }^{291}$

The late fourth century (321 BC) edict of Ptolemy I which established the constitution of Cyrene, proclaimed that the sons of Cyrenaean men and Libyan women should have full citizen rights (SEG 9.1.1-3). This demonstrates that by the late fourth century BC intermarriage certainly occurred commonly, and indeed occurred despite restrictions prior to the passing of the edict. On the other hand, however, it also suggests that prior to Ptolemy's constitution, intermarriage only produced non-citizens. Ptolemy's edict could also, perhaps, indicate a continuous tradition of intermarriage at Cyrene. This would appear to contrast with other Greek colonies, at least in terms of the limitations of scholarly discussion, where intermarriage is usually only suggested as a short-term solution to a lack of women, rather than an ongoing practice as is indicated in this edict.

In 1960, Rosenbaum conducted a study of Cyrenaean portrait sculpture, comparing distinctive features of Greek figures versus Libyan. For example, the features of CPS 1 (Figure 7), a Libyan man, are compared to non-Libyans CPS 188, 189, 190, 191, and 199 (Figures 8 and 9). ${ }^{292}$ These examples each have features obviously not conforming to Greek, Roman, or Egyptian ethnic types, such as tight curly hair, full lips, and high, prominent cheekbones, that are instead apparent in CPS 1. From this, Rosenbaum concludes that: "that we find these traits at all is a proof of

\footnotetext{
${ }^{290}$ Marshall (2004) 129; Graham (1981-82) 296; Murray (1993) 115; Rouge (1970) 316.

${ }^{291}$ Marshall (2004) 129; Cawkwell (1992) 291; Calame (1990) 302-303.

${ }^{292}$ Rosenbaum (1960) 21.
} 
the mixture of races that had taken place". ${ }^{293}$ Many of these busts, however, date considerably after the period of foundation. CPS 1 dates to the second half of the fourth century BC, while the majority of others (CPS 188, 189, 190, 191, and 199) date as late as the first century AD. Therefore, like the edict of Ptolemy I, these busts are good evidence for intermarriage occurring at these times but we cannot necessarily conclude that intermarriage took place between the Theraean colonists and Libyans at the time of the colony's foundation. A limestone relief, dating to the Hellenistic period, depicting a female deity and a pastoral scene, also combines a mixture of Greek and Libyan elements which "surely reflects the good relations between the Greek and native populations of Cyrene" (Figure 10). ${ }^{294}$ While both the busts and the limestone relief are far too late to be conclusive evidence of intermarriage occurring at the time of foundation, they are indicative of a continuous practice of intermarriage (also indicated by Ptolemy's edict, discussed above). On the other hand, however, conclusions based on physical features for 'racial profiles' are not necessarily sound.

Herodotus (4.186) describes how the women of Cyrene observed certain food taboos, which were the same as those in Libya. ${ }^{295}$

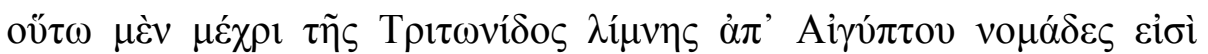

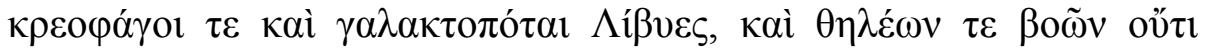

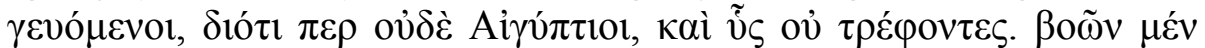

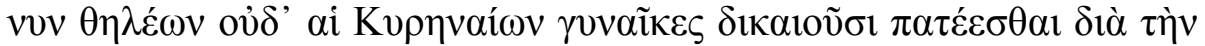

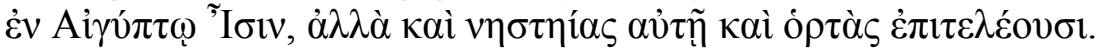

Thus between Egypt and the Lake Tritonus are Libyan nomads who eat meat and drink milk, though they don't eat cows nor rear swine, for the same reasons as the Egyptians. The women of Cyrene don't allow the consumption of cows because of Isis of Egypt, and also they honour her with fasts and festivals.

This, of course, appears as a retrospective aetiological tale, characteristic of Herodotean writing, to explain why such a practice would exist in his own time. Despite this, by the fifth century BC when Herodotus was writing, the custom, whatever its origins, must have been practised by enough Libyan women that they

\footnotetext{
${ }^{293}$ Rosenbaum (1960) 22.

${ }^{294}$ Wanis (1992) 41.

${ }^{295}$ Boardman (1980) 155; Van Compernolle (1983) 1044.
} 
were able to influence Cyrenaean religious customs applying to eating rules and taboos. ${ }^{296}$ The custom is clear evidence of cross-cultural contact.

Onomastic studies can further provide insight into the relationship between Cyrenaeans and Libyans. The occurrence of a significant number of Libyan names in Cyrene's inscriptions suggests, firstly, that the Libyans were integrated within Cyrenaean society, and secondly, that the Cyrenaeans and Libyans did indeed have close relations with one another, possibly including intermarriage. ${ }^{297}$ We should be mindful however, as Laronde puts it, "not everyone with a Libyan name is necessarily Libyan, nor does a Greek name imply a purely Greek origin of its bearer". 298

Herodotus (4.155) had learned that 'battus' meant 'king' in the Libyan language and suggests accordingly that this may have been a title imposed on Battus later in his life (that is, once he was king in Cyrene). ${ }^{299}$ However, he also reports that Battus' name could have been engendered from his supposed stammer, alluding to the verb $\beta \alpha \tau \tau \alpha \rho i ́ \zeta \varepsilon ı v$ meaning 'to stammer'. ${ }^{300}$ As Applebaum points out, the first option, that Battus gained his name through his role as king, is in accordance with other sources (Diodorus 8.29; Pindar Pythian 5.87; SEG 9.189) who state that Battus originally possessed the name Aristoteles. ${ }^{301}$

Another example of using onomastics to assess the relations between the Cyrenaeans and the Libyans is King Alazeir of Barca (another Greek colony in Libya). Due to his name, he was originally thought to be a Libyan, but Herodotus (4.164.4) states that his daughter was the wife of Arcesilaus III (reigning 530-515 BC) of Cyrene, to whom she was also related by blood, thus making her a member of the Battiad dynasty. This suggests that either Alazeir was a Libyan and his daughter's Battiad descent came from her mother; or that Alazeir was a Battiad

\footnotetext{
${ }^{296}$ Marshall (2004)130.

${ }^{297}$ Marshall (2004) 127-128.

${ }^{298}$ Laronde (1990) 178.

${ }^{299}$ White (1987) 79. Parke \& Wormell (1956) 74 use this point to argue that the oracle given to Battus must be anachronistic.

${ }^{300} L S J$ sv. $\beta \alpha \tau \tau \alpha \rho i ́ \zeta \omega$

${ }^{301}$ Applebaum (1979) 13. Malkin (1987) 63 however, draws to attention to the Greek tradition (still in practice today) of naming the first born son after their paternal grandfather - Battus' grandson was indeed Battus, so-called the Fortunate - which implies the use of 'Battus' was more of a name than a title.
} 
with a Libyan name. The latter suggests that intermarriage could have occurred in an earlier generation, hence the Libyan name. ${ }^{302}$

A second or first century BC list of 90 names found at el-Gubba, 44 kilometres east of Cyrene, gives us further insight into this issue. ${ }^{303}$ The names in the list, laid out in $S E G$ 9.348, are probably too many to correspond to a group of magistrates, and instead, Laronde suggests that they are related to the optimum size of a sedentary population that was able to live off the surrounding land. ${ }^{304}$ More central to our discussion, both the names and patronyms of individuals are given in this list. The result of an analysis of these names leaves us with only seven individuals of indigenous (Libyan) origin, 19 individuals of Cyrenaean (Greek) origin, and the remainder indistinguishable. ${ }^{305}$ Even with such a large number of the total names being indistinguishable, this list provides a number of insights. Firstly, it demonstrates that the community was indeed a mixed one. Certainly Cyrenaeans and Libyans were living side by side, and it would not take much imagination to suppose some intermarriage may have taken place. The origin of this list is important as it demonstrates that the Greek presence in Libya had dispersed significantly by the second century $\mathrm{BC}$, at least from Cyrene to el-Gubba, and consequently it is possible to postulate that interpenetration with the indigenous population took place. ${ }^{306}$

Despite all the evidence discussed above, it is difficult to draw any firm conclusions about intermarriage as a widespread practice at Cyrene's inception. The evidence discussed so far covers dates from at least 200 years after the Greek colonists first arrived. Although much of this presents intermarriage as likely, there are also indications in Herodotus that relations between the Greeks and Libyans may not have been as amicable as they appeared, discussed further below.

\footnotetext{
${ }^{302}$ Graham (1981-82) 296-297.

${ }^{303}$ Laronde (1990) 178-179.

${ }^{304}$ Laronde (1990) 179.

${ }^{305}$ Laronde (1990) 179.

${ }^{306}$ Laronde (1990) 179.
} 
Herodotus (4.159.2-4) decribes the influx of new settlers to Libya and states that the newcomers were invited to take part in the division of land: ${ }^{307}$

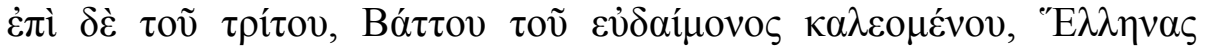

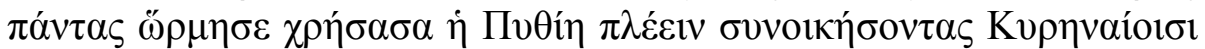

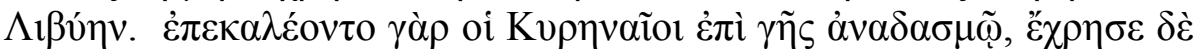

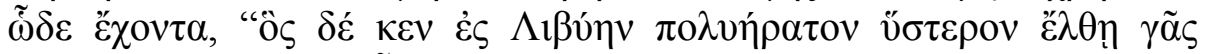

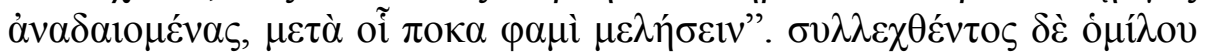

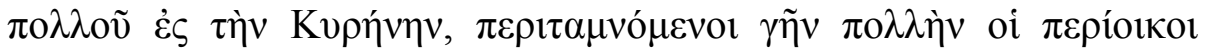
$\Lambda$ íßves.

In the time of the third ruler, known as Battus the Fortunate, the Pythia gave an oracle urging all the Greeks to sail [to Cyrene] so as to dwell with the Cyrenaeans in Libya. For the Cyrenaeans called them in to a land distribution. [The Pythia] proclaimed this: "whoever should go to much-loved Libya late [after the land had been distributed], I say to him that he will regret it forever". A great multitude gathered at Cyrene, cutting off much land from the neighbouring Libyans.

Herodotus goes on to describe how relations between the Cyrenaean Greeks and the Libyans began to break down, with the loss of the latter's land. The Libyans, resenting the loss of their territory appealed both to their king, Adicran, and the Egyptian king Apries. A battle at Irasa followed, and the Libyans and Egyptians were badly defeated by the Cyrenaeans. ${ }^{308}$ Such a breakdown of relations between the Cyrenaeans and Libyans could imply that intermarriage was less likely to occur at this time.

Cyrene appears to have had a rapid population growth following this. Herodotus (4.160) states that in the battle at Leucon, the Cyrenaeans lost as many as 7000 hoplites. While we must be wary of the accuracy of Herodotus' figures, it is plausible that this could reflect a very large population expansion in the reign of Battus II and the early stages of the reign of his son, Arcesilaus II. ${ }^{309}$ Possibly this could be due to intermarriage, although for such a dramatic increase in such a short period of time, a considerable number of Cyrenaean Greek men would have married Libyan women near the start of Battus II's twenty-odd year reign, so that

\footnotetext{
${ }^{307}$ Compare this to Thasos, where Archilochus (F 102 West) described how 'the scum of all Greece flocked to Thasos' so that they might compete against the Thracian tribes for the gold mines on the island. Herodotus (6.46-47) and Thucydides (1.100.2) attest to the affluence of these mines. See Van Wees (2004) 29, 261. These are examples of so-called 'proto-colonists' joining an already established colony.

${ }^{308}$ Stucchi (1989) 75; Mitchell (2000) 86. Mitchell dates this battle to shortly before 570 BC. As a result of the defeat, Apries lost his throne to Amasis, who became pharaoh in $570 \mathrm{BC}$. Herodotus (2.161-163) tells this story in his account of Egypt.

${ }^{309}$ Mitchell (2000) 87.
} 
the offspring of these unions could be old enough to fight as hoplites in the Battle at Leucon. ${ }^{310}$ This does seem plausible. Another way in which the population of Cyrene could have dramatically increased is by the inclusion of Libyans (males) within their own population count. This seems unlikely due to the breakdown of relations between the two peoples during the reign of Battus II, leading to the Battle at Irasa.

A further shipment of Greeks from the mainland during the reign of Battus II may have augmented Cyrene's population. The influx of mainland Greeks certainly was considerable enough to make an impact on the surrounding Libyans who were displaced from their land. Thus, it seems reasonable to suppose that these new colonists could have significantly boosted the Cyrenaean population, to the extent that they had 7000 hoplites who died at Leucon. In particular, an even greater number of mainland Greeks could have been absorbed into the population if they had settled into the wider territory surrounding Cyrene, not just the city itself. The fact that the Greeks were invited to share in land distribution and that the oracle proclaimed that settlers should go to Libya (rather than Cyrene), could suggest that the Greeks were not merely contained within the city, Cyrene. It would appear that the influx of Greek colonists could have boosted the population significantly. Of course, it is more likely that the population expansion was the result of a combination of some intermarriage together with a large number of settlers from Greece.

At first glance, the evidence suggests that intermarriage between colonists and the indigenous women took place at Cyrene - the possibility that it was men alone who went on the initial colonising venture, the impacts of each society on the customs and practices of the other, the literary evidence, and the edict of Ptolemy I which may have been an attempt to regularise existing practice. All these points argue in favour of intermarriage. To counter that, the sudden increase in the number of colonists during the reign of Battus II and the subsequent breakdown in relationship between the two groups points, at the least, to a less favourable time

\footnotetext{
${ }^{310}$ Intermarriage to produce 'citizen' offspring could only be between Cyrenaean Greek men and Libyan women; unions between Cyrenaean women and Libyan men would not be acknowledged as marriages. See Mitchell (2000) 99.
} 
for intermarriage to occur. On balance, however, and over time, intermarriage does seem rather more likely than not.

\title{
Western Mediterranean
}

\begin{abstract}
Massalia
Massalia, modern day Marseilles, is located in France. Both Thucydides (1.13) and Strabo (4.1.4) tell us that Massalia was founded by the Phocaeans. It appears to have been settled c. $600 \mathrm{BC}$, around the same time as Emporion (in Spain, discussed briefly in Chapter One). ${ }^{311}$ Massalia would later become one of the most important centres for trade and was the largest city in the Western Mediterranean (indigenous or Greek) until after the Roman conquest. ${ }^{312}$
\end{abstract}

The literary evidence offers a clear example of intermarriage between the Greeks and the indigenous population. Athenaeus (13.576a-b), quoting from Aristotle's (now lost) Constitution of the Massaliotes, records the intermarriage between the indigenous king's daughter and the Greek leader:

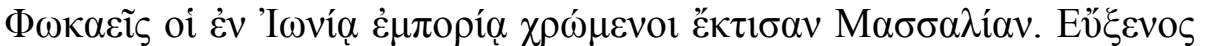

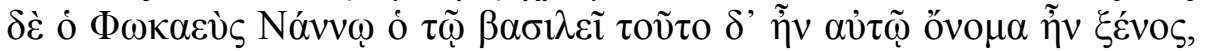

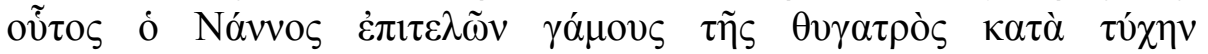

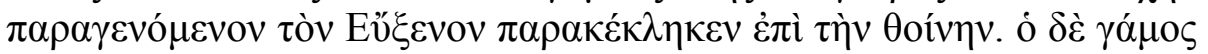

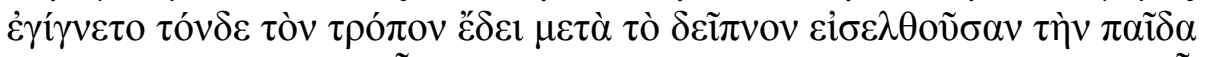

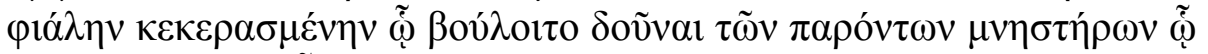

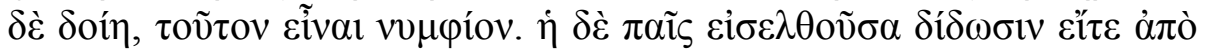

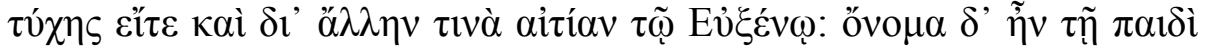

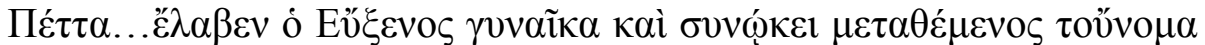

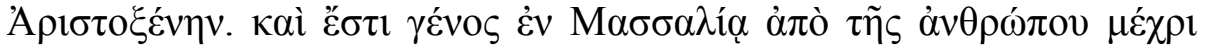

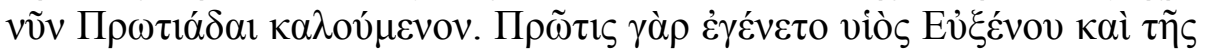

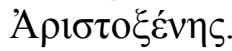

The Phocaeans of Ionia were traders and founded Massalia. Euxenus of Phocaea was a guest-friend of King Nannus, which was actually his name. Nannus was celebrating his daughter's wedding, and since Euxenus happened to be there, he invited him to the feast. The wedding was organised in this way: after the meal, going in, the girl was to give mixed wine to whichever suitor there she might want, and whoever she gave it to would be her bridegroom. Having entered the

\footnotetext{
311 Whitley (2001) 125 describes Massalia as the 'last major Greek colony'. This description assumes that the Greek colonies of the Black Sea were almost part of a different 'movement'; a view that is not subscribed to in this thesis. There is also debate over whether Massalia and Emporion were founded concurrently, or whether Massalia was founded first, before the colonists moved south to Emporion. See Mierse (1994) 790-794.

${ }^{312}$ Dietler \& Lopez-Ruiz (2009) 10.
} 
room, either by chance, or by some other reason, the girl gave it to Euxenus: her name was Petta... Euxenus married the girl and set up dwelling, changing her name to Aristoxene. And there is a family in Massalia now descended from her, called the Protidae, for Protis was the son of Euxenus and Aristoxene.

In this tradition, it is apparent that the Greek oikistes was a guest-friend of the indigenous leader. This suggests that firstly, the area had been previously explored prior to Massalia's establishment; and secondly, that the relationship between the oikistes and the indigenous king was a very friendly one, so much so that land was given to him to settle in the area that came to be known as Massalia. Archaeological exploration has not revealed any evidence of prior settlement on the site, so it appears that the land given to the Greeks was virgin. ${ }^{313}$ This is comparable to the founding of Megara Hyblaea in Sicily, discussed above.

Similarly, summarising Pompeius Trogus, Justin (43.3.8-11) reports:

Duces classis Simos et Protis fuere. Itaque regem Segobrigiorum, Nannum nomine, in cuius finibus urbem condere gestiebant, amicitiam petentes conveniunt. Forte eo die rex occupatus in apparatu nuptiarum Gyptis filiae erat, quam more gentis electo inter epulas genero nuptum tradere illic parabat. Itaque cum ad nuptias invitati omnes proci essent, rogantur etiam Graeci hospites ad convivium. Introducta deinde virgo cum iuberetur a patre aquam porrigere ei, quem virum eligeret, tunc omissis omnibus ad Graecos conversa aquam Proti porrigit, qui factus ex hospite gener locum condendae urbis a socero accepit.

The leaders of the fleet were Simos and Protis. And so they met the king of the Segobrigi, whose name was Nannus, in whose territory they were eager to found a city, seeking friendship. By chance that day, the king was busy with preparation for the wedding of his daughter Gyptis, whom by the custom of his race he was prepared to give as bride to one chosen from among the banquet guests as a son in law. And thus, since all the suitors invited to the wedding were there, the Greeks were asked as guests to the feast. Then, the girl was led in and commanded by her father to pass the water to whomever of the men she chose. When she ignored everyone and went over to the Greeks, she passed the water to Protis, who, having gone from stranger to son-in-law, received a place from his father-in-law for his city to be founded. ${ }^{314}$

\footnotetext{
${ }^{313}$ Shefton (1994) 61.

${ }^{314}$ Little is known about Justin, other than that he was an historian who lived under the Roman Empire. His exact dates are uncertain. Nevertheless, even the beginning of the Roman Empire is considerably after the foundation of Massalia and so our analysis must take into consideration his lateness as a source.
} 
This passage has clear parallels with Athenaeus. While the names differ (with Euxenus now called Protis, and Petta called Gyptis), the basic events are the same. ${ }^{315}$ It is interesting to note that the marriage between Protis and Gyptis does not appear to be forced; that is, she was not physically seized by him (compare, for example, the Sabine women). ${ }^{316}$ In the evidence it appears that Gyptis picked her own husband. Furthermore, Justin clearly reports that all the colonists were invited, and so cannot be considered unwelcome. Lyons has interpreted this marriage as a symbolic transmission of power, legitimising the Phocaeans' claim to land surrounding their new settlement. ${ }^{317}$

In direct contrast to this literary evidence indicating that intermarriage took place right from the start of the foundation of Massalia, we are also told by Strabo (4.1.4) that at least one woman was indeed taken from the homeland to the new settlement.

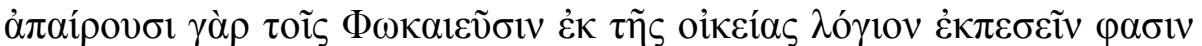

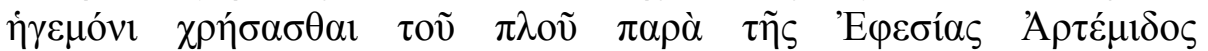

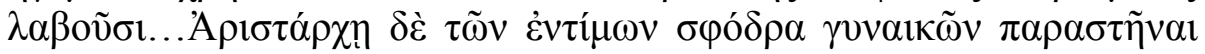

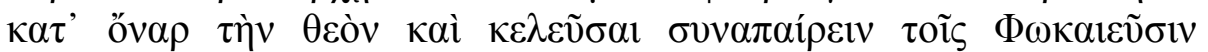

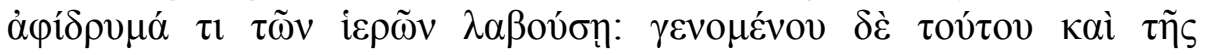

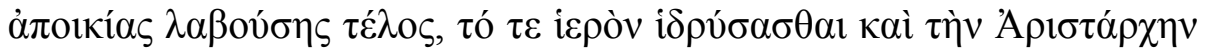

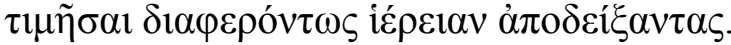

For, they say that when they were leaving their home, [the Pythia?] sent an oracle to the Phocaeans commanding them to take from Artemis of Ephesus a leader for the expedition... the goddess appeared in a dream to Aristarcha, [one] of the most honourable women, and told her to sail away with the Phocaeans, taking an image of the holy things: when these things had happened and the colony was founded, they set up the temple and honoured Aristarcha, appointing her priestess above all.

This passage from Strabo clearly reveals that Aristarcha travelled with the colonists to Massalia. However, Aristarcha is described as being 'of the most honourable women' thus distinguishing her from other women, most probably by her status and influence. ${ }^{318}$ Graham points out her exceptional position is emphasised by the fact that her name has been preserved in the record; other than

\footnotetext{
${ }^{315}$ Morel (2006) 365 accepts that even with the limitations of these sources, the stories probably contain a 'core of plausibility'.

${ }^{316}$ As such, this has led Lyons (2000) 89 to describe the union as 'legitimate intermarriage'. I, however, am not making a point of distinguishing between forced intermarriage and willing.

${ }^{317}$ Lyons (2000) 89.

${ }^{318}$ Van Compernolle (1983) 1040.
} 
the names of the oikistai, it is rare for names to have been recorded. ${ }^{319}$ It also appears that Aristarcha was notable in this tale for being the only woman who accompanied the colonists on the voyage. Indeed, Shepherd argues that these records of the activities of such females neither preclude nor include similar participation by other women. ${ }^{320}$ Either way, however, the actions of one woman (especially those of a priestess) cannot be extrapolated to all females.

Graham argues that priestesses would always have been transported to the new colonies: "all Greek colonies would need Greek women in order to ensure a proper relation between the community and its gods, and it's absurd to imagine that native women, who did not even speak Greek, could be entrusted with these important tasks." 321 In addition to Massalia, there is evidence that at Thasos a priestess named Kleoboia was also transported to the new colony. Pausanias (10.28.3) describes a painting at Delphi by Polygnotus, depicting the girl in Charon's boat holding a chest associated with Demeter on her lap, bolstering the opinion that Kleoboia was the first to bring the rites of Demeter from Paros to Thasos. Graham argues that it was common for females to serve female deities, and males to serve male deities (with exceptions, of course), hence the importance of having Greek women in the colonies. ${ }^{322}$ That said, however, it does not mean that every single woman in a colony would need to be Greek - rather, one Greek priestess could be transported when required for religious purposes, and indigenous women used for marriage, reproductive, or other purposes. Further, this line of argument does not consider the potential for syncretic religions, which would not necessarily require Greek women in the capacity Graham suggests.

The literary evidence relating to Massalia thus leaves us with a dichotomy. There is evidence in favour of intermarriage (Justin and Aristotle), and evidence revealing that women, or rather, at least one woman, was transported with the colonists to the new settlement (Strabo). Dominguez suggests that the stories contained in Justin and Aristotle reflect the initial arrival of the Phocaeans in Massalia, whereas Strabo's account relates to the later arrival of more Greeks once the new settlement had become more established (likely Phocaeans, following the

\footnotetext{
${ }^{319}$ Graham (1981-82) 302-303.

${ }^{320}$ Shepherd (2012) 220; Shepherd (1999) 270.

${ }^{321}$ Graham (1995) 13; see also Schaps (1979) 73 for the importance of women in Greek religion.

${ }^{322}$ Graham (1981-82) 304.
} 
Persian conquest of their city; compare to Herodotus 1.164). ${ }^{323}$ On the other hand,

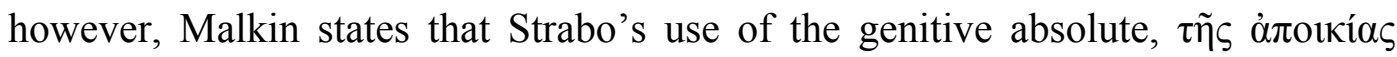
$\lambda \alpha \beta o v ́ \sigma \eta \varsigma \tau \varepsilon \dot{\lambda} \mathrm{o}_{\mathrm{s}}$, is more indicative of the original foundation. ${ }^{324}$ It has also been argued that the Aristarcha of this tale was a later invention to account for the presence of the Temple of Artemis of Ephesis at Massalia, and the consequent transference of cult. ${ }^{325}$ It is perhaps most significant that she was to serve a specific role in the new colony, as a priestess. Many Greek priestesses were virgins, and as such, we could conjecture that Aristarcha was to remain a virgin, and cannot consequently be considered as a 'Greek wife' or a woman who could later become a wife, relevant to the question at the heart of this thesis.

The archaeological exploration of Massalia has been hampered by modern settlement. However, Shefton reports that archaeological investigation has demonstrated that prior to the Greeks' arrival, the site was uninhabited (though there is evidence of an earlier Etruscan presence in the area dating to around the mid-seventh century BC). ${ }^{326}$ Archaeologically, it also appears that the Greek colonists and the indigenous population were fairly integrated. Morel reports that local or indigenous pottery accounts for about $30 \%$ of the pottery thus far uncovered. ${ }^{327}$ This mix, according to Tsetskhladze, is due to the small chora of Massalia which encouraged close relations to ensure prosperity and survival of the colony. ${ }^{328}$ For Massalia, then, the main evidence is literary and this evidence suggests intermarriage, but that at least one woman, a priestess, accompanied the colonists. The weight of this evidence, however, reinforced by archaeological finds, leans in favour of intermarriage.

\footnotetext{
${ }^{323}$ Dominguez (1999) 77. Hodos (1999) 66 has suggested that priestesses joining protocolonists (that is, the second wave of colonists following the establishment of the settlement) was more common than just this instance.

${ }^{324}$ Malkin (1987) 70.

325 Rouge (1970) 312; Shepherd (1999) 270. See also Van Compernolle (1983) 1040. The connection between Massalia and the cult of Artemis of Ephesos is noted again by Strabo (4.1.4).

${ }^{326}$ Shefton (1994) 61.

${ }^{327}$ Morel (2006) 366.

${ }^{328}$ Tsetskhladze (2006c) lxv.
} 


\section{Black Sea}

Greek colonisation of the Black Sea region was highly prolific and its inclusion in an examination of archaic Greek colonisation should be imperative. Yet, the Black Sea is also one of the most problematic areas of the Greek world to study. Until very recently geographical, social, and political factors have prevented extensive study of the Black Sea. The Soviet Union closely controlled its territory which precluded many opportunities for excavation particularly by western scholars. ${ }^{329}$ Some limited excavation was carried out by eastern scholars, though this was performed without the 'classics lens' that one would usually expect of excavations of classical sites. ${ }^{330}$ In addition, there is little analysis of the archaeological evidence which makes interpretation challenging. Furthermore, there was (and to a certain extent, still is) a very limited crossover of scholarship between eastern and western scholars, and any crossover is made more challenging by language barriers. ${ }^{331}$ Many western scholars do not read Russian, Ukranian, or Georgian (for example), and so there are few who are able to move seamlessly between the eastern and western scholarship. Language differences and an apparently different (cultural) mentality make the countries surrounding the Black Sea seem even further away for western scholars. They have been described by Heinen as 'a different world', leading to a tendency for many western scholars to ignore the Black Sea region altogether. ${ }^{332}$ Others tend to juxtapose it against the colonisation which took place in the west, as if it were a completely different process. ${ }^{333}$

To complicate matters further, there are also archaeological difficulties in studying the Black Sea area, even now that it has been opened up for study. On the Bulgarian and Romanian coasts, all the Greek cities (with the exception of Histria)

\footnotetext{
${ }^{329}$ Heinen (2001) 3.

330 Tsetskhladze (1994) 112. The eastern scholars had no, or very limited, access to western scholarship until the dissolution of the Soviet Union in 1991.

331 Graham (1961) 194. Scholars are beginning to make more of an attempt to combine their western and eastern efforts; this is particularly visible in the Colloquia Pontica series used in this thesis: Tuplin (ed) (2003); Tsetskhladze (ed) (2001); Solovyov (1999); and the work conducted by the Danish National Research Foundation's Centre for Black Sea Studies: see http://www.pontos.dk/.

${ }^{332}$ Heinen (2001) 3.

${ }^{333}$ Petropoulos (2005) 6.
} 
lie under modern cities making extensive excavation near impossible. ${ }^{334}$ On the Colchian (modern-day Georgian) coast, the Greek cities are yet to even be located archaeologically. In addition, many of the excavations that have been completed have never been published (for example, many of the results from Berezan). ${ }^{335}$

The area covered by the Black Sea itself has also fluctuated considerably over time. ${ }^{336}$ For example, at Olbia on the northern coast, the modern coastline is 400 500 metres back from the ancient one, meaning parts of the ancient settlement are underwater. $^{337}$ Multiple other settlements are also now submerged and require underwater exploration and excavation. ${ }^{338}$ This makes archaeological exploration more difficult, especially in instances where settlements (or parts of settlements) have fallen away into the water, effectively destroying the opportunity to study them in situ. ${ }^{339}$

The reasons for the archaic colonisation of the Black Sea area are not immediately obvious. Unlike the majority of other colonies discussed in this thesis, there are virtually no literary sources for the Black Sea that might proffer evidence to better assess this issue. Herodotus has a limited focus in his description of Scythia, aiming to familiarise his audience with the physical area, rather than the Greek colonies or indigenous peoples (see, for example, 4.85-86 on the physical dimensions of the Black Sea, Bosporus, and Hellespont). ${ }^{340}$ Other authors, too, make passing references, such as Polybius' (4.56) description of the city Sinope on

\footnotetext{
${ }^{334}$ Tsetskhladze (1998b) 18.

335 Petropoulos (2005) 3.

${ }^{336}$ Shilik (1997) 115: "the global eustatic transgression resulted in a considerable rise in sea-level during Late Quaternary period by no less than 110-120 m over the past $20 \mathrm{ka}$, from the Last Glacial Maximum to the present day. Minor oscillations are distinguishable against the background of this general trend, their frequency being 1500/2000 years and their amplitude exceeding $10 \mathrm{~m}$." Such oscillations are clearly visible in the Black Sea.

${ }^{337}$ Tsetskhaladze (1998b) 19.

${ }^{338}$ Some limited underwater exploration has been conducted; for example Lapin in 1961 led a team from Moscow in underwater excavation of Berezan. However, Nazarov (1997) 133 reveals that it was limited by insufficient equipment and experience, coupled with poor visibility, leaving the team to primarily establish sea depth and sediment thickness. Some further exploration has been conducted since but the results of this are limited to those who have an understanding of Cyrillic languages.

339 For example, at Berezan, some archaeological deposits are visible in the sides of the sea cliff, and other finds have been made by local fisherman off the coast. See Nazarov (1997).

${ }^{340}$ Petropoulos (2005) 1. Herodotus' discussion on the Black Sea has been questioned, in terms of whether he claimed he went there, and whether he did in reality. Armayor (1978) 62 argues that "if Herodotus went to the Black Sea at all, his narrative bears little or no relation to whatever his travels may have been...Herodotus drew heavily on previous Greek traditions of the north when he came to build these claims". See also West (2007).
} 
the southern coast. Unfortunately, none of these various pieces of literary evidence look at Greek colonies or colonisation directly, or even indirectly.

Roebuck argued in 1959 that the main reason behind Greek colonisation in the Black Sea area was an interest in metal particularly in the south and east, ${ }^{341}$ and an interest in the grain of the north. ${ }^{342}$ This argument was held to be true for many years, until a study by Tsetskhladze and Treister in 1995 established that the area surrounding the Black Sea was not in fact rich in metals, and crucially, that the Milesians (who instigated several colonies in the region) had access to various natural resources much closer to home. ${ }^{343}$ The presumed interest in grain has also been discounted. Pashkevich demonstrated that the Greek colonists did not plant crops that were indigenous to the Black Sea but instead brought familiar crops with them from the mainland. ${ }^{344}$ Furthermore, it is unlikely that any large exports of grain were made until a much later period, as the total population of the various Greek colonies must have been very small. ${ }^{345}$ Therefore, it seems unlikely that the push to colonise the Black Sea region was due to the desire to exploit resources.

We know that the situation in the homeland was often the impetus for colonisation. Megara, for example, suffered the loss of some land to their dominating neighbours, the Corinthians and Athenians, in the seventh and sixth centuries BC. ${ }^{346}$ It is possible that the main driving force for the Megarians to colonise was to satisfy their land hunger and replace lost land, most notably by settling at Heraclea Pontica. Without more detailed literary evidence, however, it is near impossible to become more certain of the reasons behind the colonisation of the Black Sea.

It is also difficult to assess the relationship between the Greek colonists and the indigenous populations. Petropoulos notes that modern Scythian specialists argue against the existence of a permanent (settled) indigenous population along the northern coast of the Black Sea. ${ }^{347}$ Herodotus (4.127.1-2) addresses this issue,

\footnotetext{
${ }^{341}$ Roebuck (1959) 87-103.

${ }^{342}$ Roebuck (1959) 116-130.

${ }^{343}$ Tsetskhladze \& Treister (1995); Tsetskhladze (1995); Tsetskhladze (2006c) xxix.

${ }^{344}$ Pashkevich (2001).

345 Petropoulos (2005) 58. Petropoulos suggests that there may have only been six or seven permanent settlements throughout the entire Black Sea until c. 580 BC.

${ }^{346}$ Hind (1998) 131-133.

${ }^{347}$ Petropoulos (2005) 26.
} 
citing a message from Idanthyrsus, the Scythian king, given to the Persian king Darius:

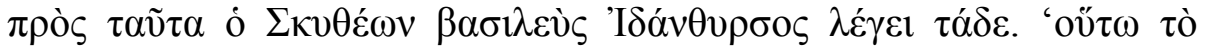

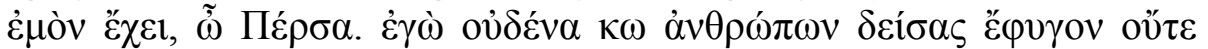

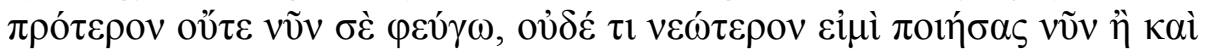

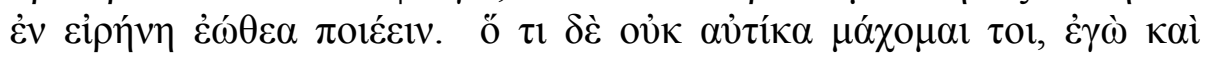

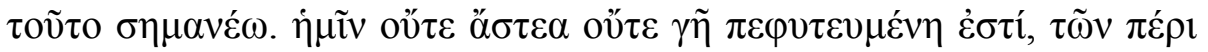

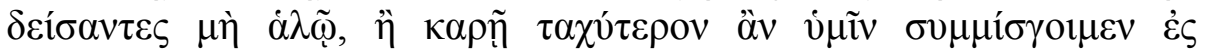
$\mu \alpha ́ \chi \eta \nu \ldots$

To this the Scythian king, Idanthyrsus replied: 'Persian, this is my practice. I have never yet fled from any man in fear, not before, nor do I flee from you now. I am not doing anything now other than I am accustomed to. As to why I don't fight you forthwith, I will tell you. We have neither towns, nor cultivated land, [so that] fear of losing it or [seeing it] ravaged, might bring us together to hasty battle.'

Herodotus notes that the Scythians (and indeed the Thracians and Getae too) were essentially a nomadic people; seemingly even more so than those of Libya. ${ }^{348}$ They did not appear to form any sort of homogenous ethnic group. ${ }^{349}$ Herodotus (4.81.1) himself seems confused about their numbers, and even about who counted as a Scythian and who did not:

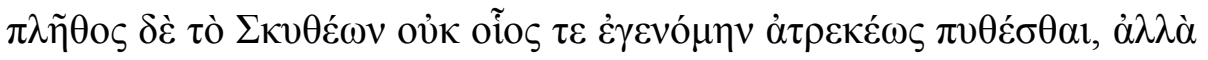

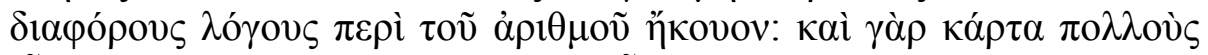

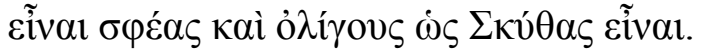

I was not able to learn exactly how numerous the Scythians are, but I heard different accounts about their numbers: for [some say] they are very numerous, and [some say] they are few, as Scythians.

The interpretation of the Scythians as nomads is not straightforward. Petropoulos suggests it is likely that the Greeks brought wives with them to this area, given that the contact between the settling Greek colonists and the roaming nomads was presumably minimal. ${ }^{350}$ This is an attractive proposal, although we cannot be sure of the degree of contact one way or another.

\footnotetext{
${ }^{348}$ See also Herodotus (4.2.2) where in reference to the Scythian treatment of their slaves and

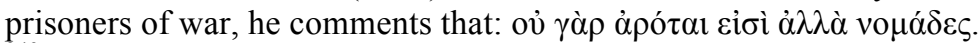

${ }^{349}$ See Herodotus $(4.17-27$; 99-117) for some distinctions.

${ }^{350}$ Petropoulos (2005) 124.
} 
One of the best excavated areas in the Black Sea region includes Olbia and modern day Berezan, both located in the north. ${ }^{351}$ Berezan is thought to be the Milesian colony, Borysthenes, and is often described as the oldest colony in the northern Black Sea. ${ }^{352}$ Both settlements are notable for a number of 'dugout' buildings (Figure 11). These were each 100-262 square metres and appear to have contained a number of domestic areas (both work and living) all centred around an interior courtyard. ${ }^{353}$ Previously these have been interpreted as temporary living structures for the new colonists. ${ }^{354}$ However, Solovyov has postulated that it is unlikely that every single one of these structures was used by the colonists, given their relatively great number; instead, he believes that only two or three were occupied by the Greeks. ${ }^{355}$ This is hard to reconcile with the notion conveyed in the literary evidence that the indigenous peoples of this area were nomads. ${ }^{356}$ However, it is possible that the area and its inhabitants were sufficiently unknown to the Greeks (at least in so far as they convey to us in the extant literary evidence, for example Herodotus 4.81.1 discussed above), and plausible that the indigenous population

\footnotetext{
${ }^{351}$ Excavations were begun at the end of the nineteenth century; however, these have been halted a number of times for political reasons, and many of the results have never been published (see in particular, Solovyov (1999) 19-27; also Petropoulos (2005) 3; Solovyov (2001) 118). Most recently, see Petersen (2010) 41-120 for a succinct summary of all the excavation of Olbia, particularly of the cemetery, though much of this material is too late for the purposes of this thesis. Petersen (2010) 115 also points out that the majority of Berezan's excavation reports remain unpublished, and now have been separated from the actual burial finds.

${ }^{352}$ Solovyov (2001) 117. There is, however, some debate as to the ancient name of this settlement. Solovyov (1998) 205, for example, uses the name Borysthenes interchangeably for both Berezan and Olbia. Berezan is now an island, but it is thought that it was a peninsula in antiquity (see Boardman (1998) 201; Kryzhitskii (1997) 101; Hind (1983-1984) 79), with Olbia opposite. There is also confusion over the order in which Berezan and Olbia were settled; that is, whether Berezan was settled first, and then colonists moved to Olbia, or whether the two settlements were established concurrently. The archaeological evidence does not particularly help solve this issue. Boardman (1998) 202 has suggested that the foundation dates were close which would explain why the two cannot be distinguished archaeologically. Graham (1982) 125 argues that Olbia and Berezan were settled concurrently, however his (1994/2001) publication acknowledges that his argument has been universally rejected by Russian scholars.

353 Solovyov (2001) 129. These buildings were probably single storey, but as Solovyov points out, it is not possible to exclude the presence of a second storey.

${ }^{354}$ See especially Kuznetsov's (1999) chapter which asseses this issue; also Tsetskhladze (1998b) 20, 44; Kryzhitskii (2007) 19;

${ }^{355}$ Solovyov (2001) 126-128; 131 . This view is also formed by later changes taking place in the third quarter of the sixth century BC when many of the dugouts were filled in, having been recently surrendered by their occupants. This occurred concurrently with other changes to the cultural face of Berezan. This 'urbanisation', Solovyov believes, can only have taken place as a result of mass immigration and the organisation of the organs of government. Kryzhitskii (2006) 108 states that these dugouts cannot be used as indicators of ethnicity given their status as "structures of a transient character".

${ }^{356}$ Buyskikh (2007) 24-26 considers Solovyov's above revision of the scholarship to be "absurd", and argues that Solovyov used an unreliable methodology and ignored the broader picture where such dugouts had been found in other early Greek settlements in the wider region.
} 
was not a homogenous group, so that some were nomads and others were not. If we are to agree with Solovyov's interpretation of the dugouts, it seems that there was certainly some interaction between the indigenous peoples living in the dugouts and the Greek colonists. ${ }^{357}$ Furthermore, Petropoulos reports that some indigenous handmade pottery, dating from the second half of the sixth century $\mathrm{BC}$, was found adjacent to Greek pottery. This could suggest that indigenous Scythians were living alongside the Greek colonists. The interpretation of the dugouts, in particular, can only be tentative, as like the fibulae, they are poor indicators of ethnicity.

Petropoulos postulates that given the relatively early period of contact, it is possible to assume that the relations between the Greek colonists and the various indigenous peoples were friendly, or at least not actively hostile. ${ }^{358}$ The traces of fire found at some Greek settlements in the Black Sea, dating to the beginning of the fifth century $\mathrm{BC}$, are thought to indicate the breakdown of relations between the indigenous population and the Greek settlers. ${ }^{359}$

Lack of literary evidence and limited access to eastern scholarship relating to archaeological discoveries mean that it is very difficult to reach an informed view about the nature of the relationsip between the Greek colonists and the indigenous populations in the Black Sea, and so even harder to assess the likelihood that intermarriage would have occurred. Clearly, the colonies of this region present a rich resource for further study, not only of the relationship between Greek settlers and the indigenous peoples, but of the region more generally as an important centre of the ancient world in its own right.

\footnotetext{
${ }^{357}$ Buyskikh (2007) 27 admits that the potential coexistence of Greeks and non-Greeks is still a controversial view that eastern scholars are reluctant to subscribe to.

${ }_{358}$ Petropoulos (2005) 27.

${ }^{359}$ Petropoulos (2005) 28.
} 


\section{CONCLUSION}

The picture of Greek colonisation that we can achieve will, therefore, always be drawn in rather broad lines, and the task of the historian is continually to try to improve the quality and validity of these rather general constructions. ${ }^{360}$ - A. J. Graham

This statement, made by Graham in 1971, demonstrates strikingly clear perception of the issues for the time it was made. It remains a fitting explanation of the struggles surrounding the study of Greek colonisation and an accurate description of the role that scholars must play in order to further scholarship and understanding. Consequently, in this conclusion I will focus on drawing together some common threads from my consideration of the relationship between Greeks and indigenous peoples in general, and in relation to the individual colonies discussed in the previous chapter. It is crucial to note, however, that each colony must continue to be assessed on its own merits; for the differences between each colony, each region, each mother city, and so on, are endless, ruling out any idea that the 'Greek colonies' can be considered a coherent and uniform phenomenon.

The tendency for new colonists to first settle on an island or another easily defensible place before relocating to their final settlement was common among the colonies discussed in this survey. This was observed definitely at Syracuse with Ortygia as the preliminary settlement; at Cyrene with the island Platea prior; and at Taras with Satyrion. Arguments have also been made that Pithekoussai was an island settlement before colonists moved to the Italian mainland to settle at Cumae. ${ }^{361}$ The situation with Borysthenes (or the island Berezan) and Olbia in the Black Sea is less clear, although some scholars have argued in favour of this process there too. ${ }^{362}$

We may only speculate about the reasons for these actions. It seems likely that these colonists first chose to settle on an island (with the exception of Satyrion/Taras) because islands are inherently easily defensible places. Logically,

\footnotetext{
${ }^{360}$ Graham (1971) 36.

${ }^{361}$ See footnote 138 above.

${ }^{362}$ Domanskij \& Marcenko (2003).
} 
it seems likely that this was a good opportunity to assess the surrounding territory, and locate and assess an appropriate place for permanent settlement. Importantly, it could also provide a suitable means to establish relations with the indigenous population inhabiting the area. Perhaps it also enabled a first occasion to intermarry. This may have involved forcing the indigenous population from its territory, or establishing some sort of friendly relationship conducive to coexistence. The process often appears obscure. In the case of Ortygia/Syracuse, the indigenous population was driven out of its lands (Thucydides 6.3.2), whereas at Platea/Cyrene, the indigenous population helped the Theraean colonists find the location of their final settlement (Herodotus 4.158). Both colonies began life on an island but their subsequent histories differed dramatically. Accordingly, it is very difficult to reach any general conclusion about any impact that settling on an island prior to the mainland could have had on the likelihood of intermarriage taking place.

Instead, the process of initially settling an easily defensible place before establishing the colony proper seems to speak more to the type of venture that the colonists were undertaking. Often such island settlements provided reconnaisance. The Greeks made their first moves toward settlement understanding that some sort of military action might be necessary. If so, can we assume that women would be less likely to accompany these expeditions and therefore that Greek wives (or more generally, Greek women) did not accompany the men on the journey? ${ }^{363}$ For example, at Syracuse (although the evidence is not entirely clear), it appears that the relationship between the Corinthian colonists and the indigenous population was considerably more hostile leading to the expulsion of the indigenous population and/or their subsequent subjugation by the newcomers. Obviously there are many limitations to this hypothesis. Is it really possible that the colonists knew whether their venture would involve military action prior to leaving their mother city? This would require a great deal of knowledge about their new destination. Some prior knowledge was not an unreasonable expectation, particularly with the colonies that appear to have been founded with the intention of utilising natural resources nearby or those established for trade purposes. On

${ }^{363}$ Diodorus Siculus (20.41.1), writing about the Hellenistic period, associates the presence of women and children in an army as being like a colonising expedition, and their absence as a sign of a military campaign. This is not necessarily good evidence for the colonies of the archaic period. 
the other hand, however, some colonies such as Cyrene appear to have been founded with little or no prior knowledge of the new lands, or even of where exactly they were setting sail for.

Some colonies were settled on so-called 'virgin land' while others were established where there were already existing indigenous settlements. The precise reasons behind this difference may never be known (or indeed if there was a specific reason beyond convenience or exigency), but it is interesting to reflect on what impact these various actions may or may not have had on the indigenous populations and how they affected the Greek-indigenous relationship, and accordingly the likelihood of intermarriage.

When colonies were founded on virgin land, it is important to identify whether or not that land was given to the Greeks by the indigenous population. Pithekoussai is relatively obscure on this point. Megara Hyblaea, Massalia, and Cyrene, however, were each definitely settled on virgin land. In the case of Megara Hyblaea there is debate over exactly how the verb $\pi \rho 0 \delta i \delta \omega \mu$ used by Thucydides (6.4) to describe the Sicel king Hyblon's action should be translated. The various options have already been extensively discussed, but I interpret Hyblon's actions as completely willing on his part though with the acknowledgement that there may have been ulterior motives behind the gift alongside sheer generosity. Furthermore, it seems that the Greek colonists and the indigenous Sicels had a good relationship that probably involved intermarriage. Massalia, too, has fairly convincing literary evidence (Athenaeus 13.576a-b; Justin 43.3.5-11) which reports the marriage between the Greek oikistes and the indigenous king's daughter, and states that land was also given as a part of this arrangement. Finally, at Cyrene (the colony with the most compelling evidence in favour of intermarriage) the Theraean colonists were physically led to the site of their settlement by Libyan guides (Herodotus 4.158). Accordingly, it appears that in many cases where the Greek colonies were settled on virgin land, it was given to them by the indigenous population (or their leader). Furthermore, the gift of land to the Greeks seems to have encouraged a good relationship between the colonists and indigenous peoples and consequently led to intermarriage between the two. But can the opposite scenario also be said to be true? 
Morgantina, Metapontum, Syracuse, Taras, and Locri were all colonies founded on land already occupied by another population. Morgantina and Metapontum stand apart from the others due to the fact they do not seem to have ever had a 'formal foundation'. That is, while there is a definite record of the continued occupation of their respective sites, it is not clear when the various Greek groups first arrived. By contrast, the arrival of colonists in Syracuse, Taras, and Locri is explicit in the literary record. More importantly, at each of these colonies, the newly arriving colonists are said to have driven away or ejected the respective indigenous populations who had been living on the land. On the surface, at Taras and Locri in particular, there is some evidence pointing to the presence of Greek women (or in the case of Taras, a woman) at the foundation of the colony. This conflicts with the assumption previously raised that women were less likely to accompany men on ventures which involved military action. On the other hand, however, the evidence for both Taras and Locri seems to have its tradition rooted in myth and certainly in the case of Locri (Polybius 12.5.3-11) the tradition may have served a later political purpose. Furthermore, Taras is linked to the presence of only one woman at the foundation (Pausanias 10.5-8) - a woman of exceptional status being the oikistes' wife. Consequently, these examples can neither be used to argue in favour of many Greek women being present, nor to definitely rule out the possibility of intermarriage.

The passage of time has obscured much about the specifics of each colonial venture. With the exception of Cyrene, we are left to piece together small fragments of various traditions to try and develop a fuller picture. We lack names in the record other than the occasional reference to an oikistes. Curiously, of the few names that we do have, only two of these belong to women and both of these were priestesses - Aristarcha of Massalia recorded in Pausanias 10.28.3, discussed extensively in the previous chapter; and Kleoboia of Thasos recorded in Strabo 4.1.4. Above all, this points to an argument about the importance of women in religion, and more specifically, of Greek women in Greek religion. ${ }^{364}$

\footnotetext{
${ }^{364}$ Graham (1981-82) strongly follows this line of argument; that the Greek colonists must have taken Greek women with them otherwise there would have been cult roles left unfulfilled. Although a role for women in religion should not be discounted, I do not accept the argument as it stands (or, in its entirety), especially as the colonies were seen to have taken on characteristics (including religious ones) of their new environment.
} 
Many of the foundation tales which we use as evidence are almost certainly invented at a later date (that is, long after the colony's foundation), invented to give the 'mixed bag' of peoples a common and precise origin. ${ }^{365}$ The precise reason for creating the tales is seldom obvious but we must assume that such stories always had the potential to hold an ulterior motive or to have undergone transformation as they were passed down the generations. The literary evidence is thus perhaps more disappointing and limited than we might have initially imagined. For this reason, archaeological evidence has acquired new importance in the second half of the twentieth century. Continued excavation, and the application of modern analytical techniques will be important to strengthen our knowledge of the colonies, in conjuction with the various pieces of literary evidence. Much more study also needs to be undertaken of indigenous populations and their practices, so that we might better compare them with the Greeks in the colonies.

The pitfalls of a heavy reliance on archaeology, however, were revealed in Chapter Three. Excavations tend to largely centre on the necropoleis of settlements, due to the fact that domestic environments tend to be less well preserved and distinguishing female from male is even less clear. ${ }^{366}$ Within the necropoleis, the fibulae associated in particular with the Italic colonies of Pithekoussai, Syracuse, and Megara Hyblaea demonstrated the dangers associated with trying to use archaeology as an indicator of identity or ethnicity. Buchner's well-known and well-regarded hypothesis argued that the presence of Italic fibulae as opposed to the typical Greek straight pins indicated that the wearers were no longer wearing the traditional Greek Doric peplos and therefore that they were not Greek women. ${ }^{367}$ This argument is questionable even for the colony for which it was initially proposed, Pithekoussai, but becomes even more problematic in relation to the fibulae of other colonies. At both Syracuse and Megara Hyblaea fibulae do feature, but they appear less frequently than the traditional straight pins. Furthermore, they seem to have had less of a practical function than their straight

\footnotetext{
${ }^{365}$ Malkin (2002b) 196.

${ }^{366}$ Desborough (1976) 27-28. Within the oikos, Nevett (1994) 99 demonstrates that evidence of gender separation is very limited. Nevett (1999) 127-153 argues that the Greek house in Sicily was considerably less structured than those in the mainland, with most rooms being multifunctional, and as a result, there is little to differentiate archaeologically the separation between the male and female parts of the household.

${ }^{367}$ Buchner (1979) 135.
} 
counterparts which were often found in pairs in graves on the shoulders of the deceased indicating that they were buried wearing the pins. Buchner's hypothesis would lead to the conclusion that the women at Syracuse and Megara Hyblaea were in fact Greek, rather than indigenous. While the evidence at Syracuse is inconclusive, at Megara Hyblaea there is fairly convincing evidence that the relations between the colonists and the indigenous Sicels were friendly, and as such that intermarriage more than likely occurred, which is difficult to reconcile with Buchner's hypothesis.

The serpentine fibulae associated with males are also difficult to fit within Buchner's theory. No one appears to have suggested that these could have belonged to indigenous males, but how else are we to interpret them if we follow Buchner's hypothesis to its logical conclusion? The existence of serpentine fibulae emphasises how important it is not to use fibulae to determine ethnicity or identity. The presence of fibulae can be no more an argument in favour of intermarriage than the occurrence of straight pins is against it. Other than the evidence pointing to the manufacture of fibulae at Pithekoussai, there is little else to suggest that the fibulae could not have been sourced from elsewhere through trade. ${ }^{368}$ This appears to be more likely until we discover other metal depositories in Sicily and evidence of metal-working. This is not to say, however, that we should rule out the possibility that both Greeks and indigenous people could have lived in the same settlements concurrently, accounting for the presence of both fibulae and straight pins.

The unsuccessful attempt to use archaeology as an indicator of ethnicity is also apparent at Morgantina and Metapontum. At both these sites a plethora of Greek pottery has been uncovered along with considerable amounts of indigenous ware. On the one hand, this mixture of pottery could be an indicator of the indigenous peoples and Greeks living side by side. On the other hand, however, the presence of Greek pottery is not necessarily indicative of the presence of Greek people as such objects can be easily acquired in great numbers through trade. Without the

\footnotetext{
${ }^{368}$ Hodos (1999) 74: "intermarriage can be dismissed in favour of trade as an explanation of how the Greeks in Sicily obtained their fibulae". I do not wish to argue that trade and intermarriage mutually exclude each other, but I suggest that trade was certainly a factor in the presence of these fibulae being found at colonial sites.
} 
use of DNA testing, archaeology is therefore a poor indicator of ethnicity and identity.

While Osborne's (1998) call for the eradication of colonisation from history books seems drastic, his underlying point is cogent and ought to be taken seriously. Colonisation cannot continue to be considered a uniform phenomenon and neither can the settlement of archaic colonies be evaluated in a similar way to eighteenth and nineteenth century colonisation. In the same way that each colony has different foundation dates, different mother cities, different foundation stories, and is settled in different locations for different reasons, so perhaps too the source of women for each colony also differed. Given these differences and uncertainties, broad conclusions about intermarriage as a widespread practice are as risky as broad conclusions about women and men travelling together in a joint colonial enterprise of archaic Greece. 


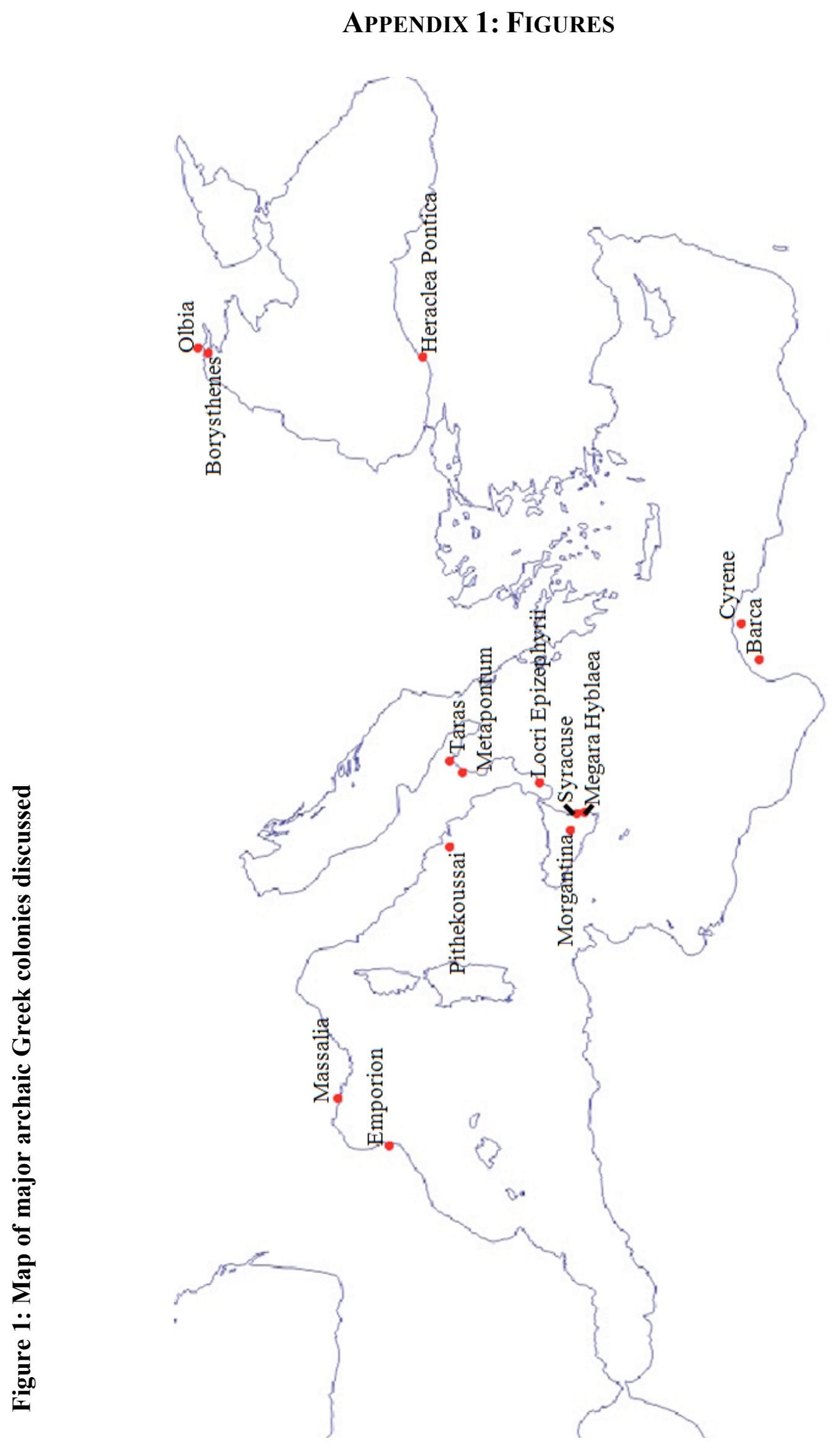

苛| 
Figure 2: Example of straight pin from Greece

Inv. No: 86.009, The University of Queensland Collection, c. seventh-sixth century BC, $10 \mathrm{~mm}$ diameter, $135 \mathrm{~mm}$ length.

Figure 3: Italic fibulae types - Nos 1-3: navicella fibulae; no 4: leech fibula; no 5: serpentine fibula; no 6: animal fibula; nos 7-8: bone and amber fibulae (drawings by Orsi 1895, based on fibulae from Syracuse)
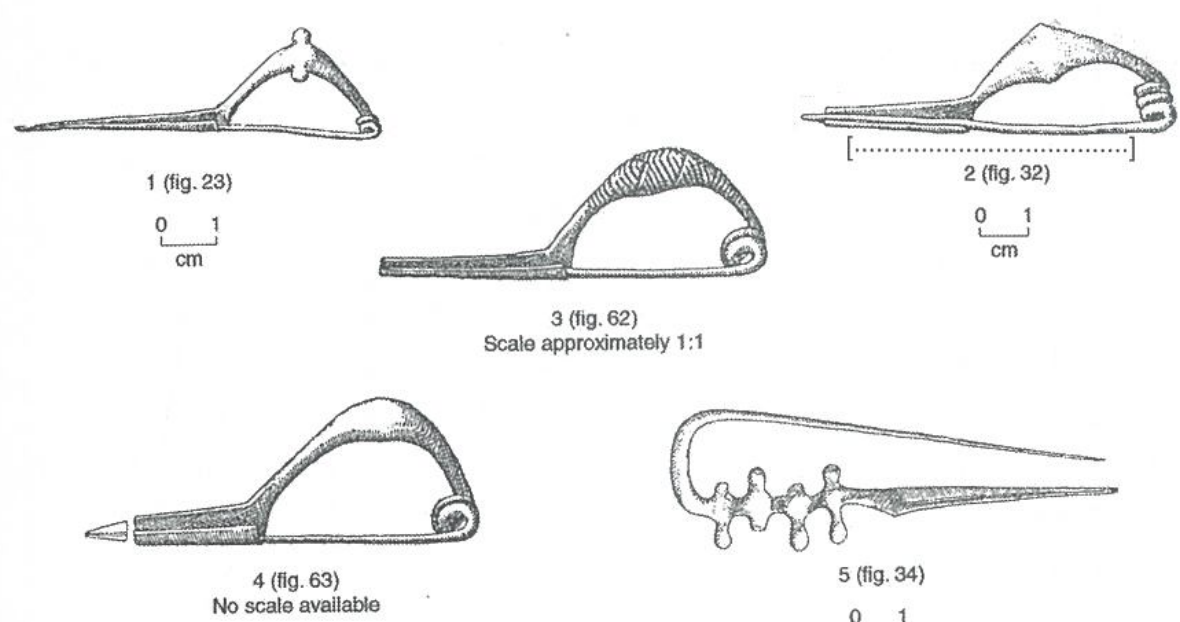

3 (fig. 62)

Scale approximately $1: 1$

No scale avaliable
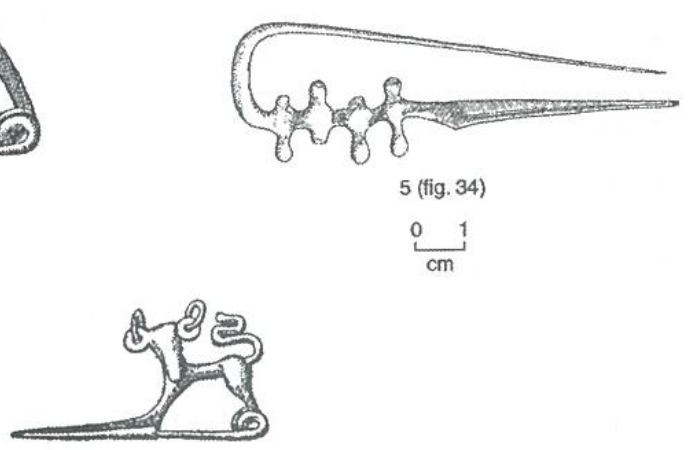

6 (fig. 73)

No scale avallable

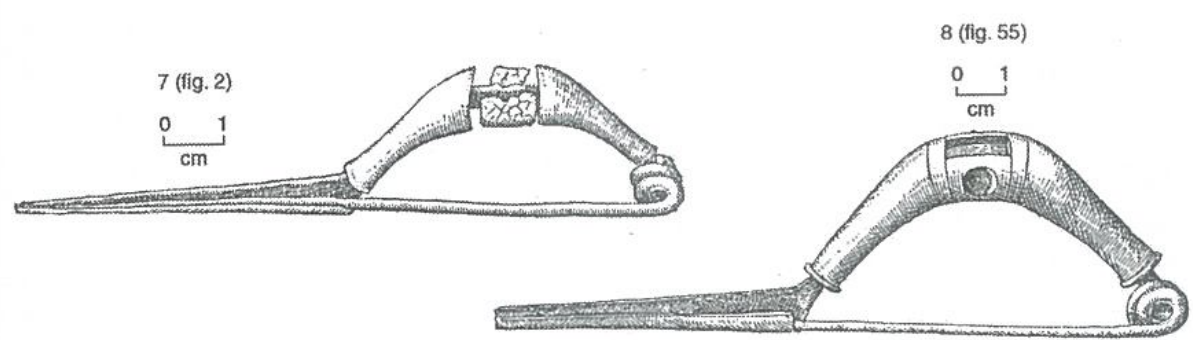

Image from: Shepherd, G. (1999) 'Fibulae and Females', in Tsetskhladze, G. R. (ed) Ancient Greeks West and East, Leiden: Brill, p. 279. 
Figure 4: Area of inhabitation at Pithekoussai

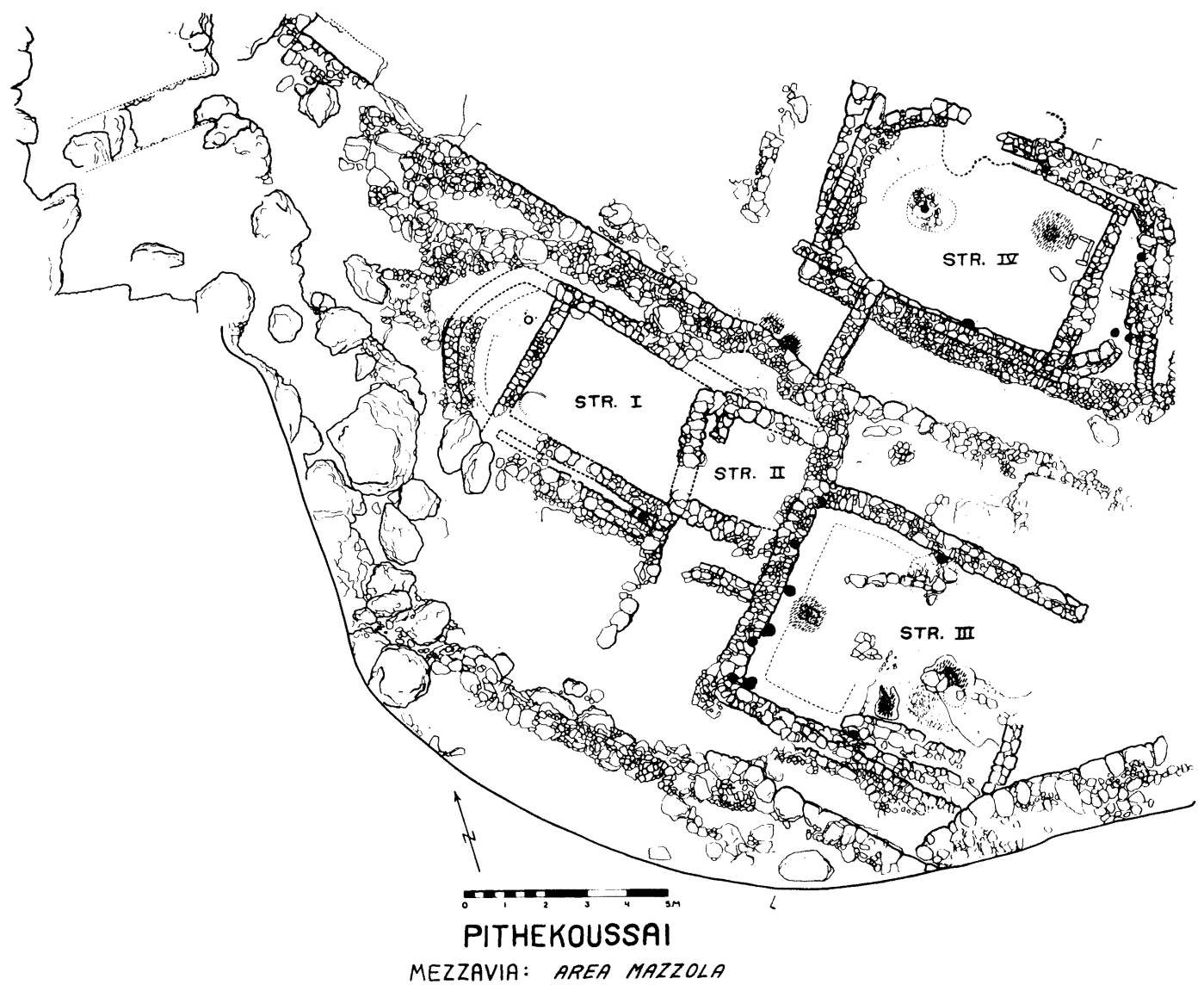

Image from: Buchner, G. (1970-71) 'Recent Work at Pithekoussai (Ischia), 196571', Archaeological Reports 17, p. 65.

\section{Figure 5: Miscast fibula found in Structure IV}

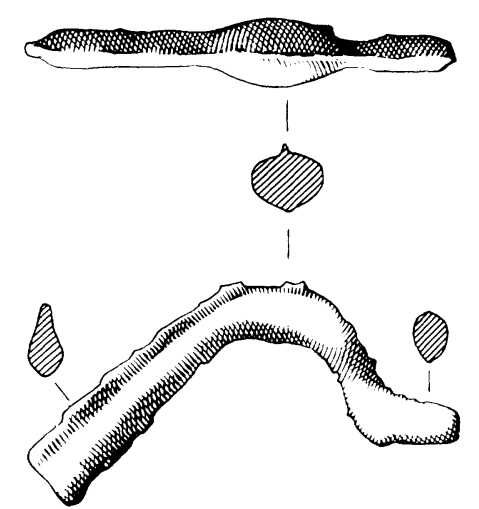

Image from: Buchner, G. (1970-71) 'Recent Work at Pithekoussai (Ischia), 196571', Archaeological Reports 17, p. 66. 
Figure 6: Kupara graffito from Morgantina

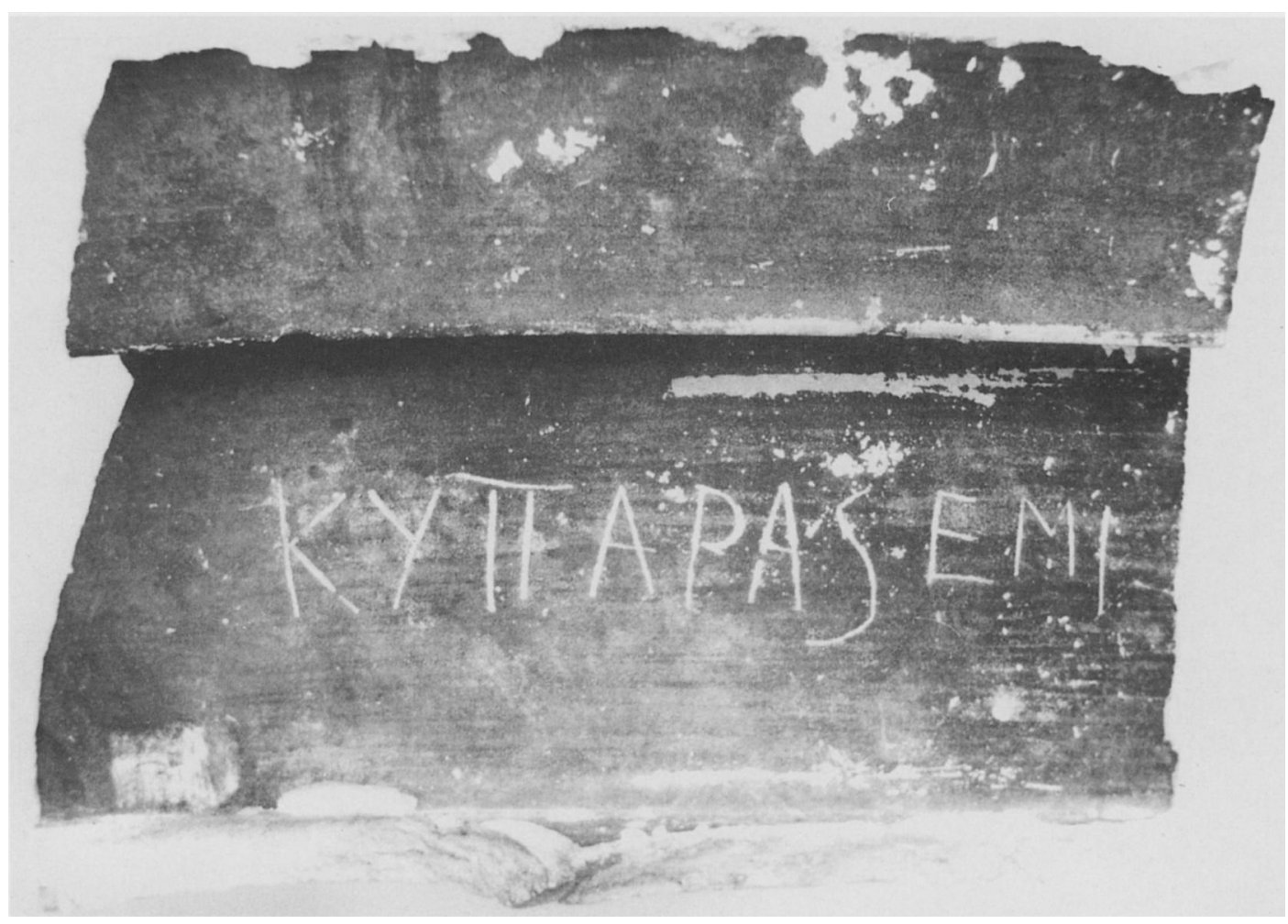

Image from: Antonaccio, C. M. \& Neils, J. (1995) 'A New Graffito from Archaic Morgantina', Zeitschrift für Papyrologie und Epigraphik 105, p. 277. 
Figure 7: CPS 1 - Libyan bust
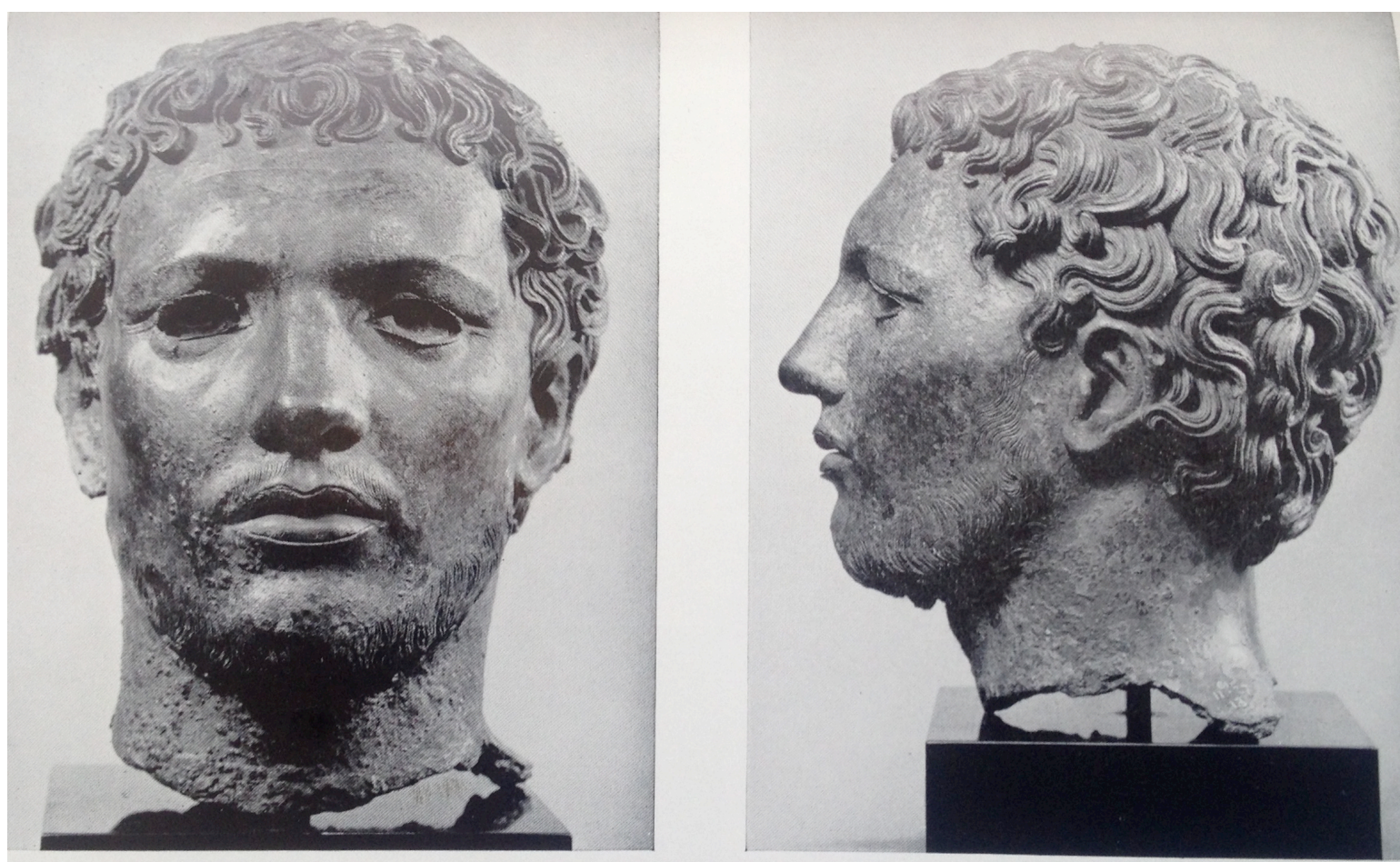

I-2. No. I. Bronze head of a Libyan, London, British Museum. Second half of 4 th c. B.c.

Figure 8: CPS 189, 190 - Cyrenaean busts showing a mixture of Greek and Libyan features

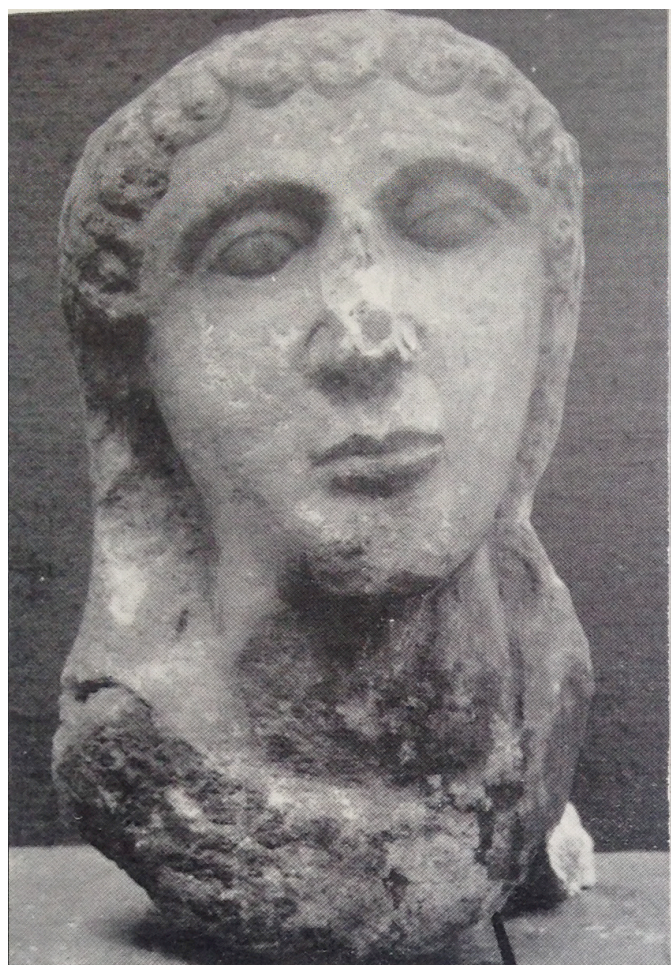

I. No. 189

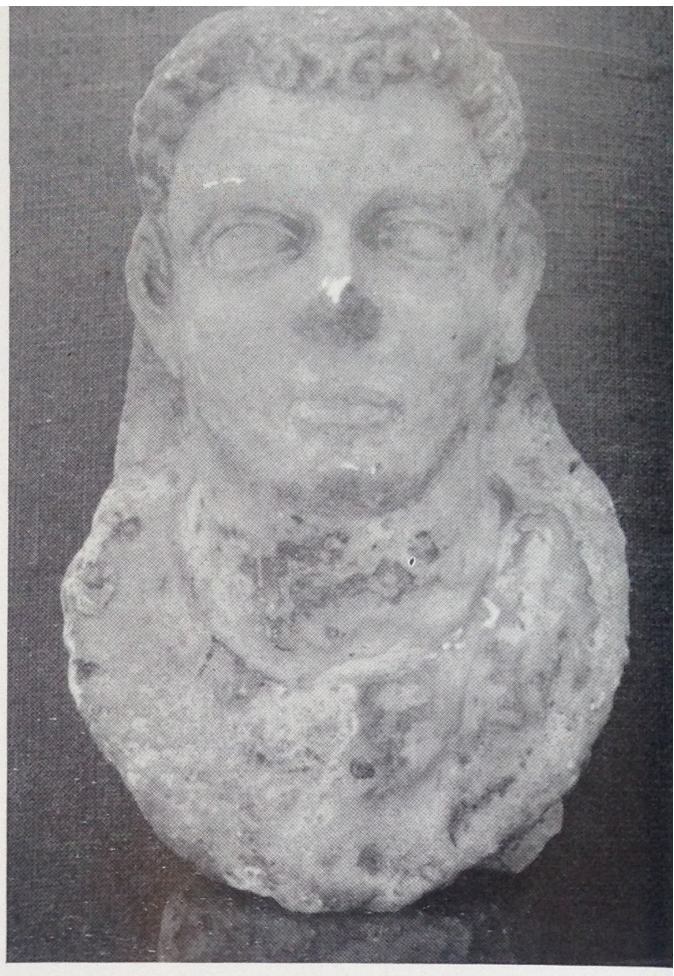

2. No. 190 
Figure 9: CPS 191 - Cyrenaean bust showing a mixture of Greek and Libyan features

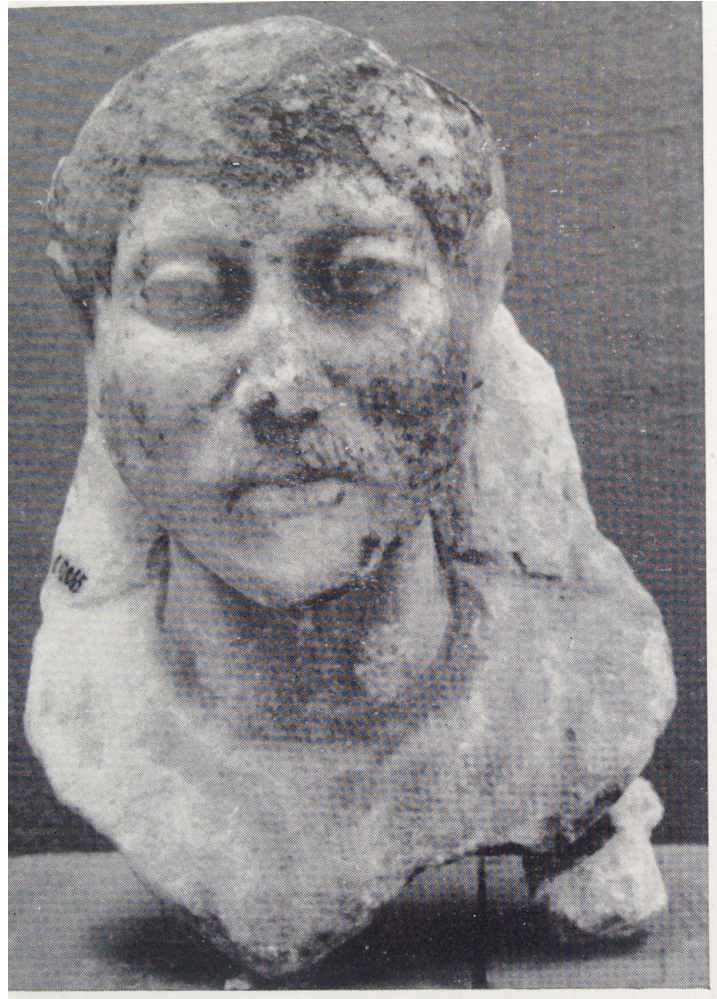

3. No. I9I

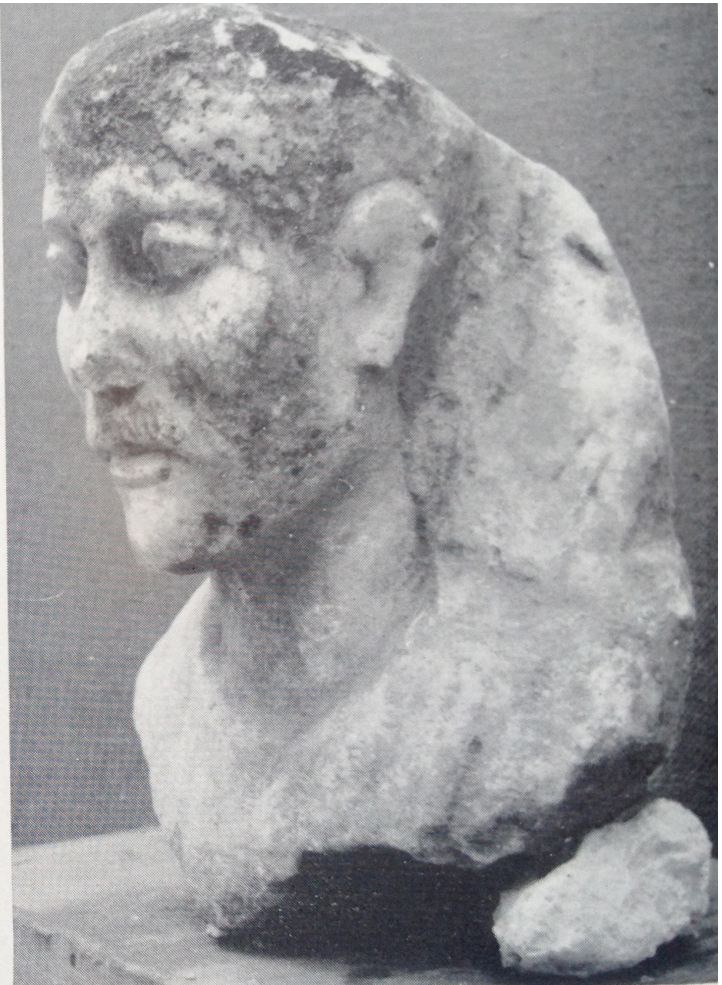

4. No. I9I 
Figure 10: Cyrenaean relief showing a mixture of Greek and Libyan aspects

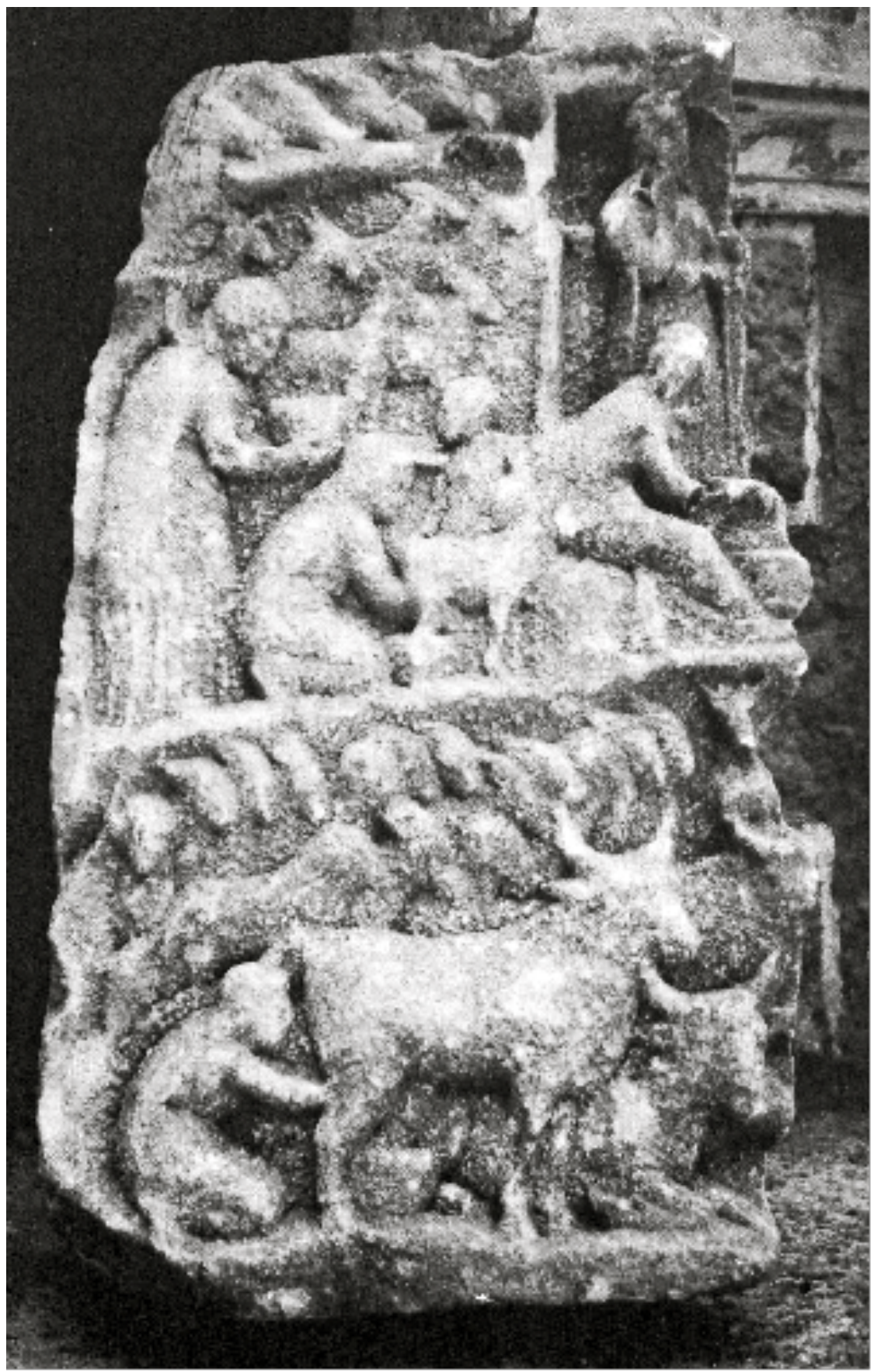

Image from: Wanis, S. (1992) 'A New Relief from Cyrene with a Libyan Scene', Libyan Studies 23, p. 42 . Unpublished, $77 \mathrm{~cm}$ high, $45 \mathrm{~cm}$ wide, $22 \mathrm{~cm}$ deep. 
Figure 11: Examples of dugouts in the Black Sea
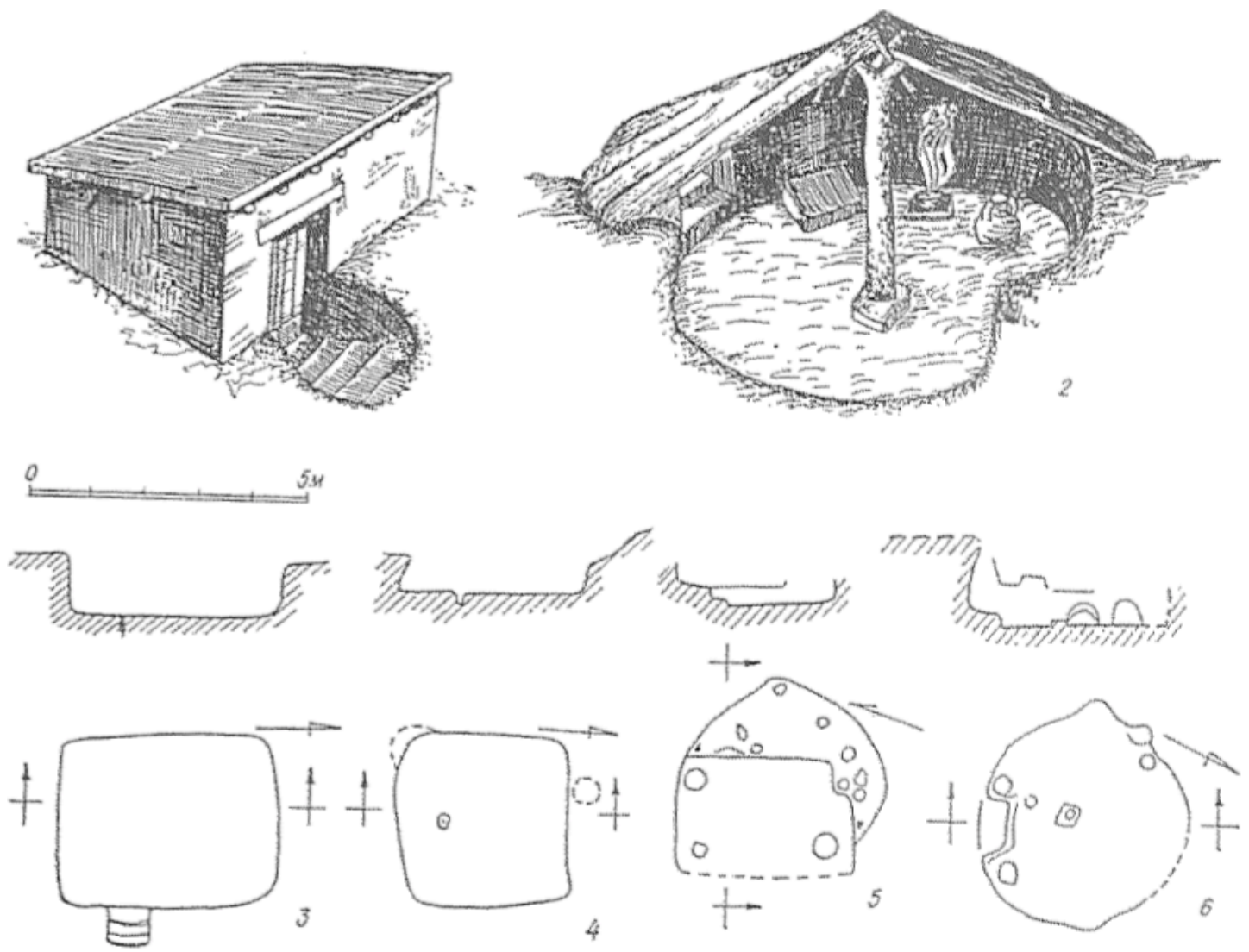

Image from: Kuznetsov, V. D. (1999) 'Early Types of Greek Dwelling Houses in the North Black Sea' in Tsetskhladze, G. R. (ed) Ancient Greeks West and East, Leiden: Brill, p. 543. 


\section{BIBLIOGRAPHY}

Albanese-Procelli, R. M. (1996) 'Greeks and Indigienous People in Eastern Sicily: Forms of Interaction and Acculturation' in Leighton, R. (ed) Early Societies in Sicily: New Developments in Archaeological Research, London: Accordia Research Centre, 167-176.

Angel, J. L. (1972) 'Ecology and Population in the Eastern Mediterranean', World Archaeology 4 (1), 88-105.

Antonaccio, C. (1993) 'Writing and Naming at Archaic Morgantina', American Journal of Archaeology 97, 352.

Antonaccio, C. (1997) 'Urbanization at Archaic Morgantina', Acta Hyperborea 7, 167-193.

Antonaccio, C. (2001) 'Ethnicity and Colonization' in Malkin, I. (ed) Ancient Perceptions of Greek Ethnicity, Washington D.C.: Center for Hellenic Studies, 113-158.

Antonaccio, C. (2003) 'Hybridity and the Cultures within Greek Culture' in Dougherty, C \& Kurke, L (eds) The Cultures Within Ancient Greek Culture: Contact, Conflict, Collaboration, Cambridge: Cambridge University Press, 57-74.

Antonaccio, C. (2005) 'Excavating Colonization' in Hurst, H \& Owen, S (eds) Ancient Colonizations: Analogy, Similarity and Difference, London: Duckworth, 97-113.

Antonaccio, C. (2007) 'Colonization: Greece on the Move, 900-480' in Shapiro, H. A. (ed) The Cambridge Companion to Archaic Greece, New York: Cambridge University Press, 201-224.

Antonaccio, C. \& Neils, J. (1995) 'A New Graffito from Archaic Morgantina', Zeitschrift für Papyrologie und Epigraphik 105, 261-277.

Applebaum, S. (1979) Jews and Greeks in Ancient Cyrene, Leiden: Brill.

Armayor, O. K. (1978) 'Did Herodotus Ever Go to the Black Sea?', Harvard Studies in Classical Philology 82, 45-62.

Astour, M. C. (1985) 'Ancient Greek Civilization in Southern Italy', Journal of Aesthetic Education 19 (1), 23-37.

Attema, P. (2008) 'Conflict or Coexistence? Remarks on Indigenous Settlement and Greek Colonization in the Foothills and Hinterland of the Sibaritide (Northern Calabria, Italy)' in Bilde, P. G. \& Petersen, J. H. (eds) Meetings 
of Cultures - Between Conflicts and Coexistence, Aarhus: Aarhus University Press, 67-100.

Aubet, M. E. (1993) Phoenicians and the West: Politics, Colonies, and Trade, Cambridge: Cambridge University Press.

Austin, M. (2008) 'The Greeks in Libya' in Tsetskladze, G. R. (ed) Greek Colonisation: An Account of Greek Colonies and Other Settlements Overseas. Volume Two, Leiden: Brill, 187-218.

Becker, M. J. (1986) 'An Ethnographical and Archaeological Survey of Unusual Mortuary Procedures as a Reflection of Cultural Diversity: Some Suggestions for the Interpretation of the Human Skeletal Deposits from Excavations at Entella, Sicily, Italy', La Parola del Pasato: Rivista di Studi Antichi 226, 31-56.

Becker, M. J. (1992) 'A Summary of the Analysis of Cremated Human Skeletal Remains from the Greek Colony of Pithekoussai at Lacco Ameno, Ischia, Italy', Old World Archaeology Newsletter 16 (1), 15-23.

Becker, M. J. (1995) 'Human Skeletal Remains from the Pre-Colonial Greek Emporium of Pithekoussai on Ischia (NA): Culture Contact in Italy from the Early VIII to II Century B.C.' in Christie, N. (ed) Settlement and Economy in Italy 1500 B.C. - A.D. 1500, Oxford: Oxbow Books, 273-282.

Becker, M. J. (1996) 'The Human Skeletons from the Archaic Cemeteries' in Lyons, C. The Archaic Cemeteries. Morgantina Studies, Volume 5, New Jersey: Princeton University Press, 227-237.

Blakeway, A. A. (1932-3) 'Prolegomena to the Study of Greek Commerce with Italy, Sicily and France in the Eighth and Seventh centuries BC', British School at Athens 33, 170-208.

Boardman, J. (1980) The Greeks Overseas, London: Thames \& Hudson Ltd.

Boardman, J. (1991) 'Early Greek Pottery on Black Sea Sites?', Oxford Journal of Archaeology 10 (3), 387-390.

Boardman, J. (1994) 'Orientalia and Orientals on Ischia' in D'Agnostino \& Ridgway, D. AПOIKIA - Scritti in onore di Giorgio Buchner, Naples: Istituto Universitario Orientale, 95-100.

Boardman, J. (1998) 'Olbia and Berezan: The Early Pottery' in Tsetskhladze, G. R. (ed) Greek Colonisation of the Black Sea Area, Stuttgart: Steiner, 201204.

Boardman, J. (2001) 'Aspects of "Colonization", Bulletin of the American Schools of Oriental Research 322, 33-42. 
Boardman, J. \& Hammond, N. G. L. (eds) (1982) The Cambridge Ancient History. Volume III, Part 3. The Expansion of the Greek World, Eighth to Sixth Centuries B.C., $2^{\text {nd }}$ ed, Cambridge: Cambridge University Press.

Bowden, H. (1996) 'The Greek Settlement and Sanctuaries at Naukratis: Herodotus and Archaeology' in Hansen, M. H. \& Raaflaub, K. (eds) More Studies in the Ancient Greek Polis, Copenhagen: Franz Steiner Verlag, 1738.

Bradley, G. \& Wilson, J. P. (eds) (2006) Greek and Roman Colonization: Origins, Ideologies, and Interactions, Swansea: The Classical Press of Wales.

Brauer, G. C. Jr. (1986) Taras: Its History and Coinage, New York: Caratzas Publishing.

Braund, D. (1998) 'Writing and Re-Inventing Colonial Origins: Problems from Colchis and the Bosporus' in Tsetskhladze, G. R. (ed) Greek Colonisation of the Black Sea Area, Stuttgart: Steiner, 287-296.

Buchner, G. (1966) 'Pithekoussai, Oldest Greek Colony in the West', Expedition 8 (4), 4-12.

Buchner, G. (1970-71) 'Recent Work at Pithekoussai (Ischia), 1965-1971', Archaeological Reports 17, 63-67.

Buchner, G. (1979) 'Early Orientalizing Aspects of the Euboean Connection' in Ridgway, D \& F. (eds) Italy Before the Romans, London: Academic Press Inc. Ltd., 129-144.

Buchner, G. \& Ridgway, D. (1993) Pithekoussai 1: La Necropoli. Tombe 1-723 Scanate dal 1952 al 1961, Rome: Monumenti Antichi.

Burstein, S. M. (1974) Outpost of Hellenism: The Emergence of Heraclea on the Black Sea, California: University of California Press.

Buyskikh, S. B. (2007) 'Contacts Between Greeks and Non-Greeks on the Lower Bug in the Sixth and Fifth Centuries BC' in Braund, D. \& Kryzhitskii, S. D. (eds) Classical Olbia and the Scythian World: From the Sixth Century $B C$ to the Second Century AD, Oxford: Oxford University Press, 23-36.

Calame, C. (1990) 'Narrating the Foundation of a City: The Symbolic Birth of Cyrene' in Edmunds, L. (ed) Approaches to Greek Myth, Baltimore: John Hopkins University Press, 275-341.

Camp, J. M. (1979) 'A Drought in the Late Eighth Century B.C.', Hesperia 48 (4), 397-411. 
Carpenter, R. (1948) 'The Greek Penetration of the Black Sea', American Journal of Archaeology 52 (1), 1-10.

Carter, J. C. (1981) 'Rural Settlement at Metaponto' in Barker, G. \& Hodges, R. (eds) Archaeology and Italian Society: Prehistoric, Roman and Medieval Studies, Oxford: BAR International Series 102, 167-178.

Carter, J. C. (1993) 'Taking Possession of the Land: Early Colonization in Southern Italy' in Scott, R. \& Scott, A. R. (eds) Eius Virtutis Studiosi: Classical and Post-Classical Studies in Memory of Frank Edward Brown, Washington D.C.: National Gallery of Art, 342-67.

Carter, J. C. (1998) The Chora of Metaponto: The Necropoleis. Volumes One and Two, Austin: University of Texas Press.

Carter, J. C. (2006) Discovering the Greek Country at Metaponto, Ann Arbor: University of Michigan Press.

Cawkwell, G. L. (1992) ‘Early Colonisation’, Classical Quarterly 42 (2), 289-303.

Chapman, J. \& Dolukhanov, P. (eds) (1997) Landscapes in Flux: Central and Eastern Europe in Antiquity, Oxford: Oxbow Books.

Coja, M. (1990) 'Greek Colonists and Native Populations in Dobruja (Moesia Inferior): The Archaeological Evidence' in Descoeudres, J. P. (ed) Greek Colonists and Native Populations, Oxford: Oxford University Press, 157168.

Coldstream, J. N. (1993) 'Mixed Marriages at the Frontiers of the Early Greek World', Oxford Journal of Archaeology 12, 89-108.

Coldstream, J. N. (1994) 'Prospectors and Pioneers: Pithekoussai, Kyme and Central Italy' in Tsetskhladze, G. R \& de Angelis, F (eds) The Archaeology of Greek Colonisation, Oxford: Oxford University Committee for Archaeology, 47-59.

Coldstream, J. N. (1995) 'Euboean Geometric Imports from the Acropolis of Pithekoussai', The Annual of the British School at Athens 90, 251-267.

Coldstream, J. N. (2003) Geometric Greece 900-700 BC, Oxford: Routledge, $2^{\text {nd }}$ ed.

Cook, R. M. (1962) 'Reasons for the Foundation of Ischia and Cumae', Historia $11(1), 113-114$.

Crielaard, J. P. (1992-1993) 'How the West was Won: Euboeans vs. Phoenicians', Hamburger Beiträge zur Archäologie 19/20, 235-260. 
d'Agnostino, B. (1996) 'The Impact of the Greek Colonies on the Indigenous Peoples of Campania' in Pugliese Carratelli, G. (ed) The Western Greeks. Classical Civilization in the Western Mediterranean, London: Thames \& Hudson, 533-540.

d'Agnostino, B. \& Ridgway, D. (1994) AПOIKIA - Scritti in onore di Giorgio Buchner, Naples: Istituto Universitario Orientale.

Dalby, A. (1992) 'Greeks Abroad: Social Organisation and Food Among the Ten Thousand', Journal of Hellenic Studies 112, 16-30.

Danner, P. (1997) 'Megara, Megara Hyblaea, and Selinus: The Relationship Between the Town Planning of a Mother City, a Colony, and a Sub-Colony in the Archaic Period', Acta Hyperborea 7, 143-165.

De Angelis, F. (1994) 'The Foundation of Selinous: Overpopulation or Opportunities?' in Tsetskhladze, G. R \& de Angelis, F (eds) The Archaeology of Greek Colonisation, Oxford: Oxford University Committee for Archaeology, 87-110.

De Angelis, F. (1998) 'Ancient Past, Imperial Present: The British Empire in T. J. Dunbabin's The Western Greeks', Antiquity 72, 539-549.

De Angelis, F. (2003a) Megara Hyblaia and Selinous: The Development of Two Greek City-States in Archaic Sicily, Oxford: Oxford University School of Archaeology.

De Angelis, F. (2003b) 'Equations of Culture: The Meeting of Natives and Greeks in Sicily (ca 750-450 B.C.)', Ancient West and East 2 (1), 19-50.

De Angelis, F. (2009) 'Colonies and Colonization' in Boys-Stones, G, Graziosi, B, \& Vasunia, P. (eds) The Oxford Handbook of Hellenic Studies, Oxford: Oxford University Press, 48-64.

De Angelis, F. (2011) 'Ancient Greek Colonization in the $21^{\text {st }}$ Century: Some Suggested Directions', Bollettino di Archeologia. Proceedings of the $17^{\text {th }}$ International Congress of Classical Archaeology, Rome, September 22-26 2008, 18-30.

Demetriou, D. (2011) 'What is an Emporion? A Reassessment', Historia 60 (3), 255-272.

De Polignac, F. (2005) 'Forms and Processes: Some Thoughts on the Meaning of Urbanization in Early Archaic Greece' in Osborne, R. \& Cunliffe, B. (eds) Mediterranean Urbanization 800-600 BC, Oxford: Oxford University Press, 45-69. 
Desborough, V. (1976) 'The Background to Euboean Participation in Early Greek Maritime Enterprise' in Emmison, F. \& Stephens, R. (eds) Tribute to an Antiquary. Essays Presented to Marc Fitch, London: Leopard's Head Press Limited, 27-40.

Descoeudres, J. P. (ed) (1990) Greek Colonists and Native Populations, Oxford: Oxford University Press.

DeVoto, J. G. (2005) 'Megarian Colonies in Sicily’, Ancient World 36 (1), 90-106.

Dewald, C. (1980) 'Biology and Politics: Women in Herodotus' Histories', Pacific Coast Philology 15, 11-18.

Dietler, M. (2010) Archaeologies of Colonialism: Consumption, Entanglement, and Violence in Ancient Mediterranean France, Berkeley: University of California Press.

Dietler, M. \& Lopez-Ruiz, C. (eds) (2009) Colonial Encounters in Ancient Iberia: Phoenicians, Greek, and Indigenous Relations, Chicago: The University of Chicago Press.

Dittenberger, W. (1903-05) Orientis Graeci Inscriptiones Selectae, Leipzig: Herzel.

Di Vita, A. (1996) 'Urban Planning in Ancient Sicily' in Pugliese Carratelli, G. (ed) The Western Greeks. Classical Civilization in the Western Mediterranean, London: Thames \& Hudson, 263-307.

Docter, R. F. \& Niemeyer, H. G. (1994) 'Pithekoussai: the Carthaginian Connection on the Archaeological Evidence of Euboeo-Phoenician Partnership in the $8^{\text {th }}$ and $7^{\text {th }}$ Centuries B.C.' in D'Agnostino \& Ridgway, D. (eds) AПOІKIA - Scritti in onore di Giorgio Buchner, Naples: Istituto Universitario Orientale, 101-116.

Domanskij, J. V. \& Marcenko, K. K. (2003) 'Towards Determining the Chief Function of the Settlement of Borysthenes' in Bilde, P. G., Hojte, J. M. \& Stolba, V. F. (eds) The Cauldron of Ariantas, Studies Presented to A. N. Sceglov on the Occasion of his $70^{\text {th }}$ Birthday, Aarhus: Aarhus University Press, 29-36.

Dominguez, A. J. (1999) 'Ephesos and Greek Colonization' in Krinzinger, K. \& Friesinger, H. (eds) 100 Jahre oi Sterreichische Forschungen in Ephesos, Vienna, 75-80.

Dominguez, A. J. (2006) 'Greeks in the Iberian Peninsula' in Tsetskladze, G. R. (ed) Greek Colonisation: An Account of Greek Colonies and Other Settlements Overseas. Volume One, Leiden: Brill, 429-505. 
Dougherty, C. (1992) 'When Rain Falls From the Clear Blue Sky: Riddles and Colonization Oracles', Classical Antiquity 11 (1), 28-44.

Dougherty, C. (1993a) The Poetics of Colonization: From City to Text in Archaic Greece, Oxford: Oxford University Press.

Dougherty, C. (1993b) 'It's Murder to Found a Greek Colony' in Dougherty, C. \& Kurke, L. Cultural Poetics in Archaic Greece: Cult, Performance, Politics, Cambridge: Cambridge University Press, 178-198.

Dougherty, C. (1994) 'Archaic Greek Foundation Poetry: Questions of Genre and Occasion', Journal of Hellenic Studies 114, 35-46.

Dougherty, C. (2001) The Raft of Odysseus: The Ethnographic Imagination of Homer's Odyssey, Oxford: Oxford University Press.

Drews, R. (1976) 'The Earliest Greek Settlements on the Black Sea', Journal of Hellenic Studies 96, 18-31.

Dunbabin, T. J. (1948) The Western Greeks, Oxford: Oxford University Press.

Dunbabin, T. J. (1957) The Greeks and their Eastern Neighbours, London: Society for the Promotion of Hellenic Studies.

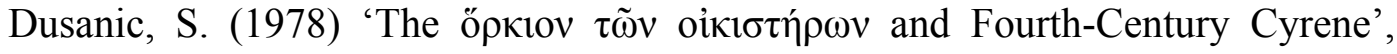
Chiron 8, 55-76.

Eikeland, K. S. (2006) Indigenous Households: Transculturation of Sicily and Southern Italy in the Archaic Period, Goteborg: Goteborg University Press.

Figueria, T. J. (1984) 'Karl Polanyi and Ancient Greek Trade: The Port of Trade', Ancient World 10, 15-30.

Finley, M. I. (1962) 'The Black Sea and Danubian Regions and the Slave Trade in Antiquity’, Klio 40, 51-59.

Finley, M. I. (1968) Ancient Sicily to the Arab Conquest, London: Chatto \& Windus.

Finley, M. I. (1976) 'Colonies - An Attempt at a Typology', Transactions of the Royal Historical Society 26, 167-188.

Fischer-Hansen, T. (1996) 'The Earliest Town Planning of the Western Greek Colonies With Special Regard to Sicily' in Hansen, M. H. (ed) Introduction to an Inventory of Poleis, Copenhagen: Munksgaard, 317-373.

Fitzjohn, M. (2007) 'Equality in the Colonies: Concepts of Equality in Sicily during the Eighth to Six Centuries BC', World Archaeology 39 (2), 215228. 
Frederiksen, R. (1999) 'From Death to Life: The Cemetery of Fusco and the Reconstruction of Early Colonial Society' in Tsetskhladze, G. (ed) Ancient Greeks West and East, Leiden: Brill, 229-266.

Freeman, C. (1999) The Greek Achievement. The Foundation of the Western World, New York: Penguin.

Garlan, Y. (1988) Slavery in Ancient Greece, Ithaca: Cornell University Press.

Gjerstad, E. (1979) 'A Cypro-Greek Royal Marriage in the $8^{\text {th }}$ Century BC' in Karageorghis, V. (ed) Studies Presented in Memory of Porphyrios Dikaios, Cyprus: Lions Club of Nicosia, 89-93.

Glare, P. G. W. (1968) Oxford Latin Dictionary, Oxford: Oxford University Press.

Gomez, F. J. (1993) 'Iberia as a Barbarian Land: Perception of a Cultural Stereotype', The Ancient World 24 (2), 131-142.

Gosden, C. (2004) Archaeology and Colonialism: Cultural Contact from 5000 BC to the Present, Cambridge: Cambridge University Press.

Graham, A. J. (1958) 'The Date of the Greek Penetration of the Black Sea', Bulletin of the Institute of Classical Studies 5, 25-42.

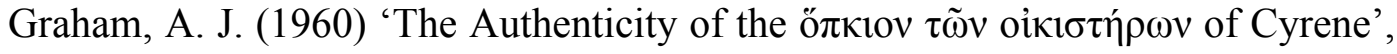
Journal of Hellenic Studies 80, 94-111.

Graham, A. J. (1964) Colony and Mother City in Ancient Greece, Manchester: Manchester University Press.

Graham, A. J. (1971) 'Patterns in Early Greek Colonisation', Journal of Hellenic Studies 91, 35-47.

Graham, A. J. (1981-82) 'Religion, Women and Greek Colonization' in Religione e citta nel mondo antica, Atti, Centro ricerche e documentazione sull'antichita classica 11, 293-314.

Graham, A. J. (1982) 'The Colonial Expansion of Greece' in Boardman, J. \& Hammond, N. G. L. (eds) The Cambridge Ancient History, $2^{\text {nd }}$ ed, Volume III, Part 3. The Expansion of the Greek World, Eighth to Sixth Centuries B.C., Cambridge: Cambridge University Press, 83-162.

Graham, A. J. (1984) 'Commercial Interchanges between Greeks and Natives', Ancient World 10, 3-10.

Graham, A. J. (1988) 'Megara Hyblaea and the Sicels' in Lordkipanidze, O. (ed) Local Ethnopolitical Entities of the Black Sea Littoral in the Seventh to Fourth Centuries BC, Tbilisi, 304-321. 
Graham, A. J. (1990) 'Pre-Colonial Contacts: Questions and Problems' in Descoeudres, J. P. (ed) Greek Colonists and Native Populations, Oxford: Oxford University Press, 45-60.

Graham, A. J. (1994/2001) 'Greek and Roman Settlements on the Black Sea Coasts: Historical Background' in Graham. A. J. Collected Papers on Greek Colonization, Leiden: Brill, 139-148.

Graham, A. J. (1995) 'The Odyssey, History, and Women' in Cohen, B. (ed) The Distaff Side: Representing the Female in Homer's Odyssey, Oxford: Oxford University Press, 3-16.

Graham, A. J. (2001) Collected Papers on Greek Colonization, Leiden: Brill.

Graham, H. F. (1961) 'Soviet Classical Scholarship and the Black Sea Region', The Classical Journal 56 (5), 194-202.

Greaves, A. M. (1998) 'Dionysius of Halicarnassus, Antiquitates Romanae 2.30 and Herodotus 1.146', Classical Quarterly 48 (2), 572-574.

Greco, E. (2006) 'Greek Colonisation in Southern Italy: A Methodological Essay' in Tsetskhasze, G. R. (ed) Greek Colonisation: An Account of Greek Colonies and Other Settlements Overseas. Volume One, Leiden: Brill, 169200.

Gwynn, A. (1918) 'The Character of Greek Colonisation', The Journal of Hellenic Studies 38, 88-123.

Hackens, T., Holloway, N. D., and Holloway, R. R. (eds) (1984) Crossroads of the Mediterranean, Providence: Brown University.

Hall, E. (1989) Inventing the Barbarian: Greek Self-Definition Through Tragedy, Oxford: Oxford University Press.

Hall, J. M. (1997) Ethnic Identity in Greek Antiquity, Cambridge: Cambridge University Press.

Hall, J. M. (2004) 'How “Greek” were the Early Western Greeks?' in Lomas, K. (ed) Greek Identity in the Western Mediterranean. Papers in Honour of Brian Shefton, Leiden: Brill, 35-54.

Hall, J. M. (2006) 'Foundation Stories' in Tsetskhladze, G. R. (ed) Greek Colonisation: An Account of Greek Colonies and Other Settlements Overseas. Volume Two, Leiden: Brill, 383-426.

Hall, J. M. (2007) A History of the Archaic Greek World, ca. 1200-479 BCE, Massachusetts: Blackwell Publishing Ltd. 
Hansen, M. H. (ed) (1996) Introduction to an Inventory of Poleis, Copenhagen: The Royal Danish Academy of Sciences and Letters.

Hansen, M. H. (1997) 'Emporion: A Study of the Use and Meaning of the Term in the Archaic and Classical Periods' in Nielsen, T. H. (ed) Yet More Studies in the Ancient Greek Polis, Stuttgard: Steiner Verlag, 83-105.

Hansen, M. H. \& Nielsen, T. H. (eds) (2004) An Inventory of Archaic and Classical Poleis, New York: Oxford University Press.

Hansen, P. A. (1976) 'Pithecusan Humour. The Interpretation of 'Nestor's Cup' Reconsidered', Glotta 54, 25-44.

Heinen, H. (2001) 'Greeks, Iranians and Romans on the Northern Shore of the Black Sea' in Tsetskhladze, G. R. (ed) North Pontic Archaeology: Recent Discoveries and Studies, Leiden: Brill, 1-23.

Henneberg, M. \& Henneberg, R. J. (2001) 'Analysis of Human Skeletal and Dental Remains from Metaponto $\left(7^{\text {th }}-2^{\text {nd }} C\right.$ BC)', AttiTaranto 40, 461474.

Henneberg, R. J. (1998) Dental Health and Affiliations of Inhabitants of the Ancient Greek Colony in Metaponto, Italy $\left(6^{\text {th }}-3^{\text {rd }}\right.$ century BC), Johannesburg: University of Witwatersrand.

Hind, J. (1983-84) 'Greeks and Barbarian Peoples on the Shores of the Black Sea', Archaeological Reports 30, 71-97.

Hind, J. (1992-93) 'Archaeology of the Greeks and Barbarian Peoples around the Black Sea (1982-1992)', Archaeological Reports 39, 82-112.

Hind, J. (1997) 'Colonies and Ports-of-Trade on the Northern Shores of the Black Sea: Borysthenes, Kremnoi and the "Other Pontic Emporia" in Herodotos' in Nielsen, T. H. (ed) Yet More Studies in the Ancient Greek Polis, Stuttgard: Steiner Verlag, 107-116.

Hind, J. (1998) 'Megarian Colonisation in the Western Half of the Black Sea (Sister and Daughter Cities of Herakleia)' in Tsetskhladze, G. R. (ed) Greek Colonisation of the Black Sea Area, Stuttgart: Steiner, 131-152.

Hodge, A. T. (1982) ‘Massalia - The Truth', Classical Views 1, 164-173.

Hodos, T. (1999) 'Intermarriage in the Western Greek Colonies', Oxford Journal of Archaeology 18 (1), 61-78.

Hodos, T. (2006) Local Responses to Colonization in the Iron Age Mediterranean, Oxford: Routledge. 
Hojte, J. M. (2008) 'The Cities That Never Were: Failed Attempts at Colonization in the Black Sea' in Bilde, P. G. \& Petersen, J. H. (eds) Meetings of Cultures - Between Conflicts and Coexistence, Aarhus: Aarhus University Press, 149-162.

Holloway, R. (1981) 'Motives for Colonisation' in Holloway, R. (ed) Italy and the Aegean 3000-700 BC, Louvain-la-Neuve: Institut Superieur d'Archeologie et d'Histoire de l'Art, College Erasme, 133-154.

Holloway, R. R. (1991) The Archaeology of Ancient Sicily, London: Routledge.

Hornblower, S. \& Spawforth, A. (2012) The Oxford Classical Dictionary, Oxford: Oxford University Press, $4^{\text {th }}$ ed.

Humphreys, S. C. (1978) Anthropology and the Greeks, London: Routledge \& Kegan Paul.

Hurst, H. \& Owen, S. (eds) (2005) Ancient Colonizations: Analogy, Similarity and Difference, London: Duckworth.

Isaac, B. (2004) The Invention of Racism in Classical Antiquity, New Jersey: Princeton University Press.

Jeffery, L. H. (1961) 'The Pact of the First Settlers at Cyrene', Historia 10 (2), 139-147.

Jones, A. H. M. (1940) The Greek City from Alexander to Justinian, Oxford: Oxford University Press.

Jones, S. (1997) The Archaeology of Ethnicity, London: Routledge.

Just, R. (1989) Women in Athenian Law and Life, London: Routledge.

Karlsson, L. (1989) 'Some Notes on the Fortifications of Greek Sicily', Opuscula Romana 17 (6), 77-89.

Kirk, G. S. (1949) 'Ships on Geometric Vases', Annual of the British School at Athens 44, 93-153.

Kirkwood, G. (1981) 'Pythian 5.72-6, 9.90-2, and the Voice of Pindar', Illinois Classical Studies 6 (1), 12-23.

Klein, J. (1972) 'A Greek Metalworking Quarter of the Eighth Century BC: Excavations on Ischia', Expedition 14, 34-39.

Koromila, M. (1991) The Greeks in the Black Sea, Athens: Panorama.

Kryzhitskii, S. D. (1997) 'The Landscape of the North Pontic City-States - a Case Study From Olbia' in Chapman, J. \& Dolukhanov, P. (eds) (1997) 
Landscapes in Flux: Central and Eastern Europe in Antiquity, Oxford: Oxbow Books, 101-114.

Kryzhitskii, S. D. (2006) 'The Rural Environs of Olbia: Some Problems of Current Importance' in Bilde, P. G. \& Stolba, V. F. (eds) Surveying the Greek Chora. The Black Sea Region in a Comparative Perspective, Aarhus: Aarhus University Press, 99-114.

Kryzhitskii, S. D. (2007) 'Criteria for the Presence of Barbarians in the Population of Early Olbia' in Braund, D. \& Kryzhitskii, S. D. (eds) Classical Olbia and the Scythian World: From the Sixth Century BC to the Second Century $A D$, Oxford: Oxford University Press, 17-22.

Kurtz, D. C. \& Boardman, J. (1971) Greek Burial Customs, New York: Cornell University Press.

Kuznetsov, V. D. (1999) 'Early Types of Greek Dwelling Houses in the North Black Sea' in Tsetskhladze, G. R. (ed) Ancient Greeks West and East, Leiden: Brill, 531-564.

La Rosa, V. (1996) 'The Impact of the Greek Colonies on the Non-Hellenic Inhabitants of Sicily' in Pugliese Carratelli, G. (ed) The Western Greeks. Classical Civilization in the Western Mediterranean, London: Thames \& Hudson, 523-532.

Labaree, B. W. (1957) 'How the Greeks Sailed into the Black Sea', American Journal of Archaeology 61 (1), 29-33.

Laronde, A. (1990) 'Greeks and Libyans in Cyrenaica' in Descoeudres, J. P. (ed) Greek Colonists and Native Populations, Oxford: Oxford University Press, 169-180.

Leighton, R. (ed) (1996) Early Societies in Sicily: New Developments in Archaeological Research, London: Accordia Research Centre.

Leighton, R. (1999) Sicily Before History: An Archaeological Survey from the Palaeolithic to the Iron Age, New York: Cornell University Press.

Lewis, D., Jeffery, L., Erxleben, E. \& Hallof, K. (eds) (1981, 1994, 1998) Inscriptiones Graecae I: Inscriptiones Atticae Euclidis anno anteriores, Berlin: Berlin-Brandenburgische Akademie der Wissenschaften, $3^{\text {rd }}$ ed.

Liddell, H. G. \& Scott, R. (1968) A Greek-English Lexicon, Oxford: Claredon Press, $9^{\text {th }}$ ed, revised by Jones, H. S.

Liston, M. A. (2012) 'Reading the Bones: Interpreting the Skeletal Evidence for Women's Lives in Ancient Greece' in James, S. L. \& Dillon, S. (eds) $A$ 
Companion to Women in the Ancient World, West Sussex: Blackwell Publishing Ltd, 125-140.

Littman, R. J. (1974) The Greek Experiment: Imperialism and Social Conflict 800$400 B C$, London: Thames and Hudson.

Lomas, K. (ed) (2004a) Greek Identity in the Western Mediterranean: Papers in Honour of Brian Shefton, Leiden: Brill.

Lomas, K. (2004b) 'Introduction' in Lomas, K. (ed) Greek Identity in the Western Mediterranean. Papers in Honour of Brian Shefton, Leiden: Brill, 1-14.

Lorimer, H. L. (1950) Homer and the Monuments, London: Macmillan \& Co Ltd.

Luke, J. (2003) Ports of Trade, Al Mina and Geometric Greek Pottery in the Levant, BAR International Series 1100, Oxford: Archaeopress.

Lyons, C. L. (1996a) The Archaic Cemeteries. Morgantina Studies, Volume 5, New Jersey: Princeton University Press.

Lyons, C. L. (1996b) 'Sicel Burials at Morgantina: Defining Social and Ethnic Identities' in Leighton, R. (ed) Early Societies in Sicily: New Developments in Archaeological Research, London: Accordia Research Centre, 177-188.

Lyons, C. L. (2000) 'Gender and Burial in Early Colonial Sicily: The Case of Morgantina' in Donald, M. \& Hurcombe, L. (eds) Representations of Gender from Prehistory to the Present, Great Britain: Macmillan Press Ltd, 87-103.

Lyons, C. L. \& Papadopoulos, J. K. (eds) (2002) The Archaeology of Colonialism: Issues and Debates, Los Angeles: Getty Research Institute.

Maddoli, G. (1996) 'Cults and Religious Doctrines of the Western Greeks' in Pugliese Carratelli, G. (ed) The Western Greeks. Classical Civilization in the Western Mediterranean, London: Thames \& Hudson, 481-498.

Malkin, I. (1987) Religion and Colonization in Ancient Greece, Leiden: Brill.

Malkin, I. (1994a) Myth and Territory in the Spartan Mediterranean, Cambridge: Cambridge University Press.

Malkin, I. (1994b) 'Inside and Outside: Colonisation and the Formation of the Mother City' in D'Agnostino \& Ridgway, D. AПOIKIA - Scritti in onore di Giorgio Buchner, Naples: Istituto Universitario Orientale, 1-9.

Malkin, I. (1998) The Returns of Odysseus: Colonization and Ethnicity, California: University of California Press. 
Malkin, I. (2002a) 'A Colonial Middle Ground: Greek, Etruscan, and Local Elites in the Bay of Naples' in Lyons, C. L. \& Papadopoulos, J. K. (eds) The Archaeology of Colonialism, Los Angeles: Getty Research Institute, 151181.

Malkin, I. (2002b) 'Exploring the Validity of the Concept of 'Foundation': A Visit to Megara Hyblaia' in Gorman, V. B. \& Robinson, E. W. (eds) Oikistes: Studies in Constitutions, Colonies, and Military Power in the Ancient World. Offered in Honor of A. J. Graham, Leiden: Brill, 195-225.

Malkin, I. (2004) 'Postcolonial Concepts and Ancient Greek Colonization', Modern Language Quarterly 65 (3), 341-364.

Marshall, E. (1999) 'Sex and Paternity: Gendering the Foundation of Kyrene' in Foxhall, L. \& Salmon, J. (eds) When Men were Men, London: Routledge, 98-110.

Marshall, E. (2004) 'Women and the Transmission of Libyan Culture' in McHardy, F. \& Marshall, E. (eds) Women's Influence on Classical Civilisation, London: Routledge, 127-136.

Meiggs, R. \& Lewis, D. (eds) (1969) Selection of Greek Historical Inscriptions to the end of the Fifth Century BC, Oxford: Claredon.

Mertens, D. \& Greco, E. (1996) 'Urban Planning in Magna Graecia' in Pugliese Carratelli, G. (ed) The Western Greeks. Classical Civilization in the Western Mediterranean, London: Thames \& Hudson, 243-262.

Mierse, W. E. (1994) 'Ampurias: The Urban Development of a Graeco-Roman City on the Iberian Coast', Latomus 54, 790-805.

Mitchell, B. J. (2000) 'Cyrene: Typical or Atypical?' in Brock, R. \& Hodkinson, S. (eds) Alternatives to Athens, New York: Oxford University Press, 82102 .

Moller, A. (2000) Naukratis: Trade in Archaic Greece, New York: Oxford University Press Inc.

Moller, A. (2001) 'Naukratis, or How to Identify a Port of Trade' in Tandy, D. W. (ed) Prehistory and History: Ethnicity, Class and Political Economy, Montreal: Black Rose Books, 145-158.

Morakis, A. (2011) 'Thucydides and the Character of Greek Colonisation in Sicily', Classical Quarterly 61 (2), 460-492.

Morel, J. P. (1984) 'Greek Colonization in Italy and the West (Problems of Evidence of Interpretation)' in Hackens, T, Holloway, N. D, and Holloway, 
R. R. (eds) Crossroads of the Mediterranean, Providence: Brown University, 123-162.

Morel, J. P. (2006) 'Phocaean Colonisation' in Tsetskhasze, G. R. (ed) Greek Colonisation: An Account of Greek Colonies and Other Settlements Overseas. Volume One, Leiden: Brill, 358-428.

Morgan, C. \& Hall, J. (1996) 'Achaian Poleis and Achaian Colonisation' in Hansen, M. H. (ed) Introduction to an Inventory of Poleis, Copenhagen: Munksgaard, 164-232.

Morris, I. (1987) Burial and Ancient Society. The Rise of the Greek City-State, Cambridge: Cambridge University Press.

Morris, I. (1992) Death-Ritual and Social Structure in Classical Antiquity, Cambridge: Cambridge University Press.

Morris, I. (1996) 'The Absolute Chronology of the Greek Colonies in Sicily', Acta Archaologica Supplementum 67, 51-59.

Morrison, J. S. \& Williams, R. T. (1968) Greek Oared Ships, Cambridge: Cambridge University Press.

Murray, O. (1993) Early Greece, London: Fontana, $2^{\text {nd }}$ ed.

Nazarov, V. V. (1997) 'The Ancient Landscape of Berezan Island' in Chapman, J. \& Dolukhanov, P. (eds) (1997) Landscapes in Flux: Central and Eastern Europe in Antiquity, Oxford: Oxbow Books, 131-136.

Nevett, L. (1994) 'Separation or Seclusion? Towards an Archaeological Approach to Investigating Women in the Greek Household in the Fifth to Third Centuries BC' in Pearson, M. P. \& Richards, C. (eds) Architecture and Order: Approaches to Social Space, London: Routledge, 98-112.

Nevett, L. (1999) House and Society in the Ancient Greek World, Cambridge: Cambridge University Press.

Nielsen, T. H. (ed) (1997) Yet More Studies in the Ancient Greek Polis, Stuttgard: Steiner Verlag.

Oakley, J. H. \& Sinos, R. H. (1993) The Wedding in Ancient Athens, Wisconsin: The University of Wisconsin Press.

Osborne, R. (1998) 'Early Greek Colonization? The Nature of Greek Settlement in the West' in Fisher, N. \& Van Wees, H. (eds) Archaic Greece: New Approaches and New Evidence, London: Duckworth \& The Classical Press of Wales, 251-269. 
Osborne, R. (2009) Greece in the Making 1200-479 BC, Oxford: Routledge, $2^{\text {nd }}$ ed.

Owen, S. (2003) 'Of Dogs and Men: Archilochos, Archaeology and the Greek Settlement of Thasos', Proceedings of the Cambridge Philological Society 49, 1-18.

Owen, S. (2005) 'Analogy, Archaeology and Archaic Greek Colonization' in Hurst, H. \& Owen, S. (eds) Ancient Colonizations: Analogy, Similarity and Difference, London: Duckworth, 5-22.

Parke, H. W. \& Wormell, D. E. W. (1956) The Delphic Oracle: Volume 1, The History, Oxford: Basil Blackwell.

Pashkevich, G. A. (2001) 'Archaeobotanical Studies on the Northern Coast of the Black Sea', Eurasia Antiqua 7, 511-567.

Pembroke, S. (1970) 'Locres et Tarente: le role des femmes dans la fondation de deux Colonies Grecques', Annales (Economies, Societes, Civilisations) 25 (5), 1240-1270.

Petersen, J. H. (2010) Cultural Interaction and Social Strategies on the Pontic Shores: Burial Customs in the Northern Black Sea Area c. 550-270 BC, Aarhus: Aarhus University Press.

Petropoulos, E. K. (2005) Hellenistic Colonization in Euxeinos Pontos: Penetration, Early Establishment and the Problem of the 'Emporion' Revisited, BAR International Series 1394, Oxford: Archaeopress.

Polanyi, K. (1963) 'Ports of Trade in Early Societies', Journal of Economic History 23 (1), 30-45.

Pomeroy, S. (1995) Goddesses, Whores, Wives, and Slaves, New York: Schocken Books.

Pomey, P. (1996) 'Navigation and Ships in the Age of Greek Colonization' in Pugliese Carratelli, G. (ed) The Western Greeks. Classical Civilization in the Western Mediterranean, London: Thames \& Hudson, 133-140.

Popham, M. (1987) 'An Early Euboean Ship', Oxford Journal of Archaeology 6, 353-359.

Pugliese Carratelli, G. (ed) (1996) The Western Greeks. Classical Civilization in the Western Mediterranean, London: Thames \& Hudson.

Redfield, J. M. (2003) The Locrian Maidens: Love and Death in Greek Italy, New Jersey: Princeton University Press. 
Ridgway, D. (1973) 'The First Western Greeks: Campanian Coasts and Southern Etruria' in Hawkes, C. \& S. (eds) Greeks, Celts and Romans: Studies in Venture and Resistance, New Jersey: Rowman and Littlefield, 5-38.

Ridgway, D. (1990) 'The First Western Greeks and their Neighbours, 1935-1985' in Descoeudres, J. P. (ed) Greek Colonists and Native Populations, Oxford: Oxford University Press, 61-72.

Ridgway, D. (1981) 'The Foundation of Pithekoussai' in Nouvelle contribution a l'etude de la societe et de la colonisation Eubeennes, Naples: Cahiers du centre Jean Berard, 45-60.

Ridgway, D. (1992) The First Western Greeks, Cambridge: Cambridge University Press.

Rihll, T. (1993) 'War, Slavery, and Settlement in Early Greece' in Rich, J. \& Shipley, G. (eds) War and Society in the Greek World, London: Routledge, 77-107.

Roebuck, C. (1959) Ionian Trade and Colonization, New York: Archaeological Institute of America.

Rosenbaum, E. (1960) A Catalogue of Cyrenaican Portrait Sculpture, London: Oxford University Press.

Rouge, J. (1970) 'La Colonisation Grecque et les Femmes', Cahiers d'histoire 15, 307-317.

Rutter, K. (1986) 'Sicily and South Italy: The Background to Thucydides Books 6 and 7', Greece \& Rome 33 (2), 142-155.

Rutter, N. K. (2002) 'Syracusan Democracy: Most like the Athenian?' in Brock, R. \& Hodkinson, S. (eds) Alternatives to Athens, Oxford: Oxford University Press, 137-151.

Sallares, R. (1991) The Ecology of the Ancient Greek World, New York: Cornell University Press.

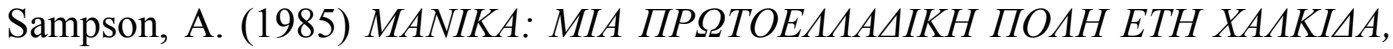
Athens: Society for Euboean Studies.

Schaps, D. M. (1979) Economic Rights of Women in Ancient Greece, Edinburgh: Edinburgh University Press.

Scheidel, W. (2003) 'The Greek Demographic Expansion: Models and Comparisons', Journal of Hellenic Studies 123, 122-40. 
Schutkowski, H. (1993) 'Sex Determination of Infant and Juvenile Skeletons: I. Morphognostic Features', American Journal of Physical Anthropology 90, 199-205.

Serrati, J. (2000) 'Sicily from Pre-Greek Times to the Fourth Century' in Smith, C. \& Serrati, J. (eds) Sicily from Aeneas to Augustus: New Approaches in Archaeology and History, Edinburgh: Edinburgh University Press, 9-14.

Seyrig, H. (1927) 'Quatre Cultes de Thasos', Bulletin de Correspondance Hellenique 51, 178-233.

Shefton, B. B. (1994) 'Massalia and Colonization in the North-Western Mediterranean' in Tsetskhladze, G. R \& de Angelis, F (eds) The Archaeology of Greek Colonisation, Oxford: Oxford University Committee for Archaeology, 61-86.

Shepherd, G. (1995) 'The Pride of Most Colonials: Burial and Religion in the Sicilian Colonies', Acta Hyperborea 6, 51-82.

Shepherd, G. (1999) 'Fibulae and Females: Intermarriage in the Western Greek Colonies and the Evidence from Cemeteries' in Tsetskhladze, G. R. (ed) Ancient Greeks West and East, Leiden: Brill, 267-300.

Shepherd, G. (2000) 'Greeks Bearing Gifts: Religious Relationships Between Sicily and Greece in the Archaic Period', in Smith, C. \& Serrati, J. (eds) Sicily from Aeneas to Augustus: New Approaches in Archaeology and History, Edinburgh: Edinburgh University Press, 55-70.

Shepherd, G. (2005) 'Dead Men Tell No Tales: Ethnic Diversity in Sicilian Colonies and the Evidence of the Cemeteries', Oxford Journal of Archaeology 24 (2), 115-136.

Shepherd, G. (2012) 'Women in Magna Graecia' in James, S. L. \& Dillon, S. (eds) A Companion to Women in the Ancient World, West Sussex: Blackwell Publishing, 215-228.

Shilik, K. K. (1997) 'Oscillations of the Black Sea and Ancient Landscapes' in Chapman, J. \& Dolukhanov, P. (eds) (1997) Landscapes in Flux: Central and Eastern Europe in Antiquity, Oxford: Oxbow Books, 115-129.

Sissa, G. (1990) Greek Virginity, Massachusetts: Harvard University Press.

Sjoqvist, E. (1958) 'Excavations at Serra Orlando (Morgantina): Preliminary Report II', Americal Journal of Archaeology 62 (2), 155-164.

Sjoqvist, E. (1973) Sicily and the Greeks: Studies in the Interrelationship Between the Indigenous Populations and the Greek Colonists, Ann Arbor: The University of Michigan Press. 
Snodgrass, A. M. (1971) The Dark Age of Greece, Edinburgh: Edinburgh University Press.

Snodgrass, A. M. (1980) Archaic Greece: The Age of Experiment, California: University of California Press.

Snodgrass, A. M. (1994) 'The Nature and Standing of the Early Western Colonies' in Tsetskhladze, G. \& De Angelis, F. (eds) The Archaeology of Greek Colonisation, Oxford: Oxford University Committee for Archaeology.

Snodgrass, A. M. (2005) "Lesser Breeds": The History of a False Analogy' in Hurst, H. \& Owen, S. (eds) Ancient Colonizations: Analogy, Similarity and Difference, London: Duckworth, 45-58.

Solovyov, S. L. (1998) 'Archaic Berezan: Historical - Archaeological Essay' in Tsetskhladze, G. R. (ed) Greek Colonisation of the Black Sea Area, Stuttgart: Steiner, 205-225.

Solovyov, S. L. (1999) Ancient Berezan: The Architecture, History and Culture of the First Greek Colony in the Northern Black Sea, Leiden: Brill.

Solovyov, S. L. (2001) 'The Archaeological Excavation of the Berezan Settlement (1987-1991)' in Tsetskhladze, G. R. (ed) North Pontic Archaeology: Recent Discoveries and Studies, Leiden: Brill, 117-141.

Stucchi, S. (1989) 'Problems Concerning the Coming of the Greeks to Cyrenaica and the Relations with their Neighbours', Meditarch 2, 73-84.

Toms, J. (2000) 'The Arch Fibula in Early Iron Age Italy' in Ridgway, D., Ridgway, F. R. S., Pearce, M., Herring, E., Whitehouse, R. D. \& Wilkins, J. B. (eds) Ancient Italy in its Mediterranean Setting, London: Accordia Research Centre, 91-116.

Tsakirgis, B. (1995) 'Morgantina: A Greek Town in Central Sicily', Acta Hyperborea 6, 123-147.

Tsetskhladze, G. R. (1994) 'Greek Penetration of the Black Sea' in Tsetskhladze, G. R \& de Angelis, F (eds) The Archaeology of Greek Colonisation, Oxford: Oxford University Committee for Archaeology, 111-135.

Tsetskhladze, G. R. (1995) 'Did the Greeks go to Colchis for Metals?', Oxford Journal of Archaeology 14 (3), 307-331.

Tsetskhladze, G. R. (1997) 'How Greek Colonists Adapted Their Way of Life to the Conditions in Kolkhis' in Fossey, J. M. (ed) Proceedings of the First International Conference on the Archaeology and History of the Black Sea, Amsterdam: J. C. Gieben, 121-136. 
Tsetskhladze, G. R. (ed) (1998a) Greek Colonisation of the Black Sea Area, Stuttgart: Steiner.

Tsetskhladze, G. R. (1998b) 'Greek Colonisation of the Black Sea Area: Stages, Models, and Native Population' in Tsetskhladze, G. R. (ed) Greek Colonisation of the Black Sea Area, Stuttgart: Steiner, 9-68.

Tsetskhladze, G. R. (ed) (1999) Ancient Greeks West and East, Leiden: Brill.

Tsetskhladze, G. R. (ed) (2001) North Pontic Archaeology: Recent Discoveries and Studies, Leiden: Brill.

Tsetskhladze, G. R. (2002) 'Ionians Abroad' in Tsetskhladze, G. R. \& Snodgrass, A. M. (eds) Greek Settlements in the Eastern Mediterranean and the Black Sea. BAR International Series 1062, Oxford: Archaeopress, 81-96.

Tsetskhladze, G. R. (ed) (2006a) Greek Colonisation: An Account of Greek Colonies and Other Settlements Overseas. Volume One, Leiden: Brill.

Tsetskhladze, G. R. (ed) (2006b) Greek Colonisation: An Account of Greek Colonies and Other Settlements Overseas. Volume Two, Leiden: Brill.

Tsetskhladze, G. R. (2006c) 'Introduction: Revisiting Ancient Greek Colonisation' in Tsetskhladze, G. R. (ed) Greek Colonisation: An Account of Greek Colonies and Other Settlements Overseas. Volume One, Leiden: Brill, xxiii-lxxxiii.

Tsetskhladze, G. R. \& De Angelis, F. (eds) (1994) The Archaeology of Greek Colonisation, Oxford: Oxford University Committee for Archaeology.

Tsetskhladze, G. R. \& Snodgrass, A. M. (eds) (2002) Greek Settlements in the Eastern Mediterranean and the Black Sea. BAR International Series 1062, Oxford: Archaeopress.

Tsetskhladze, G. R. \& Treister, M. Y. (1995) 'The Metallurgy and Production of Precious Metals in Colchis Before and After the Arrival of the Ionians (Towards the Problem of the Reason for Greek Colonisation)', Bulletin of the Metals Museum 24, 1-32.

Tuplin, C. (1999) 'Greek Racism? Observations on the Character and Limits of Greek Ethnic Prejudice' in Tsetskhladze, G. R. (ed) Ancient Greeks West and East, Leiden: Brill, 47-76.

Tuplin, C. (ed) (2003) Pontus and the Outside World: Studies in Black Sea History, Historiography, and Archaeology, Leiden: Brill. 
Van Compernolle, R. (1983) 'Femmes indigenes et colonisateurs' in Modes de Contacts et Processus de Transformation dans les Societes Anciennes, Rome: 1'Ecole Francaise de Rome, 1033-1049.

Van Dommelen, P. (1997) 'Colonial Constructs: Colonialism and Archaeology in the Mediterranean', World Archaeology 28 (3), 305-323.

Van Dommelen, P. (2002) 'Ambiguous Matters: Colonialism and Local Identities in Punic Sardinia' in Lyons and Papadopoulos (eds) The Archaeology of Colonialism, Los Angeles: Getty Research Institute, 121-147.

Van Gennep, A. (1960) The Rites of Passage, London: Routledge \& Kegan Paul, trans Vizedom, M. B. \& Caffee, G. L.

Van Wees, H. (2004) Greek Warfare: Myths and Realities, London: Gerald Duckworth \& Co Ltd.

Waldbaum, J. C. (1997). 'Greeks in the East or Greeks and the East?: Problems in the Definition and Recognition of Presence', Bulletin of the American Schools of Oriental Research 305, 1-17.

Walker, P. L. \& Cook, D. C. (1998) 'Gender and Sex: Vive La Difference!', American Journal of Anthropology 106, 255-259.

Wallinga, H. T. (1993) Ships and Sea-Power Before the Great Persian War, Leiden: Brill.

Wanis, S. (1992) 'A New Relief from Cyrene with a Libyan Scene' Libyan Studies 23, 41-44.

Waters, K. H. (1974) 'The Rise and Decline of Some Greek Colonies in Sicily', Ancient Society 5, 1-19.

Watkins, C. (1976) 'Observations on the "Nestor's Cup" Inscription', Harvard Studies in Classical Philology 80, 25-40.

Weaver, D. S. (1980) 'Sex Differences in the Ilia of a Known Sex and Age Sample of Fetal and Infant Skeletons', American Journal of Physical Anthropology 52, 191-195.

West, S. (2007) 'Herodotus and Olbia' in Braund, D. \& Kryzhitskii, S. D. (eds) Classical Olbia and the Scythian World: From the Sixth Century BC to the Second Century AD, Oxford: Oxford University Press, 79-92.

White, D. (1987) 'Demeter Libyssa: Her Cult in Light of the Recent Excavations', Quaderni di archeologia della Libia 12, 67-84.

White, T. D. \& Folkens, P. A. (2005) The Human Bone Manual, Massachusetts: Elsevier Academic Press. 
Whitehouse, R. \& Wilkins, J. B. (1989) 'Greeks and Natives in Southeast Italy: Approaches to the Archaeological Evidence' in Champion, T. C. (ed) Centre and Periphery: Comparative Studies in Archaeology, London: Unwin Hyan, 102-126.

Whitley, J. (2001) The Archaeology of Ancient Greece, Cambridge: Cambridge University Press.

Wiedemann, T. E. J. (1983) 'Thucydides, Women and the Limits of Rational Analysis', Greece \& Rome 30 (2), 163-170.

Wilson, J. P. (1997) 'The Nature of Greek Overseas Settlements in the Archaic Period: Emporion or Apoikia?' in Mitchell, L. G. \& Rhodes, P. J. (eds) The Development of the Polis in Archaic Greece, London: Routedge, 199-207

Wilson, J. P. (2006) 'Ideologies' of Greek Colonization' in Bradley, G. \& Wilson, J. P. (eds) Greek and Roman Colonization: Origins, Ideologies, and Interactions, Swansea: The Classical Press of Wales, 25-57.

Wilson, R. J. A. (1981-82) 'Archaeology in Sicily, 1977-1981', Archaeological Reports 28, 84-105.

Wilson, R. J. A. (1987-88) 'Archaeology in Sicily, 1982-87', Archaeological Reports 34, 105-150.

Woodhead, A. G. (1981) The Study of Greek Inscriptions, Cambridge: Cambridge University Press, $2^{\text {nd }}$ ed.

Wylie, A. (1991) 'Gender Theory and the Archaeological Record: Why is There No Archaeology of Gender?' in Gero, J. M. \& Conkey, M. W. (eds) Engendering Archaeology: Women and Prehistory, Oxford: Basil Blackwell, 31-54.

Zeitlin, F. (1986) 'Configurations of Rape in Greek Myth' in Tomaselli, S. \& Porter, R. (eds) Rape, Oxford: Basil Blackwell, 122-151. 